\title{
An atlas of larval organogenesis in the European shore crab Carcinus maenas L. (Decapoda, Brachyura, Portunidae)
}

Franziska Spitzner ${ }^{1,2}$, Rebecca Meth ${ }^{1,2}$, Christina Krüger ${ }^{1}$, Emanuel Nischik', Stefan Eiler ${ }^{1,3}$, Andy Sombke ${ }^{1}$, Gabriela Torres ${ }^{2+}$ and Steffen Harzsch ${ }^{1 *+}$ (D)

\begin{abstract}
Background: The life history stages of brachyuran crustaceans include pelagic larvae of the Zoea type which grow by a series of moults from one instar to the next. Zoeae actively feed and possess a wide range of organ systems necessary for autonomously developing in the plankton. They also display a rich behavioural repertoire that allows for responses to variations in environmental key factors such as light, hydrostatic pressure, tidal currents, and temperature. Brachyuran larvae have served as distinguished models in the field of Ecological Developmental Biology fostering our understanding of diverse ecophysiological aspects such as phenotypic plasticity, carry-over effects on life-history traits, and adaptive mechanisms that enhance tolerance to fluctuations in environmental abiotic factors. In order to link such studies to the level of tissues and organs, this report analyses the internal anatomy of laboratory-reared larvae of the European shore crab Carcinus maenas. This species has a native distribution extending across most European waters and has attracted attention because it has invaded five temperate geographic regions outside of its native range and therefore can serve as a model to analyse thermal tolerance of species affected by rising sea temperatures as an effect of climate change.

Results: Here, we used X-ray micro-computed tomography combined with 3D reconstruction to describe organogenesis in brachyuran larvae. We provide a detailed atlas of the larval internal organization to complement existing descriptions of its external morphology. In a multimethodological approach, we also used cuticular autofluorescence and classical histology to analyse the anatomy of selected organ systems.
\end{abstract}

Conclusions: Much of our fascination for the anatomy of brachyuran larvae stems from the opportunity to observe a complex organism on a single microscopic slide and the realization that the entire decapod crustacean bauplan unfolds from organ anlagen compressed into a miniature organism in the sub-millimetre range. The combination of imaging techniques used in the present study provides novel insights into the bewildering diversity of organ systems that brachyuran larvae possess. Our analysis may serve as a basis for future studies bridging the fields of evolutionary developmental biology and ecological developmental biology.

Keywords: Micro-CT, 3D reconstruction, Osmoregulation, Excretion, Sensory systems, Central nervous system, Metamorphosis, Locomotion

\footnotetext{
* Correspondence: steffen.harzsch@uni-greifswald.de

† Gabriela Torres and Steffen Harzsch contributed equally to this work.

${ }^{1}$ Zoological Institute and Museum, Department of Cytology and Evolutionary

Biology, Universität Greifswald, D-17498 Greifswald, Germany

Full list of author information is available at the end of the article
}

(C) The Author(s). 2018 Open Access This article is distributed under the terms of the Creative Commons Attribution 4.0 International License (http://creativecommons.org/licenses/by/4.0/), which permits unrestricted use, distribution, and reproduction in any medium, provided you give appropriate credit to the original author(s) and the source, provide a link to the Creative Commons license, and indicate if changes were made. The Creative Commons Public Domain Dedication waiver (http://creativecommons.org/publicdomain/zero/1.0/) applies to the data made available in this article, unless otherwise stated. 


\section{Background}

Brachyuran crustaceans display a complex life cycle that includes a pelagic larval phase and a benthic juvenile-adult phase (reviews [1-7]). The adult females carry eggs, from which in most species larvae hatch that are called zoeae and that subsequently develop in the plankton. Larval development includes a series of moults from one zoea instar to the next (Fig. 1a), and may last for several days up to months. The number of zoea instars varies between species and may change within a species depending on environmental factors. For example, decreased salinity causes a delay in larval development of Neohelice granulata, including an additional zoeal instar [8]. Zoeae actively feed and display a wide array of adaptations for survival in the pelagic environment concerning their morphology, physiology, behaviour and ecology (reviews $[1,3])$. Life in the plankton provides opportunities but also bears risks. Co-occurring plankton organisms provide a rich source of food; however, local and temporal limitations of food availability as well as unsuitable temperatures and salinities represent factors that increase larval mortality (reviews [4, 7]). Furthermore, long periods of growth in the plankton are essential for dispersal and range expansion of brachyuran species and to connect established populations, even if a longer pelagic phase enhances the risk of predation.

Zoeae are known to possess a wide range of organ systems necessary for autonomously surviving and developing in the plankton (Tab. 1) including a sophisticated digestive system, osmoregulatory organs, a well-developed neuromuscular system and a range of sensory organs to detect environmental cues (e.g. light, gravity, temperature, chemical stimuli). They also display a rich behavioural repertoire that allows for responses to variations in environmental key factors: light, hydrostatic pressure, tidal currents, temperature, salinity, and food concentration (reviews [7, 9, 10]). For example, zoeae can control their position within the water column and, by distinct vertical migration behaviour, use tidal currents for offshore transport (reviews [7, 11, 12]). In addition, they use perceived chemical cues from their conspecifics to identify suitable habitats to metamorphose and recruit (reviews $[4,7,9,10$, 13]). For many decades, brachyuran larvae have served as distinguished models in the field of Ecological Developmental Biology (EcoDevo; reviews [4, 7]). Laboratory and field studies on the development of brachyuran larvae have fostered our understanding of diverse ecophysiological aspects such as phenotypic plasticity in developmental traits, heterochrony in developmental patterns, carry-over effects on life-history traits, and adaptive mechanisms that enhance tolerance to fluctuations in environmental abiotic and biotic factors. Furthermore, a diverse range of biological topics has been analysed using brachyuran larvae as models including aspects of the physiology of aquatic-terrestrial and marine-limnic transitions, dispersal potential of invasive species, adaptive significance of abbreviated development, and effects of acclimation (reviews [4, 7]) but also the effects of environmental change-induced abiotic stress on ontogenetic stages of marine organisms [14].

The last zoeal instar of Brachyura metamorphoses into a semi-benthic larva, the Megalopa, the last larval stage in brachyurans (Fig. 1a). This moult is frequently designated as the first metamorphosis. The Megalopa gradually settles on the sea bottom where in a second metamorphosis it moults to an adult-like benthic juvenile. Both metamorphoses are associated with distinct changes in habitat, behaviour, locomotion, feeding, morphology, and ecology (reviews [1, 3-6, 15]). This complex life history involves developmental transformations of the cephalic, thoracic and pleonal appendages as summarized in Fig. 1b. In planktonic zoeae, in addition to handling food items, the first and second maxillipeds also serve a natatory function that is fulfilled by their exopods. During the first metamorphosis, the maxillipeds lose the exopods and with it, their locomotor function and will exclusively serve as part of the feeding apparatus. The pereiopods and pleopods gradually emerge as non-functional embryonic anlagen in the zoeae to become functional for locomotion during the first metamorphosis, corresponding to the requirements of a transition from the pelagic to the benthic life style that takes place during the megalopa stage. The Megalopa of Brachyura can still swim using its pleopods that bear long setae and can use tidal-currents for onshore transport. After the second metamorphosis to the juvenile stage, the organsims become completely benthic and their pleopods lose the natatory function (Fig. 1b) to become part of the reproductive system as copulatory organs and as attachment sites for the extruded mass of fertilized eggs.

The external morphology of brachyuran larvae has been documented for an extraordinarily wide range of species for many decades, using light microscopy and by line drawings (Fig. 1; [1, 2, 5, 16]), as well as scanning electron microscopy [17-20]. Decapod crustacean larvae provide the fascinating opportunity to study the wealth of organ systems of the adult bauplan compressed into a tiny but autonomous organism that fully fits under the microscope. Nevertheless, and despite their outstanding role as models in ecological developmental biology, our current knowledge on the internal anatomy of brachyuran larvae is still rather limited, the most important resources being studies on Cancer anthonyi [21] and Portunus trituberculatus [22]. Other techniques to analyse anatomical aspects of the larvae of decapod crustaceans include for example semi-thin sectioning of resin embedded specimens [23-29], three-dimensional reconstruction of histological 
a

\section{Carcinus maenas}
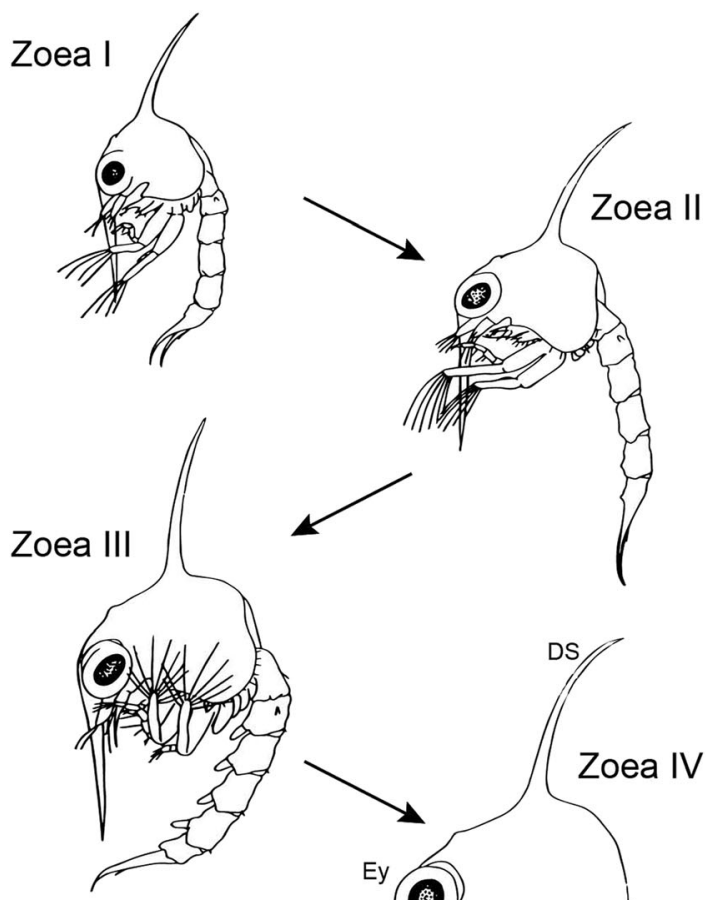

Megalopa
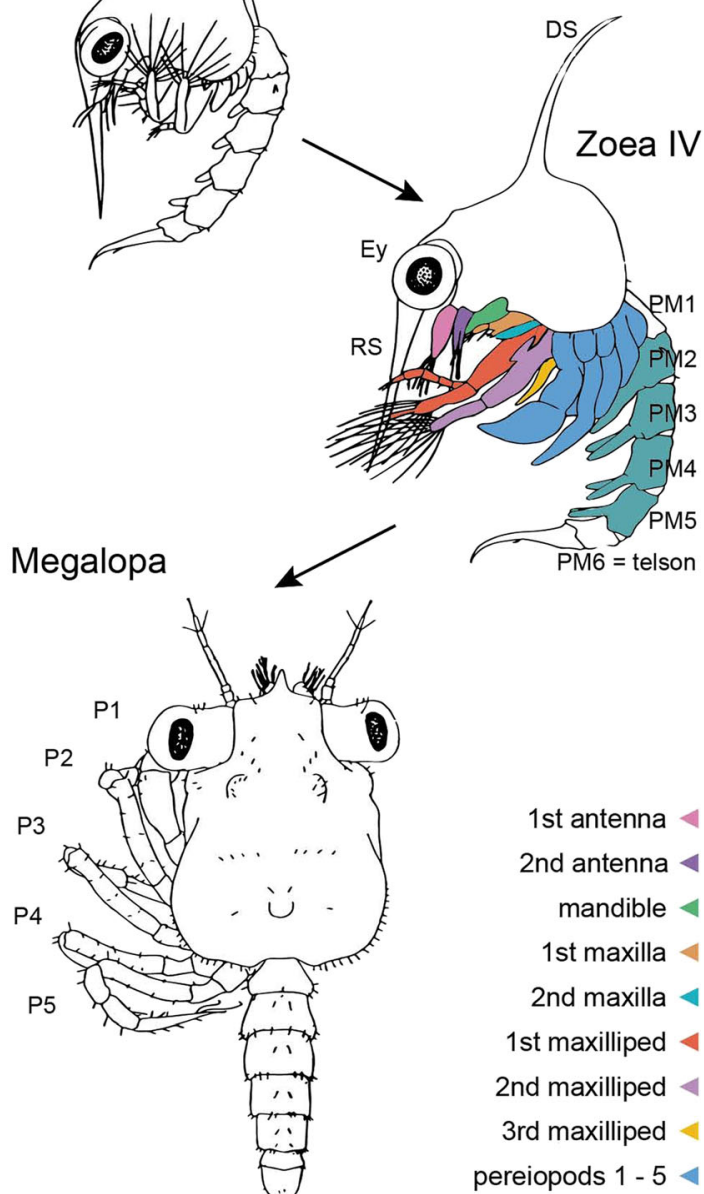

pleomeres 2 - 5 with pleopods $1-4<$ b
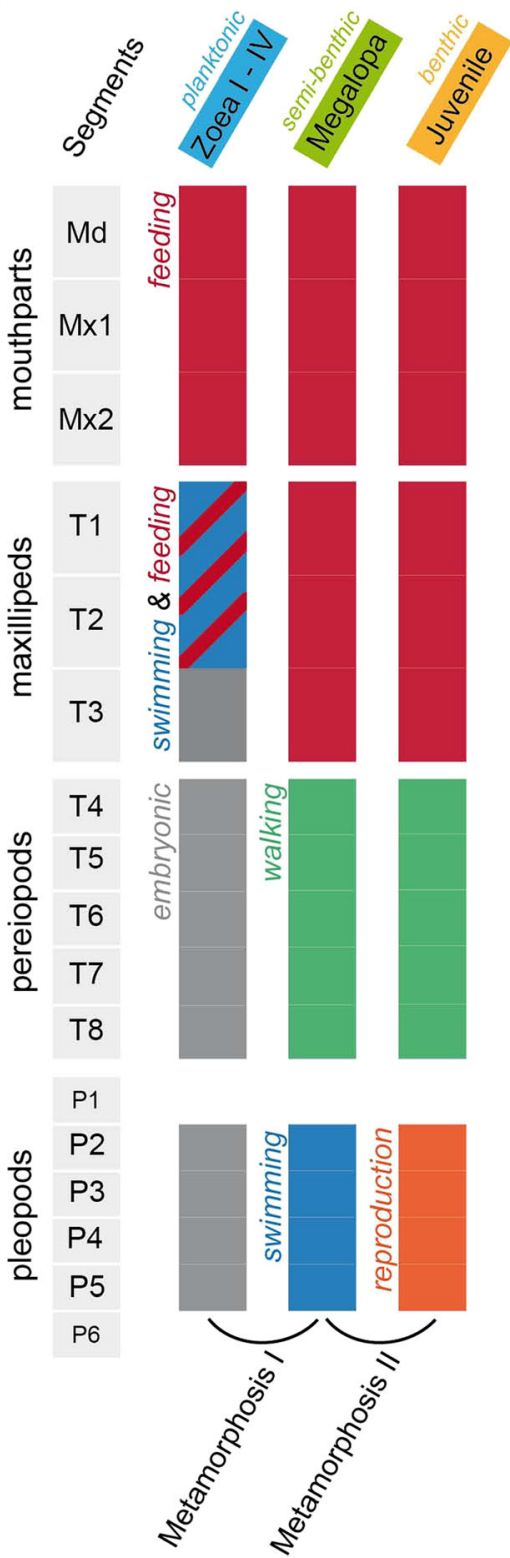

\section{$0,5 \mathrm{~mm}$}

Fig. 1 a - Larval development of Carcinus maenas L. (Decapoda, Brachyura, Portunidae) modified from Rice and Ingle (1975). b - ontogenetic change of appendage function during the double metamorphosis (see text for further details). Abbreviations: Ey - compound eye, DS - dorsal spine, Md - mandibular segment, Mx1, Mx2 - segments of $1^{\text {st }}$ and $2^{\text {nd }}$ maxilla, P1-5 - pereiopod one to five, PM1-6 - pleomeres one to six, RS - rostral spine, T1-8 - thoracomeres one to eight 
Table 1 Studies on larval organogenesis in representatives of Pleocyemata

\begin{tabular}{|c|c|}
\hline \multicolumn{2}{|l|}{ General internal anatomy } \\
\hline Cancer anthonyi & Trask 1974 [21] \\
\hline Portunus trituberculatus & Nakamura 1990 [22] \\
\hline \multicolumn{2}{|l|}{ Mouthparts and digestive tract } \\
\hline Maja brachydactyla & Castejon et al. 2015 [89] \\
\hline Hyas araneus & $\begin{array}{l}\text { Storch and Anger } 1983 \text { [72], } \\
\text { Höcker } 1988 \text { [82] }\end{array}$ \\
\hline Scylla olivacea & Jantrarotai et al. 2005 [137] \\
\hline Scylla serrata & $\begin{array}{l}\text { Li and Li } 1995 \text { [138], } 1998 \text { [139], } \\
\text { Lumasag et al. } 2007 \text { [140] }\end{array}$ \\
\hline Ucides cordatus & Abrunhosa et al. 2003 [91] \\
\hline Dyspanopeus sayi & Castejon et al. 2015 [92] \\
\hline Sesarma curacaoense & Melo et al. 2006 [93] \\
\hline several Brachyura & Geiselbrecht and Melzer 2010 [20] \\
\hline Ranina ranina & Minagawa and Takashima 1994 [88] \\
\hline Menippe mercenaria & Factor 1982 [23] \\
\hline Paralithodes camtschaticus & Abrunhosa and Kittaka 1997 [96] \\
\hline Homarus americanus & $\begin{array}{l}\text { Anger et al. } 1985 \text { [98], Sasaki } \\
\text { et al. } 1986 \text { [141], Factor } 1981 \text { [17], } \\
\text { Biesot and McDowell } 1995 \text { [97] }\end{array}$ \\
\hline Procambarus fallax f. virginalis & Vogt 1994 [71], 2008 [49, 50] \\
\hline Jasus edwardsii & Nishida et al. 1990 [142] \\
\hline Macrobrachium amazonicum & Batel et al. 2014 [143] \\
\hline Palaemon elegans & Batel et al. 2014 [143] \\
\hline \multicolumn{2}{|l|}{ Osmoregulatory epithelia } \\
\hline Carcinus maenas & Cieluch et al. 2004 [43], Hong 1988 [77] \\
\hline Eriocheir sinensis & Cieluch et al. 2007 [44], \\
\hline Callianassa jamaicense & Felder et al. 1986 [144] \\
\hline Astacus leptodactylus & Lignot et al. 2005 [29] \\
\hline several Brachyura and Anomala & Hong 1988 [77] \\
\hline Homarus americanus & Lignot and Charmantier 2001 [31] \\
\hline Palaemontes argentinus & $\begin{array}{l}\text { Leone et al. } 2012 \text { [134], } \\
\text { Ituarte et al. } 2016 \text { [45] }\end{array}$ \\
\hline Litopenaeus stylirostris & Pham et al. 2016 [145] \\
\hline \multicolumn{2}{|l|}{ Antennal glands } \\
\hline Astacus leptodactylus & Khodabandeh et al. $2005[80,81]$ \\
\hline Homarus gammarus & Khodabandeh et al. 2006 [108] \\
\hline Macrobrachium amazonicum & Boudour-Boucheker et al. 2013 [79] \\
\hline Palaemontes argentinus & Ituarte et al. 2016 [45] \\
\hline \multicolumn{2}{|l|}{ Integument and tegumental glands } \\
\hline Hyas araneus & Höcker 1988 [82] \\
\hline Sesarma haematocheir & Ikeda et al. 2004 [32] \\
\hline multiple species & Freemann 1993 [146] \\
\hline \multicolumn{2}{|l|}{ Y organ } \\
\hline Cancer anthonyi & McConaugha 1980 [132] \\
\hline Hyas araneus & Höcker 1988 [82] \\
\hline
\end{tabular}

Table 1 Studies on larval organogenesis in representatives of Pleocyemata (Continued)

Eyestalk neuroendocrine centres

$\begin{array}{ll}\begin{array}{l}\text { Cancer anthonyi } \\ \text { Homarus gammarus } \\ \text { Compound eyes }\end{array} & \text { Rotllant et al. 1994 [26], 1995 [27] } \\ \text { Callinectes sapidus } & \text { Cronin et al. 1995 [147] } \\ \text { Carcinus maenas } & \text { Harzsch and Dawirs 1996 [25] } \\ \text { Hemigrapsus sanguineus } & \text { Charpentier and Cohen 2015 [148] } \\ \text { Rhithropanopeus harrisii } & \text { Charpentier and Cohen 2015 [148] } \\ \text { various Anomala } & \text { Fincham 1988 [149] } \\ \text { Panulirus longipes } & \text { Meyer-Rochow 1975 [150] } \\ \text { Procambarus clarkii } & \text { Hafner and Tokarski 1998 [151] } \\ \text { Aesthetascs } & \\ \text { Carcinus maenas } & \text { Ekerholm and Hallberg 2002 [83] } \\ \text { Cherax destructor } & \text { Sandeman and Sandeman 1990 [152] }\end{array}$

Structure of the CNS and neurogenesis

Carcinus maenas
Hyas araneus
Pachygrapsus marmoratus
Porcellana platycheles
Cherax destructor
Homarus americanus
Hippolyte inermis

Harzsch and Dawirs 1993 [24]

Harzsch and Dawirs 1994 [36], 1995 [41], Harzsch et al. 1998 [38]

Geiselbrecht and Melzer 2013 [30]

Geiselbrecht and Melzer 2013 [30]

Sullivan and MacMillan 2001 [40]

Helluy et al. 1995 [28], Harzsch et al. 1998 [38]

Immunolocalization of neuroactive substances in the CNS

Carcinus maenas

moult inhibiting hormone, Webster and Dircksen 1991 [130], crustacean cardioactive peptide, Chung and Webster 2004 [131] crustacean hyperglycemic hormone

Hyas araneus

$\begin{array}{ll}\text { serotonin } & \text { Harzsch and Dawirs } 1995 \text { [41] } \\ \text { RFamide } & \text { Harzsch and Dawirs } 1996 \text { [42] }\end{array}$

Astacus leptodactylus crustacean hyperglycemic Gorgels-Kallen and Meij 1985 [153] hormone

Cherax destructor serotonin Sandeman and Sandeman 1990 [152], Helluy et al. 1993 [154]

GABA, glutamate

Foa and Cooke 1998 [155]

Homarus americanus

serotonin

Beltz et al. 1990 [156], 1992 [157],

Helluy et al. 1993 [154],

Harzsch 2003b [158]

proctolin

Beltz et al. 1990 [156], 1992 [157]

dopamine

Cournil et al. 1995 [159]

octopamine

Schneider et al. 1996 [160] 
Table 1 Studies on larval organogenesis in representatives of Pleocyemata (Continued)

\begin{tabular}{ll}
\hline $\begin{array}{l}\text { nitric oxide/cyclic guanosine } \\
\text { mono-phosphate } \\
\text { pigment dispersing hormone } \\
\text { various neuropeptides }\end{array}$ & $\begin{array}{l}\text { Scholz et al. 1998 [161], } \\
\text { Benton et al. 2007 [162] } \\
\text { Homarus gammarus } \\
\text { gonad-inhibiting hormone }\end{array}$ \\
$\begin{array}{l}\text { Procambarus fallax f. virginalis } 2009 \text { [163] } \\
\text { serotonin } \\
\text { histamine }\end{array}$ & Rotllant et al. 1993 [165], 1995 [27] \\
\hline
\end{tabular}

data [30], transmission electron microscopy [26, 31-34], DiI labelling combined with confocal laser-scan microscopy [35], in vivo incubation with mitosis markers [36-39], nuclear labelling with a DNA markers [40]) and immunohistochemical localization of neuronal antigens $[41,42]$ and ion pumps within transport epithelia [43-45]. Table 1 summarizes studies on the anatomy of developing organ systems, limited to representatives of the Pleocyemata, but including studies that synthesize data on the transition from embryos to larvae. Furthermore, aspects of early embryogenesis in decapod crustaceans have been summarized in a number of contributions [46-56] and will not be further discussed here.

This study sets out to provide a comprehensive overview of the internal anatomy of brachyuran larvae. We selected laboratory-reared larvae of the European shore crab Carcinus maenas L. (Decapoda, Brachyura, Portunidae), a species that has a native distribution extending across most European waters from Norway to Mauritania [57]. This species has attracted attention because it has invaded five temperate geographic regions outside of its native range [58] and can serve as a model to analyse thermal tolerance of species impacted by rising sea temperatures as an effect of climate change [59]. The external morphology of $C$. maenas larvae, including the larval appendages, has already been thoroughly documented $[60,61]$. They can be reared under controlled conditions in the laboratory [62, 63], an essential requirement for an animal to serve as a model in developmental biology. Consequently, larval elemental composition, respiration rates and energy balances have been analysed during development under optimal conditions for this species ([64]), and multiple factors that affect larval growth and feeding rates, such as temperature and food availability have been examined [65-68]. Here, for the first time, we use X-ray micro-computed tomography combined with $3 \mathrm{D}$ reconstruction to describe organogenesis from the first to the last larval stage in this species. Classical histology was used to analyse the anatomy of selected organ systems. We aimed to provide a detailed atlas of the larval internal organization to complement the existing descriptions of the external morphology. Our analysis may serve as a basis for future studies bridging the fields of Evolutionary Developmental Biology and Ecological Developmental Biology.

\section{Results}

\section{External Morphology}

As is typical of all portunid zoeae, the cephalothorax of the C. maenas Zoea IV is armed with a characteristic rostral and a dorsal spine (Fig. 2a; and [60, 61]). In the Zoea I, the compound eyes are sessile, but after moulting to the Zoea II they are stalked. In bright field and epifluorescence images, chromatophores embedded within the epidermis can be clearly seen, most prominently at the lateral carapace, the proximal podomeres of maxillipeds, and sometimes also in the pleon (Fig. 2a). The functional cephalic appendages of all zoeal stages comprise the first and second antennae as well as the mouthparts, which include the well-developed and strongly calcified mandibles, followed by the first and second pair of maxillae (Fig. 2b). In the zoeal stages, the first and second maxillipeds display well-developed exopods with long setae at their distal tips, in addition to the endopods (Fig. 2b). The third maxillipeds are not yet functional at hatching but gradually form in the Zoea III and IV where they become visible as conspicuous tissue buds. The anlagen of the thoracic limbs of thoracomere four to eight, the pereiopods, also emerge as small tissue buds in the Zoea II and they continue to grow during the Zoea III. In the Zoea IV, individual podomeres can be distinguished and the first pereiopod (thoracomere four) already displays the propodus and the dactylus of the chela (Fig. 1b). The last segment of the pleon, the telson, in the Zoea IV bears the elongated spine-like uropods and distinct pleopod anlagen are visible on pleomeres number two to five (Figs. 2a, 3). The pleopod anlagen emerge as small buds in the Zoea II and become fully functional in the Megalopa (Fig. 3). Many morphological features of the zoea stages I to IV remain unchanged but the larvae increase in size (Fig. 3). On the contrary, the first metamorphic moult to the Megalopa coincides with major transformations in morphology. The cephalothorax attains the typical adult crab habitus (Fig. 3) and the Megalopa looses the dorsal spine completely, but a small tapered rostrum remains.

\section{Digestive System}

As in adult Brachyura, the digestive tract of all larval stages of $C$. maenas consists of three sections (green in Figs. 3, 4 and 5): the oesophagus (Eso) that connects to the two-chambered foregut (FG; also called proventriculus), the midgut (MG), and the hindgut (HG). The 

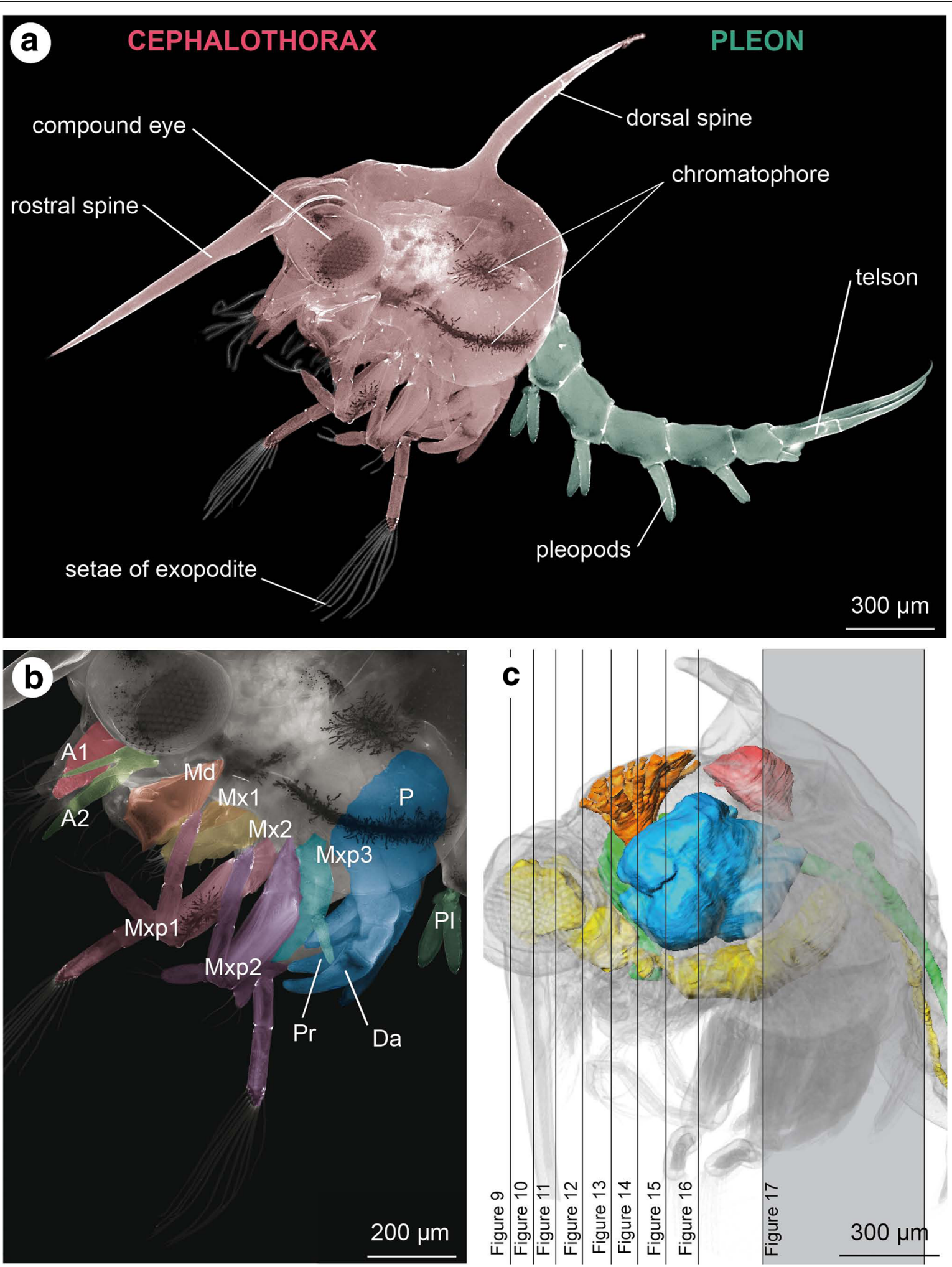

Fig. 2 a - lateral view of a Zoea IV (autofluorescence of cuticle). b - higher magnification of specimen in A showing cephalic and thoracic appendages, the colour code corresponds to Fig. 1A. c: Zoea IV, 3D-reconstruction of selected organs (colour code see Fig. 3) to indicate the sectioning planes shown in Figs. 9, 10, 11, 12, 13, 14, 15, 16 and 17. Abbreviations: A1 - first antenna, A2 - second antenna, Da - dactylus of the first pereiopod (chela), Md - mandible, Mx1 - first maxilla, M×2 - second maxilla, Mxp1 - first maxilliped, Mxp2 - second maxilliped, Mxp3 - third maxilliped, P - pereiopod anlagen, PI - pleopod anlagen, $\mathrm{Pr}$ - Propodus of the first pereiopod (chela) 


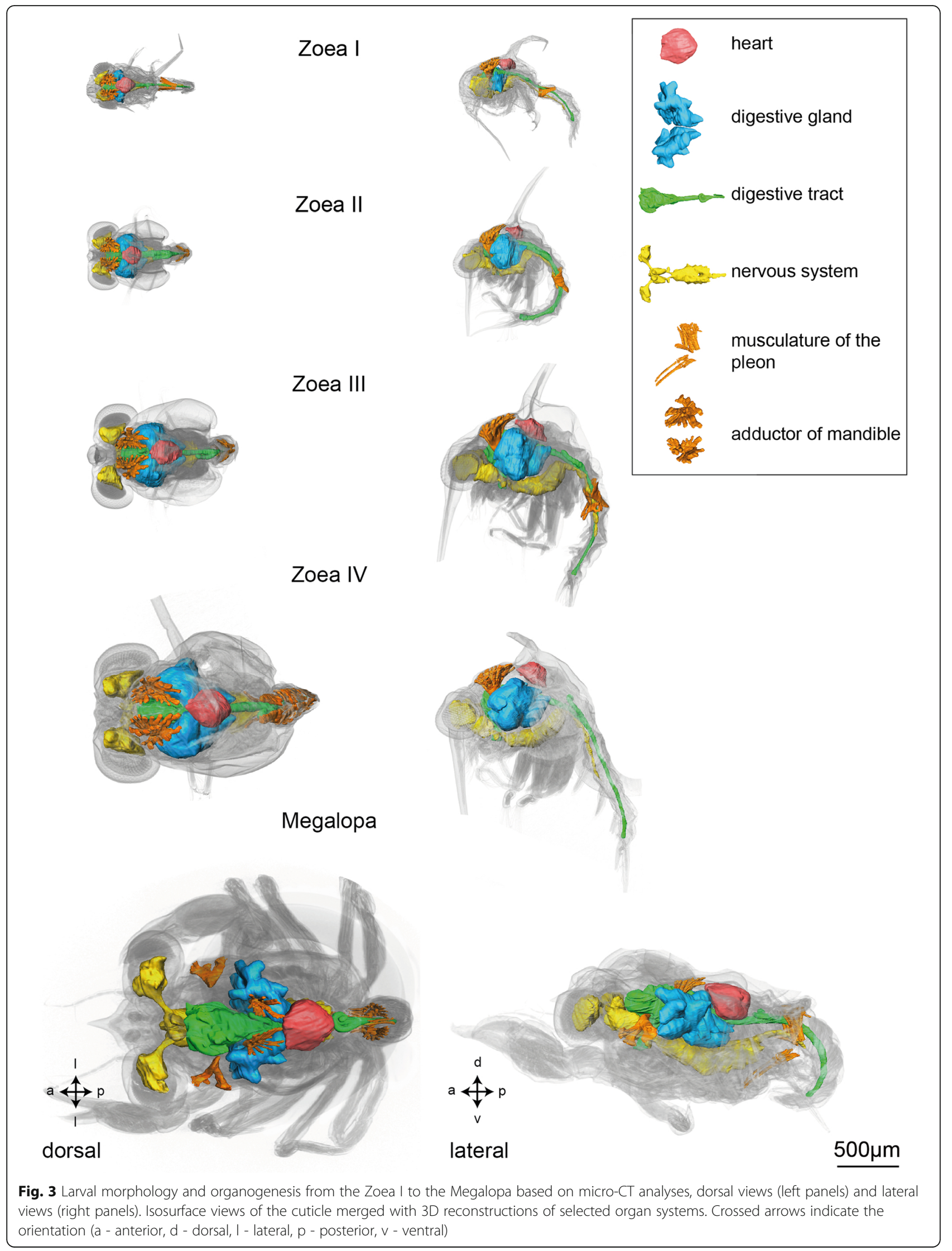




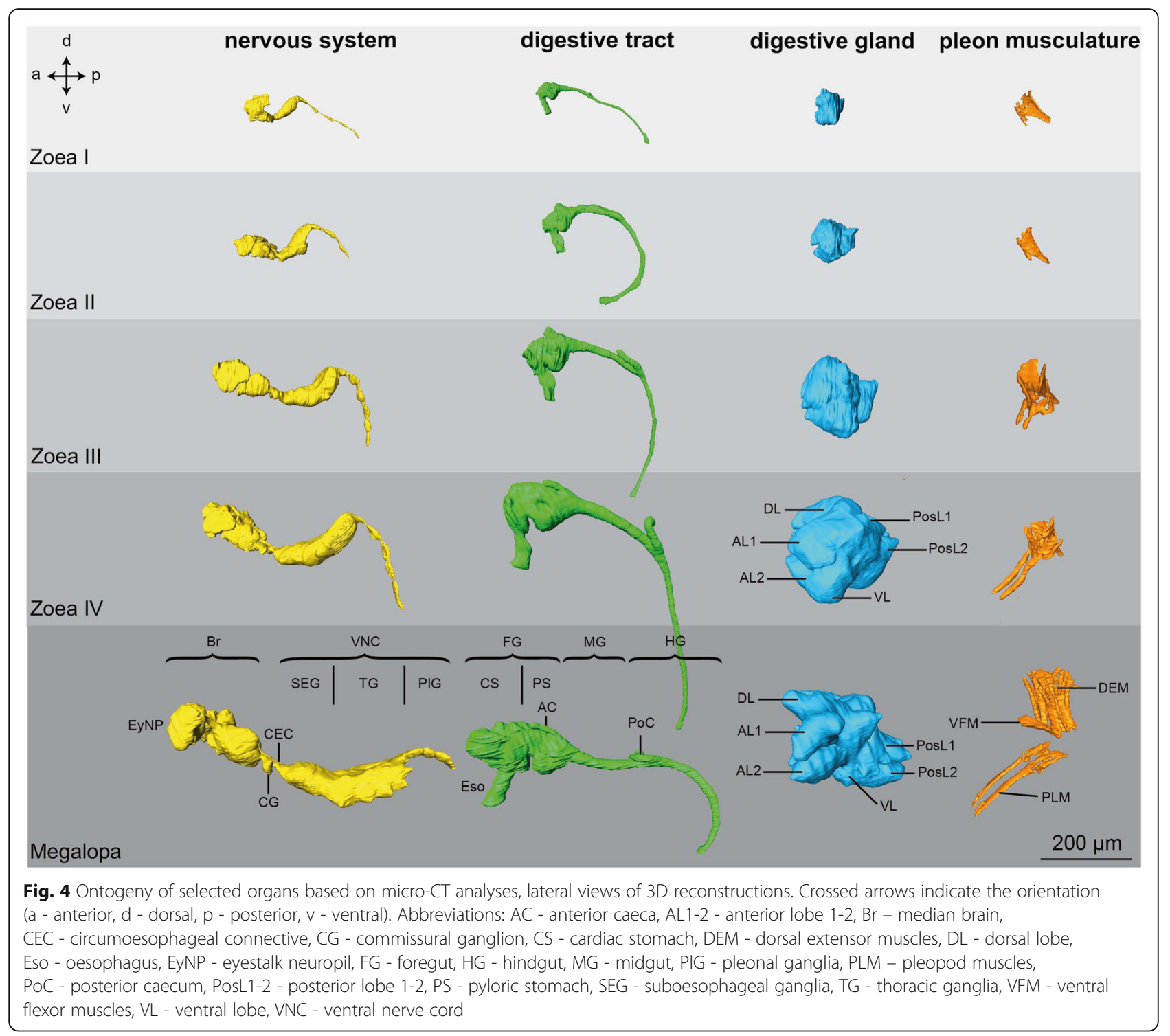

function of mechanically grinding the food is shared between the mandibles and the gastric mill of the foregut whereas digestion and absorption primarily occur within the midgut. In the following, we will describe the elemts of the degestive system based on the histological section series of a Zoea IV (Figs. 6, 7, 8, 9, 10, 11, 12, 13, 14, 15, 16 and 17).

\section{Mandibles and foregut in the Zoea IV}

The larval mouth is flanked by the pair of mandibles (Md, Fig. 14a). In frontal views of the Zoea IV, the molar process (MP) with its massive cuticle $(\mathrm{Cu})$ and incisor process (IP) of the mandible can be distinguished (Fig. 14d). The anlage of the mandibular palp (MdP) has its origin in a dense, spherical accumulation of cells within the mandible from where this structure projects posteriorly and extends in parallel to the mandible (Fig. 12b, e, e', 13).
The tubular oesophagus (Eso) is composed of a multicellular epithelium and extends dorsally from the mouth (Figs. 13a, 14a, e). The inner side of the oesophagus is lined with a thin layer of cuticle showing its ectodermal origin (Fig. 14e). Distinct bundles of dilatator muscles (DMsc; Fig. 14d, e) are laterally attached to the oesophagus just dorsal to the mouth opening, possibly mediating peristaltic movements of the oesophagus. The oesophagus opens dorsally into the cardiac stomach (CS; also called anterior proventriculus) which forms the large anterior part of the foregut (Figs. 4, 7c, 12b, 13a). The cardiac stomach comprises the large cardiac sac (CSac), and the gastric mill composed of two lateral and one median teeth covered with thick cuticle (Fig. 13b). It is laterally flanked by distinct stands of striated muscle (CMsc, Fig. 13b) that may serve to contract the cardiac stomach. Paired muscle strands suspend the foregut to the integument dorsally (dorsal gastric 


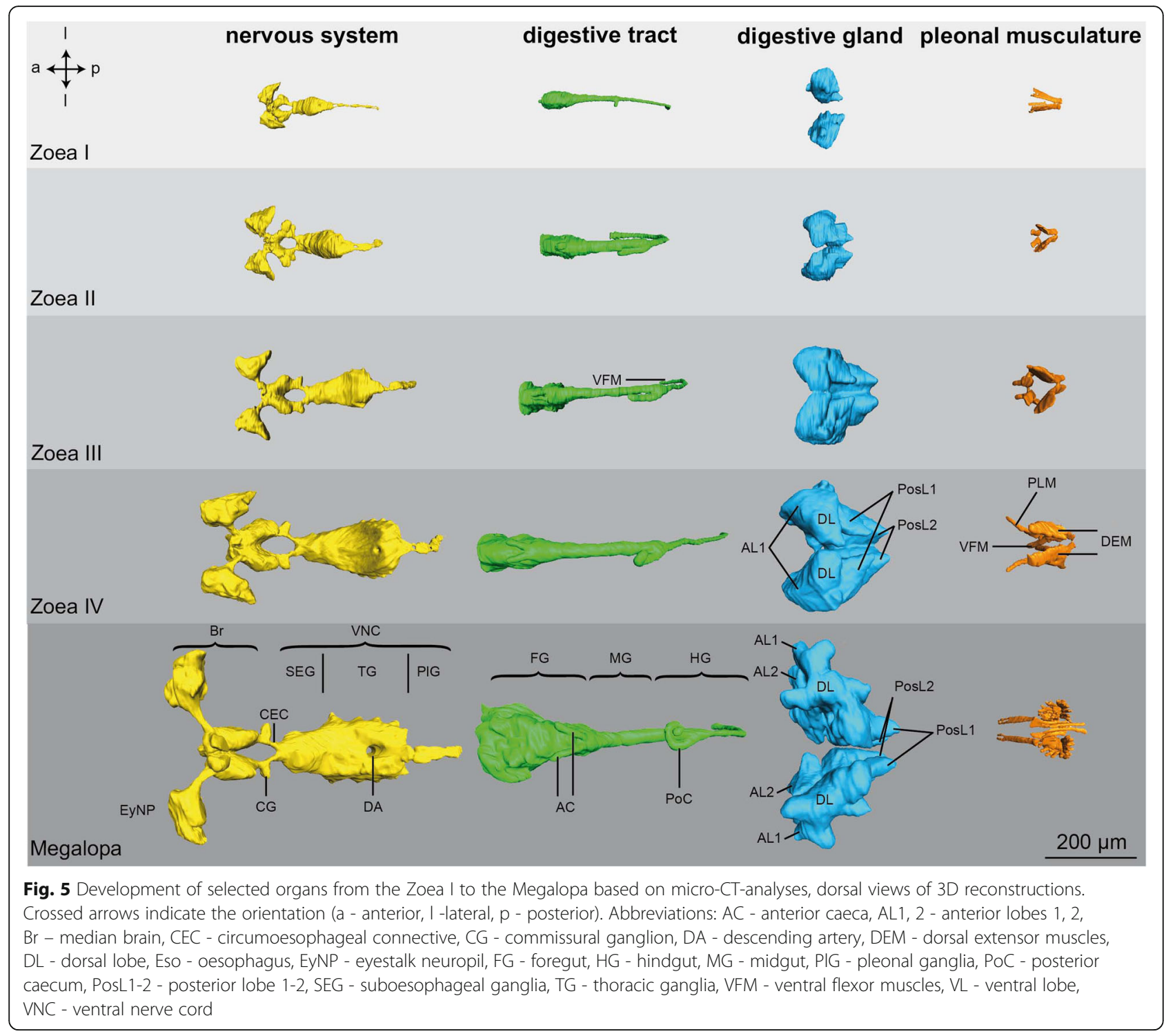

muscles: DGM, Fig. 13a), anteriorly (anterior gastric muscles: AGM, Figs. 10i, 11a), and ventrally (ventral gastric muscles: VGM, Fig. 14b).

The cardiac stomach is separated from the adjoining, more ventrally arranged pyloric stomach (PS; Figs. 4, 6c, 7c, 15a; also called posterior proventriculus) by a slight constriction, the cardio-pyloric valve (CV; Fig. 7c). The pyloric stomach is composed of a dorsal region, the pyloric chamber (DPC) and a ventral region, the ampullary chamber (UAC and LAC; Fig. 14c). These chambers are separated from each other by a pair of prepyloric ossicles (PPO). The ventral ampullary chamber represents a complex filter system, the filter press (FP; also called gland filter; Figs. 14c, 17a), which prevents large particles from passing to the most ventral part of the pyloric chamber. The lateral sides of this ventral portion of the pyloric stomach are lined by setae. The median interampullary ridge (IAR) is also covered with ampullary setae (ASS) at its lateral sides. Liquid food components pass the filter press to reach the digestive gland.

\section{Midgut and digestive gland in the Zoea IV}

The midgut connects posteriorly to the dorsal region of the pyloric stomach (green in Fig. 7; see also Figs. 10e, 17b). At the junction between these two regions, the paired, anteriorly directed midgut caeca (AC) are attached dorsally (Figs. 4, 7e, 14a, 15a). The caeca end blindly and consist of a single layer of epithelial cells without visible specialization. The midgut itself is also composed of a single layer of columnar epithelial cells (Fig. 16b). The paired lobes of the digestive gland (DG) are connected to the ventral ampullary chamber and the filter press (Figs. 16a, b). Posteriorly to this interface 


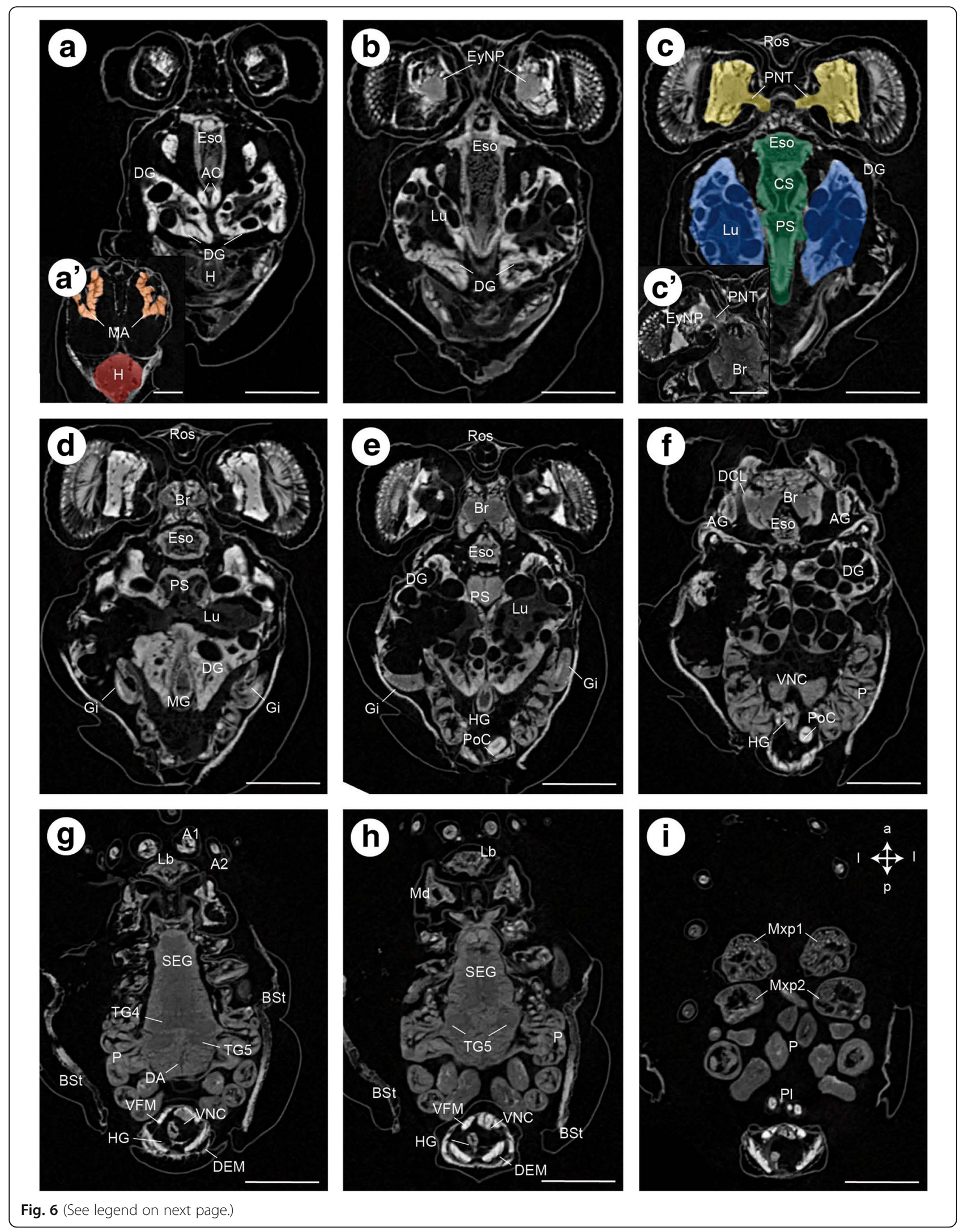


(See figure on previous page.)

Fig. 6 Zoea IV, consecutive horizontal sections from micro-CT analysis, from dorsal (a) to ventral (i). In a and $\mathbf{c}$, the organs are coloured according to code used in Fig. 5. Crossed arrows in I indicate the orientation (a - anterior, I -lateral, p - posterior). Abbreviations: A1 - first antenna, A2 second antenna, AC - anterior caecum, AG - antennal gland, Br - median brain, Bst - epithelium of the branchiostegite, CS - cardiac stomach, DA - descending artery, DCL - deutocerebral chemosensory lobe, DEM - dorsal extensor muscle, DG - digestive gland, Eso - oesophagus, EyNP eyestalk neuropil, Gi - gill, H - heart, HG - hindgut, Lb - labrum, Lu - lumen, MA - mandibular adductor musculature, Md - mandible, Mxp1 - first maxilliped, Mxp2 - second maxilliped, PNT - projection neuron tract, P - pereiopod anlagen, PI - pleopod anlagen, PoC - posterior caecum, PS pyloric stomach, Ros - rostrum, SEG - suboesophageal ganglia, TG - thoracic ganglia, VFM - flexor muscles, VNC -ventral nerve cord. Scale bars represent $200 \mu \mathrm{m}$

with the digestive gland, the midgut is adjoined by the hindgut.

The digestive gland (also called midgut gland or hepatopancreas), is a paired organ system flanking and surrounding the foregut and midgut area, that occupies a major part of the cephalothorax (blue in Figs. 3, 4, 5, $6 c, 7 f)$. This organ is composed of an elaborate epithelium surrounding a lumen (Figs. 14a, 15a, b, 17a, c) that forms blindly ending lobes that extend anteriorly and posteriorly (blue in Figs. 4 and 5). On both sides of the organism, we could repeatedly distinguish several types of lobes in several specimens, one dorsal lobe (DL), one ventral lobe (VL), two anterior lobes (AL1, 2), and two posterior lobes (PosL1, 2; Figs. 4 and 5). The organ's lumen has its widest extension in the median part of the gland (Fig. 16a). In adult brachyurans, its epithelium consists of at least four characteristic cell types: embryonic $(\mathrm{E})$, fibrillary $(\mathrm{F})$, resorptive $(\mathrm{R})$, and blister like (B) cells (reviews $[69,70])$. However, following the detailed cytological description laid out by Vogt $[71,50])$ we traced poorly differentiated cells similar to E-cells located at the distal, blindly ending tips of the lobes (Fig. 16e, g). F-cells are also located at the distal end of the lobes and with our staining protocol could be differentiated from E-cells by the darker and more granular cytoplasm (Fig. 16e, f). The R-cells, contain numerous storage vesicles, which in our sections were visible as large, darkly stained inclusions that most likely include lipids (Fig. 16b, f; compare [72]). B-cells include large, unstained central areas (hence their name blister like; Fig. 16b f, g) surrounded by cytoplasm with accumulations of small, dark granula. Many of the cells in the midgut gland did not display such diagnostic features so that we were unable to identify them.

\section{Hindgut in the Zoea IV}

The hindgut is a simple, tubular structure that extends posteriorly throughout the entire pleon and ends in the anus. Like the midgut, it consists of an epithelium with a single layer of columnar cells (Fig. 17e). Another blindly ending caecum, the posterior caecum (poC), arises posteriorly from the hindgut, at the interface of the cephalothorax and the pleon (Fig. 17a-c, e). As for the anterior caeca, the epithelial cells of this structure are columnar and without further specification (Fig. 13c).

\section{Ontogenetic changes}

Based on micro-CT scans of all larval stages, we were able to reconstruct the gross anatomy of the digestive tract to visualize ontogenetic changes (Figs. 3, 4 and 5). Its principal components as described for the Zoea IV are present already at hatching. From the Zoea I to IV, there are gradual changes in its morphology. Also, according to our CT data the first metamorphic moult to the Megalopa is not accompanied by massive structural changes at the macroscopic level. Nevertheless, distinct growth in size and volume occurs from hatching onwards as larval development proceeds into the Megalopa. The midgut and hindgut including the caeca elongate concurrently with the general growth of the larvae (Fig. 4), and the cardiac and pyloric stomach increase in volume. Additionally, the morphological separation between the cardiac and pyloric stomach becomes more distinct towards the end of the larval development (Fig. 4). The volume of the midgut gland also increases massively and both the anteriorly and posteriorly protruding lobes become more and more distinctive and extend in length.

\section{Musculature \\ Musculature of the cephalothorax}

From hatching onwards, a complex system of striated muscles drives the functional appendages from the mandible to the second maxillipeds. Among the most prominent muscles that can be distinguished already in the Zoea I (Fig. 3) are the paired mandibular adductor muscles (MA), that provide forceful movements of the mandibles, which in concert with the gastric mill macerate food items (for the Zoea IV, see Figs. 11a, b, 12c, 13a, 14a). These massive muscles are already visible in whole mount specimens under low power microscopic magnification (data not shown) and are attached dorsally to the integument of the cephalothorax just anteriorly of the dorsal spine (Figs. 3, 7b, 8). They taper ventrally where they attach to the mandible via a tendon. Each mandible adductor muscle consists of several bundles organized in three rows. From the Zoea I to the Zoea IV, a massive 

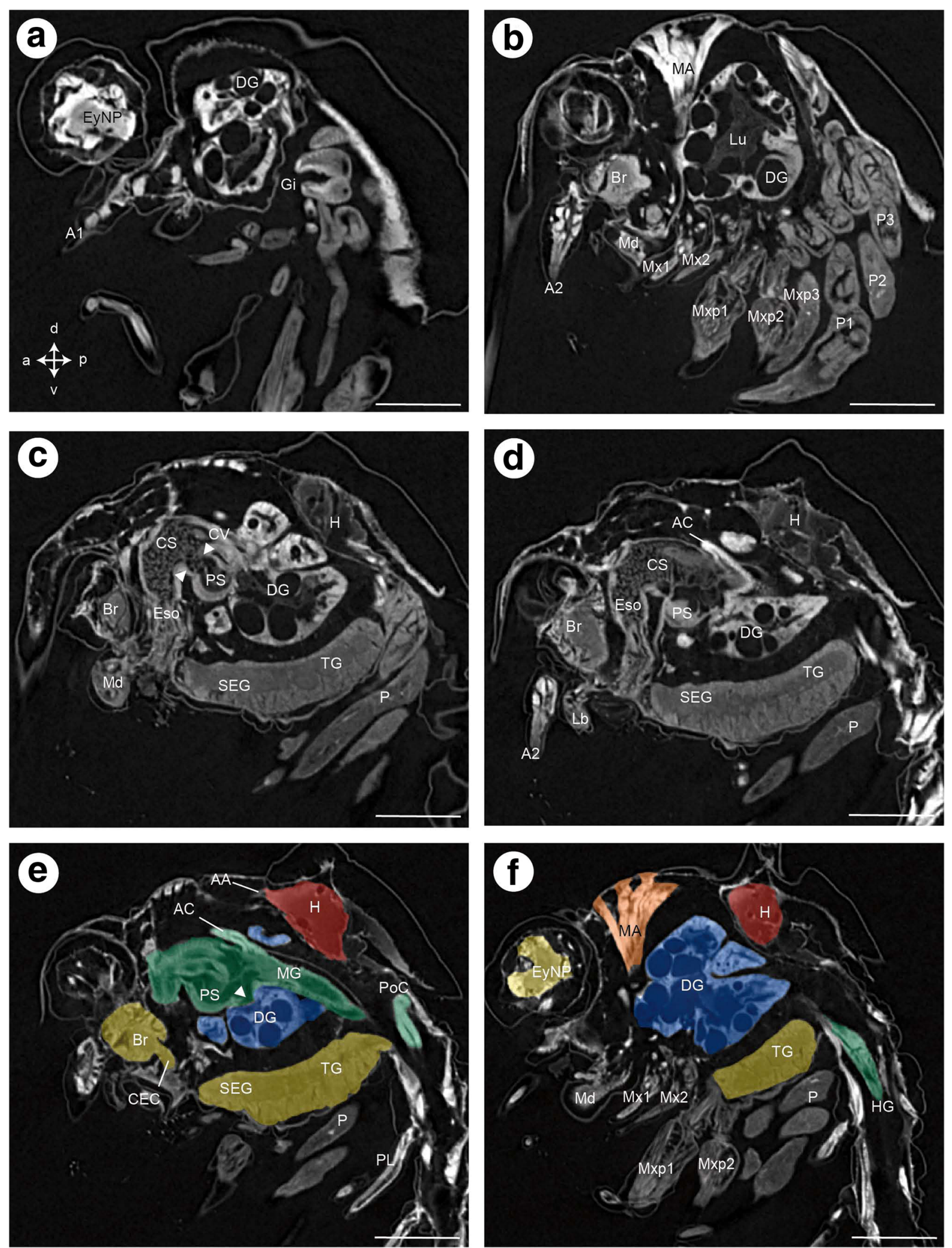

Fig. 7 (See legend on next page.) 
(See figure on previous page.)

Fig. 7 Zoea IV, consecutive lateral sections (a - f) from micro-CT analysis. In e and $\mathbf{f}$, the organs are coloured according to code used in Fig. 5. Crossed arrows in A indicate the orientation ( $\mathrm{a}$ - anterior, $\mathrm{d}$ - dorsal, $\mathrm{p}$ - posterior, $\mathrm{v}$ - ventral). Abbreviations: A1 - first antenna, A2 - second antenna, AC - anterior caecum, AG - antennal gland, Br - median brain, Bst - epithelium of the branchiostegite, CS - cardiac stomach, CV cardio-pyloric valve, DA - descending artery, DCL - deutocerebral chemosensory lobe, DEM - dorsal extensor muscle, DG - digestive gland, Eso - oesophagus, EyNP - eyestalk neuropil, Gi - gill, H - heart, HG - hindgut, Lb - labrum, Lu - lumen of digestive gland, MA - mandibular adductor musculature, Md - mandible, Mxp1 - first maxilliped, Mxp2 - second maxilliped, Mxp3 - third maxilliped, PNT - projection neuron tract, P - pereiopod anlagen, PI - pleopod anlagen, PoC - posterior caecum, PS - pyloric stomach, Ros - rostrum, SEG - suboesophageal ganglia, TG thoracic ganglia, VFM - flexor muscles, VNC - ventral nerve cord. Scale bars represent $200 \mu \mathrm{m}$

growth of these muscles is evident, concurrent with the growth of the entire organism (Fig. 3).

Spanning dorsally across the ventral nerve cord, bundles of medially fused muscles connect the proximal elements of the second maxilla in the Zoea IV (Fig. 15b). This type of musculature we found also associated with the first maxilla and the first and second maxillipeds (data not shown). The maxillipeds of the Zoea IV also contain fully developed intrinsic musculature (Fig. 17a, b). The pereiopod anlagen of the Zoea IV contain undifferentiated tissue but not any striated musculature
(Fig. 17d, g, h). However, at the megalopa stage, the pereiopods have become completely functional as walking legs (Fig. 3) and include fully developed striated musculature (data not shown; compare [24]).

\section{Pleonal musculature}

Starting with the Zoea I, each of the six pleomeres includes dorsal extensor muscles (DEM), which anteriorly are fan-shaped and flattened, and posteriorly copped (Fig. 4, 5, 17c, e), and also ventral flexor muscles (VFM; Fig. 17e). Both types of musculature increase in size and
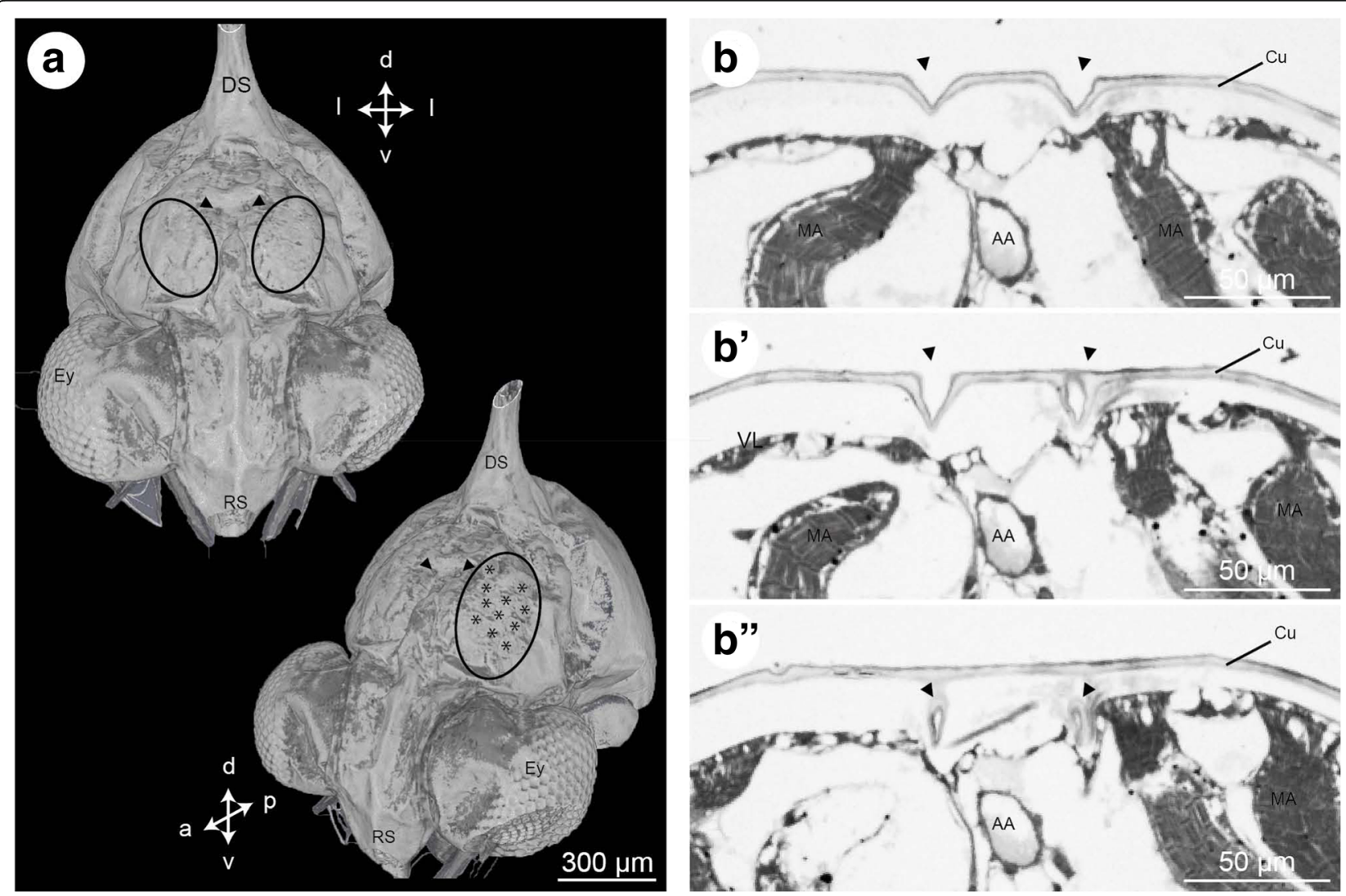

Fig. 8 a - Zoea IV, isosurface of micro-CT-scans showing the external pores of the dorsal organ (black arrowheads) between the attachment sites of the mandibular adductor muscles (circles). Asterisks indicate the attachment of single muscle bundles. Crossed arrows indicate the orientation ( - anterior, $d$ - dorsal, $p$ - posterior, $v$ - ventral). $\mathbf{b}$ - Zoea IV, consecutive frontal semi-thin sections through the pores (arrowheads) of the dorsal organ (anterior is towards the top). Abbreviations: AA - anterior aorta, Cu - cuticle, DS - dorsal spine, Ey - compound eye, MA - mandibular adductor musculature, RS - rostral spine 

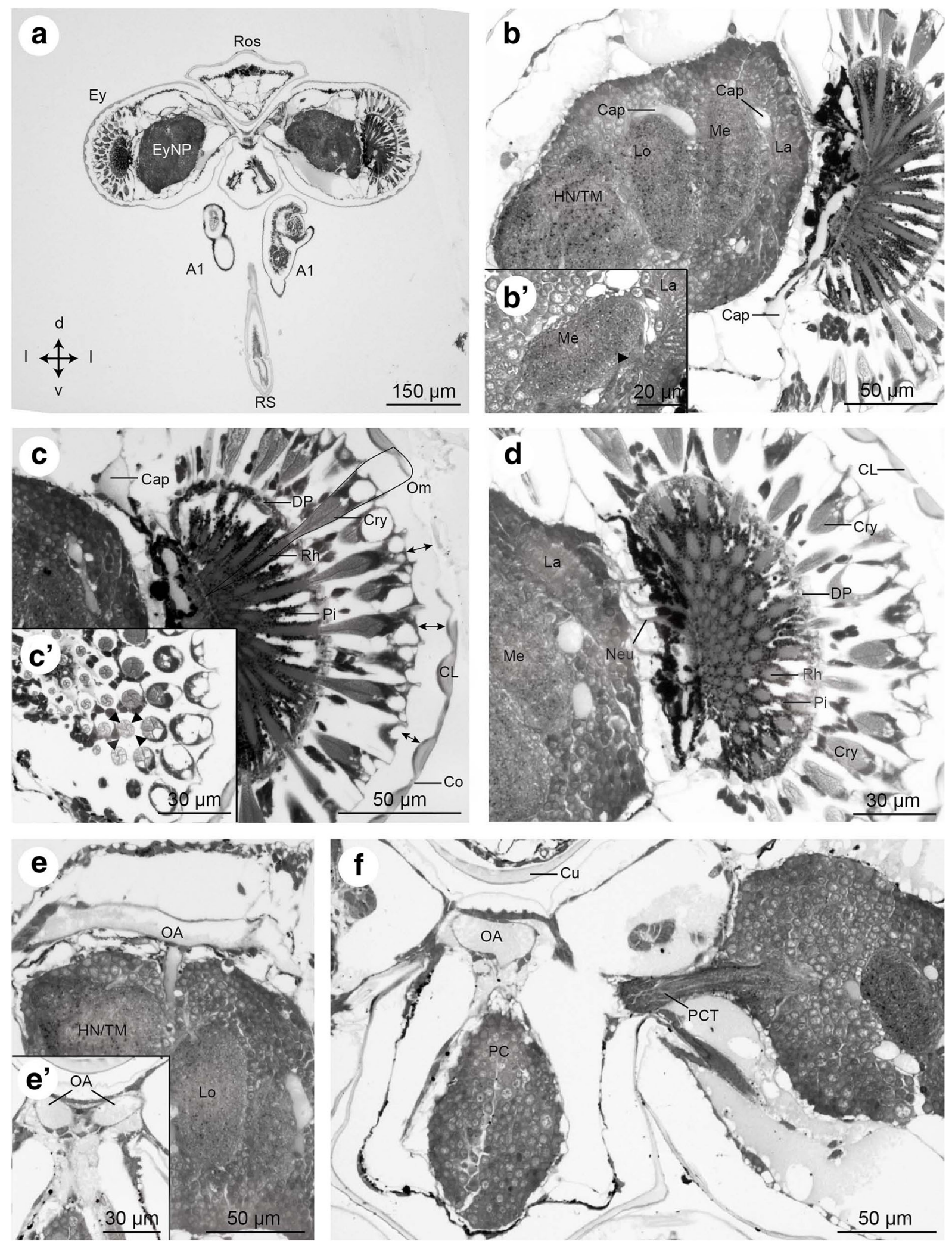

Fig. 9 (See legend on next page.) 


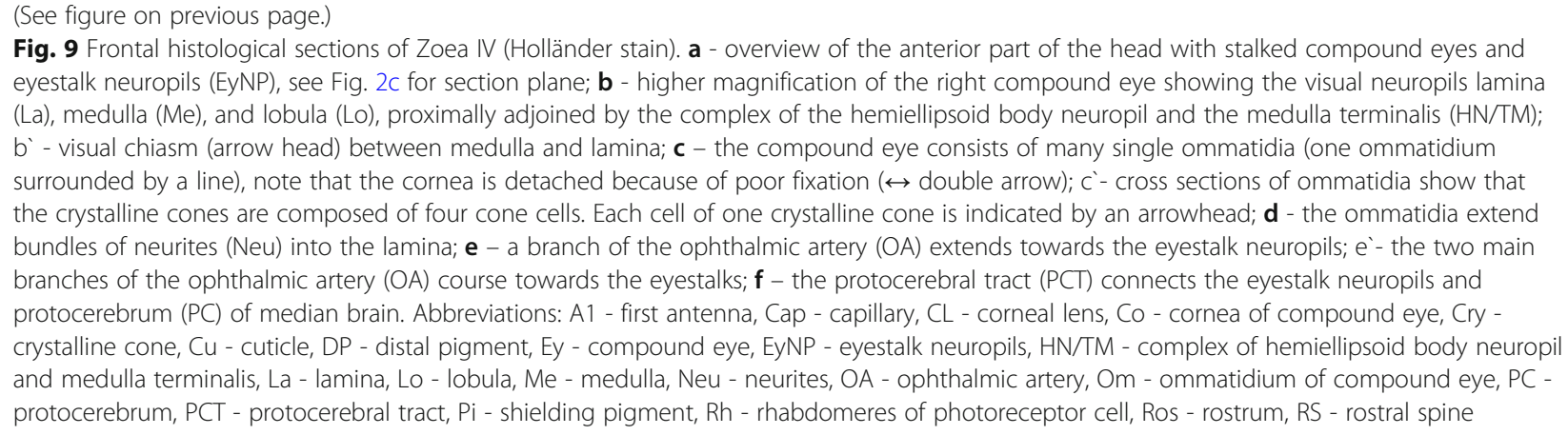

complexity from one larval stage to the next (Fig. 4). The pleopod anlagen in the Zoea I and Zoea II contain undifferentiated tissue inside (data not shown) and cross striated muscles are visible from the Zoea III onwards (Fig. 4). The first and sixth pleomeres are not equipped with any pleopods. In the Zoea IV, the pleopod musculature consists of three distinct muscle strands that extend into the pleopods. These muscles have further increased in size in the Megalopa (Fig. 4).

\section{Heart and circulatory system}

The heart $(\mathrm{H})$ is present at hatching and is positioned dorsally, directly underneath the dorsal spine. Micro CT data show that the volume of the heart gradually increases during larval development (Figs. 3 and 15c-d). In cross-sections of the Zoea IV, the heart displays a triangular shape. A very thin sheet of muscle tissue, the myocardium, forms its wall (Figs. 15b, d, and 16a). The heart is embedded within the haemolymph-filled pericardial cavity (PCav) underneath the integument of the dorsal carapace. Haemolymph from the pericardial cavity enters the heart via ostia in the myocardium $(\mathrm{O}$; Fig. 15d). Similar to the arrangement in adult Brachyura ([73]), in the Zoea IV, we could identify three main arterial vessels that exit the heart: the anterior aorta (AA; also called dorsal medial artery), the posterior aorta (PA; also called the superior pleonal artery), and the descending artery (DA). The anterior aorta projects anteriorly towards the cephalic region to supply the median brain and eyestalk ganglia (Figs. 11a, b, 12a, b, 13a, 14a, and 16a).

At the position where the eyestalks attach to the cephalothorax, the anterior aorta abruptly bends ventrally in a 90 degrees angle to course towards the median brain (Fig. 10a, g, h). Before reaching the median brain, the anterior aorta widens to form an ovoid chamber, the auxiliary heart or cor frontale (CF), a structure that has been described in many adult decapod crustaceans [74]. The ophthalmic artery (OA) leaves the cor frontale anteriorly, towards the eyestalks (Figs. 9f and 10a, b). There, it splits into two branches that invade the left and right eyestalks (Fig. 9e'). The cerebral artery (CA) descends ventrally from the cor frontale to invade the median brain (Figs. 10i-k). In agreement with the description on adult crayfish provided by Chaves da Silva et al. ([75]), the stomatogastric ganglion (STG) is located within the cor frontale (Fig. 10I). In addition, we could identify the cor frontale muscles (CFM) based on the anatomical description provided by these authors (Figs. 10i, j).

A conspicuous tissue composed of small, darkly stained cells is located posteriorly to the cor frontale, but anteriorly to the epithelium of the cardiac stomach. Again, based on the description provided for adult crayfish, ([75], [76]), we tentatively identify this cluster of cells as representing the anterior hematopoietic tissue (HPS; Figs. 10k and 11b).

The posterior aorta leaves the heart posteriorly to supply the pleon with haemolymph (Fig. 17b, c). The descending artery leaves the heart ventrally (data not shown; for details see [24]) to pass through the ventral nerve cord (Fig. 17d, f). It continues ventrally as sternal or subneural artery to supply the ventral nerve cord and the developing cephalothoracic limbs with haemolymph.

\section{lon-transporting and respiratory epithelia, excretory and secretory systems Gills}

In accordance with the study by Hong ([77]) we could not find any gill anlagen in the Zoea I. The first tiny gill buds emerge in the Zoea II and continue to grow in the Zoea III (data not shown). In the Zoea IV, the gill anlagen can be recognized as undifferentiated tissue at the proximal regions of the developing pereiopods (Gi; Figs. $6 \mathrm{~d}, \mathrm{e}, 7 \mathrm{a}$ and $17 \mathrm{~g}$ ). The gill anlagen of the pereiopods one to three become lamellate and functional during the metamorphosis to the Megalopa, the other anlagen become functional after moult to the first juvenile [77].

\section{Branchiostegites}

In adult brachyurans, the branchiostegites, i.e. the lateral carapace folds that form the branchial chamber, function as additional organs involved in the transport of gases and ions [78]. In decapod larvae, it has been suggested 

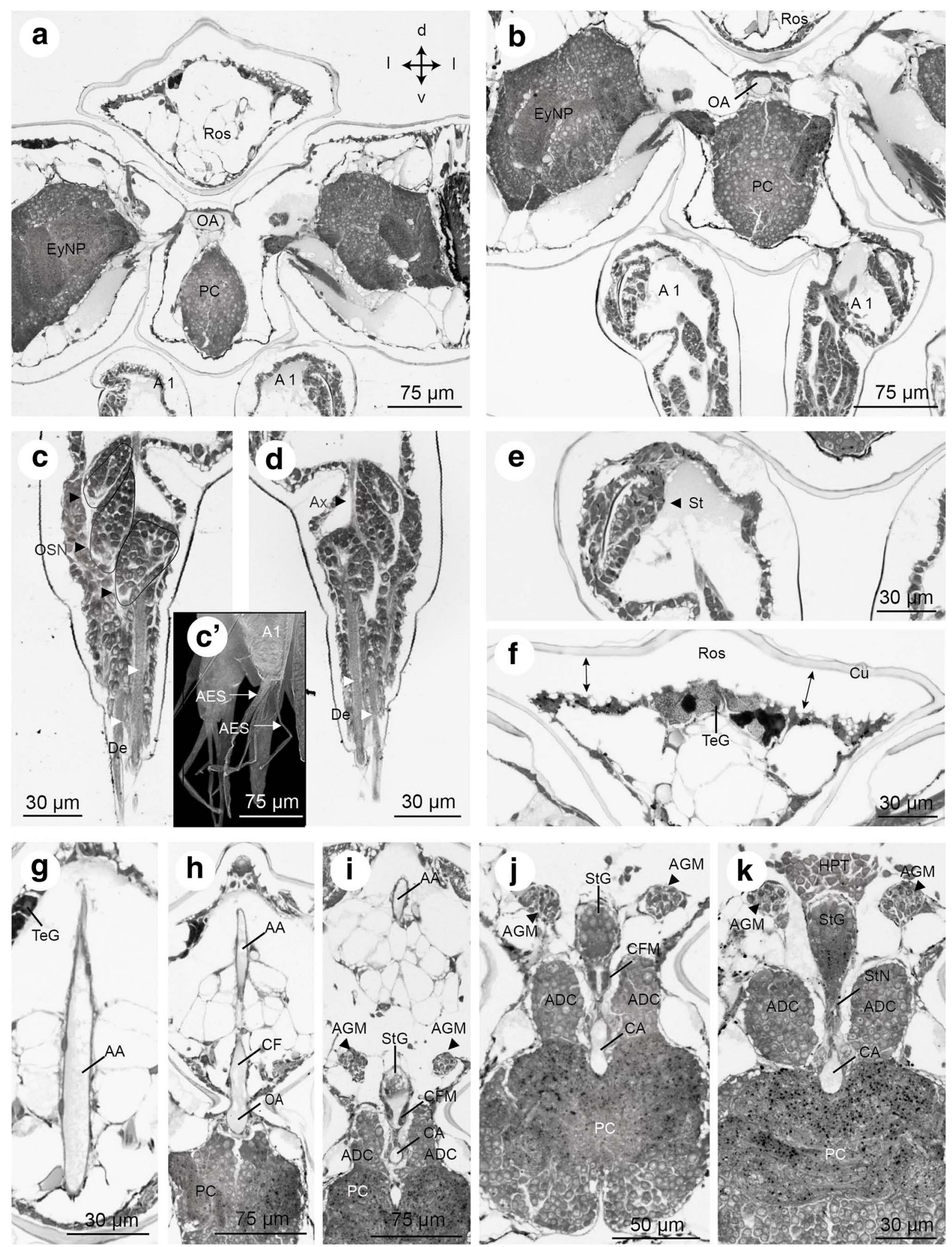

Fig. 10 (See legend on next page.) 


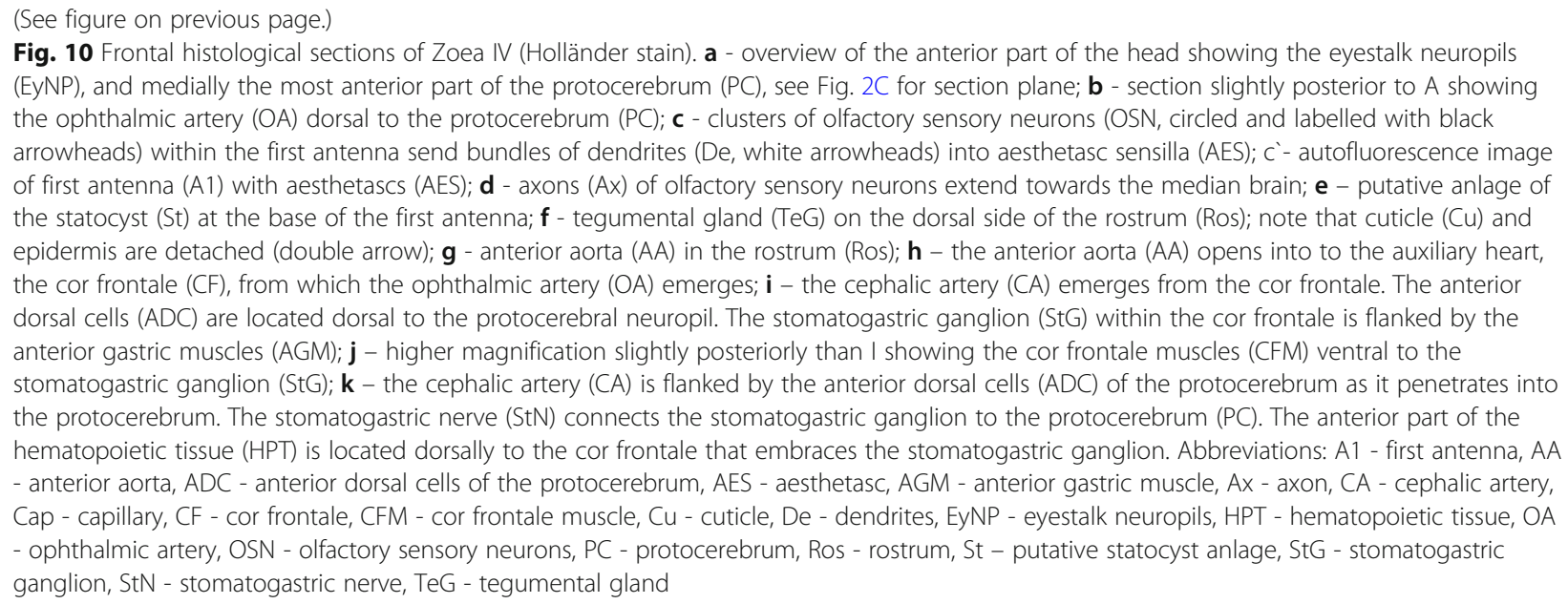

that the epidermis of the branchiostegites acts as an ion-transporting epithelium [43], [44], [79], [45]. In our preparations, the epidermis was artificially detached from the cuticle in the region of the branchiostegites (Bst; Figs. 17a-c, g) and the entire cephalothorax (e.g. Figs. 13a and 14a) possibly due to osmotic effects during fixation. Although we found indications that the epidermis might have a more complex structure in the region of the branchiostegites, compared to the other regions of the cephalothorax, we did not analyse these tissues any further to avoid misinterpretation due to the possible artefacts.

\section{Antennal glands}

In the Zoea IV, antennal glands (AG) are located on both sides of the cephalothorax close to the insertion of the second antenna (Figs. 12a, b and 13a). They are considered to function as larval excretory organs (review [3]; and $[80,81])$. Corresponding to this organ's organization in adult decapods [73], we could identify a coelomosac which receives the haemolymph (Fig. 12c). The coelomosac is connected to a labyrinth from where the urine passes to the bladder (Fig. 13c). The bladder extends dorsally and turns into the nephridial canal. The nephridial canal opens to the outside through a nephropore (Fig. 13c').

\section{Tegumental glands}

In the Zoea IV, many tegumental glands (TeG) of the rosette type [32] are present, usually just beneath the surface of the integument. They consist of cells with a lightly stained cytoplasm (Fig. 11e), which are radially arranged around a small pore which most likely is a duct connecting the gland to the surface. Some of the cells displayed darkly stained inclusions. Here, we documented tegumental glands at the base of the rostrum (Fig. 10 F), embedded within the labrum (Fig. 11b, e), and proximally within the mandibles (Fig. 15a).

\section{Y-organ}

Based on the anatomical description provided in Höcker [82], we were able to localize the endocrine Y-organs in the Zoea IV. This organ is an inconspicuous accumulation of cells located laterally underneath the carapace and embedded within the epidermis of the branchiostegites (Fig. 16d). In an anterior-posterior direction, this organ is located roughly between the anlagen of the third maxilliped and the first pereiopod.

\section{Sensory systems \\ Compound eyes}

In the Zoea IV, the compound eyes are located at the distal tip of the eyestalks (Fig. 9a) and are composed of numerous single units, the ommatidia. Each ommatidium consists of light guiding structures, the corneal lens $(\mathrm{Cl}$, Fig. 9c, d) and the crystalline cone (Cry), formed by four cone cells (Fig. 9c'). Unfortunately, in our semi-thin sections, the cornea was detached from the underlying tissue due to poor fixation (indicated by arrows in Fig. 9c). The retinular cells that contain the photopigments jointly form the rhabdom (Rh, Fig. 9c). The rhabdomeres of the neighbouring ommatidia are optically isolated from each other by screening pigment cells $(\mathrm{Pi})$. Between the proximal and the distal region of the ommatidia there is a separating layer of distal pigment (DP). The axons of retinular cells target the visual neuropils in the eyestalks (Fig. 9d). Compound eyes are already present at hatching and their developmental elaboration in C. maenas was described [25].

\section{Aesthetascs}

In the Zoea IV, the first antenna is equipped with chemosensory sensilla, the aesthetascs (AES; Fig. 10c'). In longitudinal sections of the first antenna, we localized aesthetascs that project from the distal segment of the antennae (Fig. 10c, d), most likely corresponding to aesthetascs number one, two and three following the 

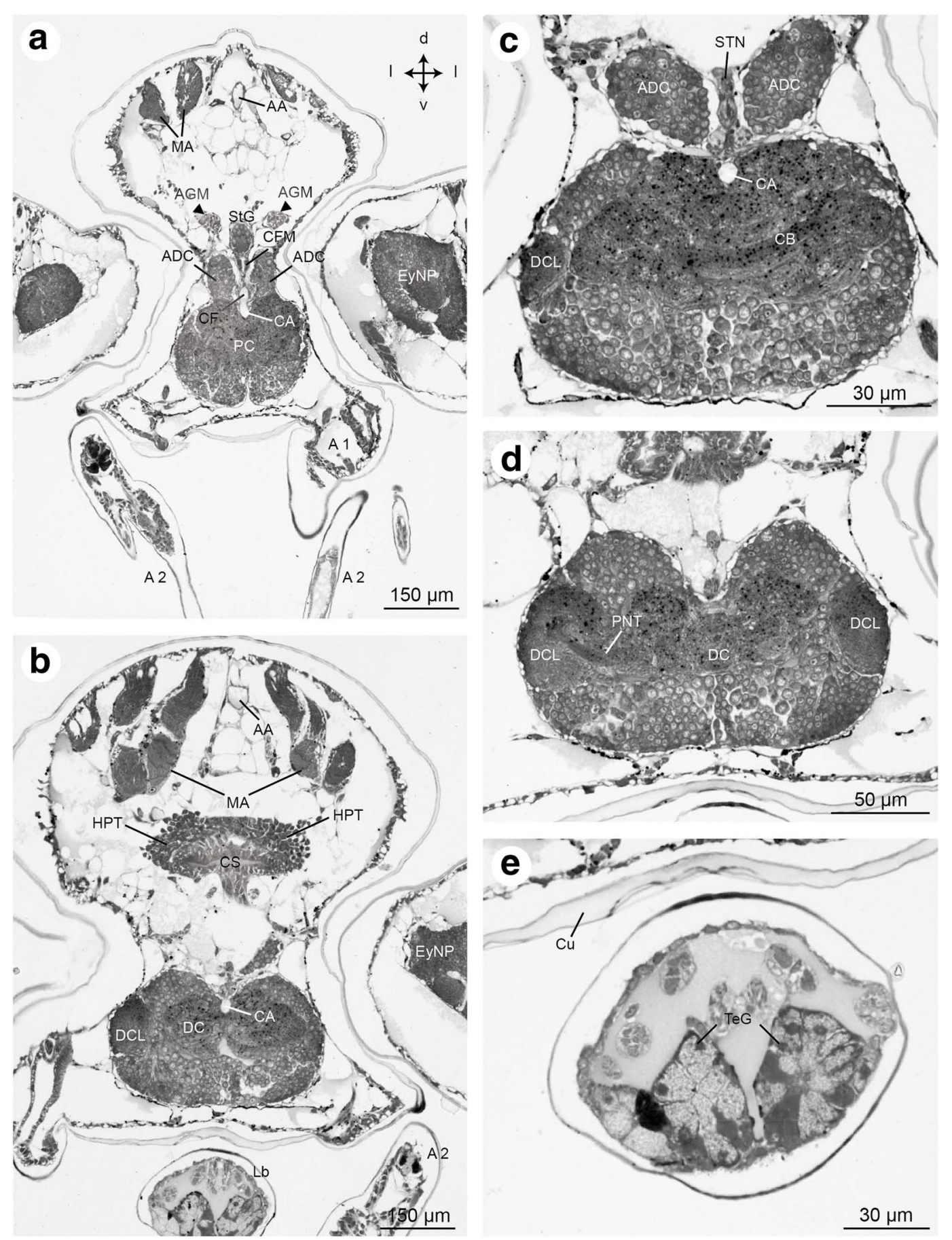

Fig. 11 Frontal histological sections of Zoea IV (Holländer stain). a - overview showing the median brain and anterior part of the cephalothorax, see Fig. 2C for section plane; $\mathbf{b}$ - overview slightly posterior to A showing the prominent mandibular adductor musculature (MA) dorsally, on the ventral side the labrum (Lb) and second antenna (A2). Hematopoietic tissue is associated dorsally and laterally with the wall of the cardiac stomach (CS); $\mathbf{c}$ - the unpaired central body (CB) is located in the centre of the protocerebrum that is dorsally surmounted by the anterior dorsal cells (ADC). The stomatogastric nerve (STN) is also visible. $\mathbf{d}$ - the deutocerebrum is characterized by spherical deutocerebral chemosensory lobes (DCL) on both sides. The projection neuron tract (PNT) emerges from the left DCL. e - rosette-shaped tegumental gland (TeG) in the labrum. Abbreviations: A1 - first antenna, A2 - second antenna, AA - anterior aorta, ADC - anterior dorsal cells of the protocerebrum, AGM - anterior gastric muscle, CA - cephalic artery, CB - central body, CF - cor frontale, CFM - cor frontale muscle, CS - cardiac stomach, Cu - cuticle, DC deutocerebrum, DCL - deutocerebral chemosensory lobe, EyNP - eyestalk neuropil, HPT - hematopoietic tissue, Lb - labrum, MA - mandibular adductor musculature, PC - protocerebrum, PNT - projection neuron tract, Ros - rostrum, StG - stomatogastric ganglion, StN - stomatogastric nerve, TeG - tegumental gland 


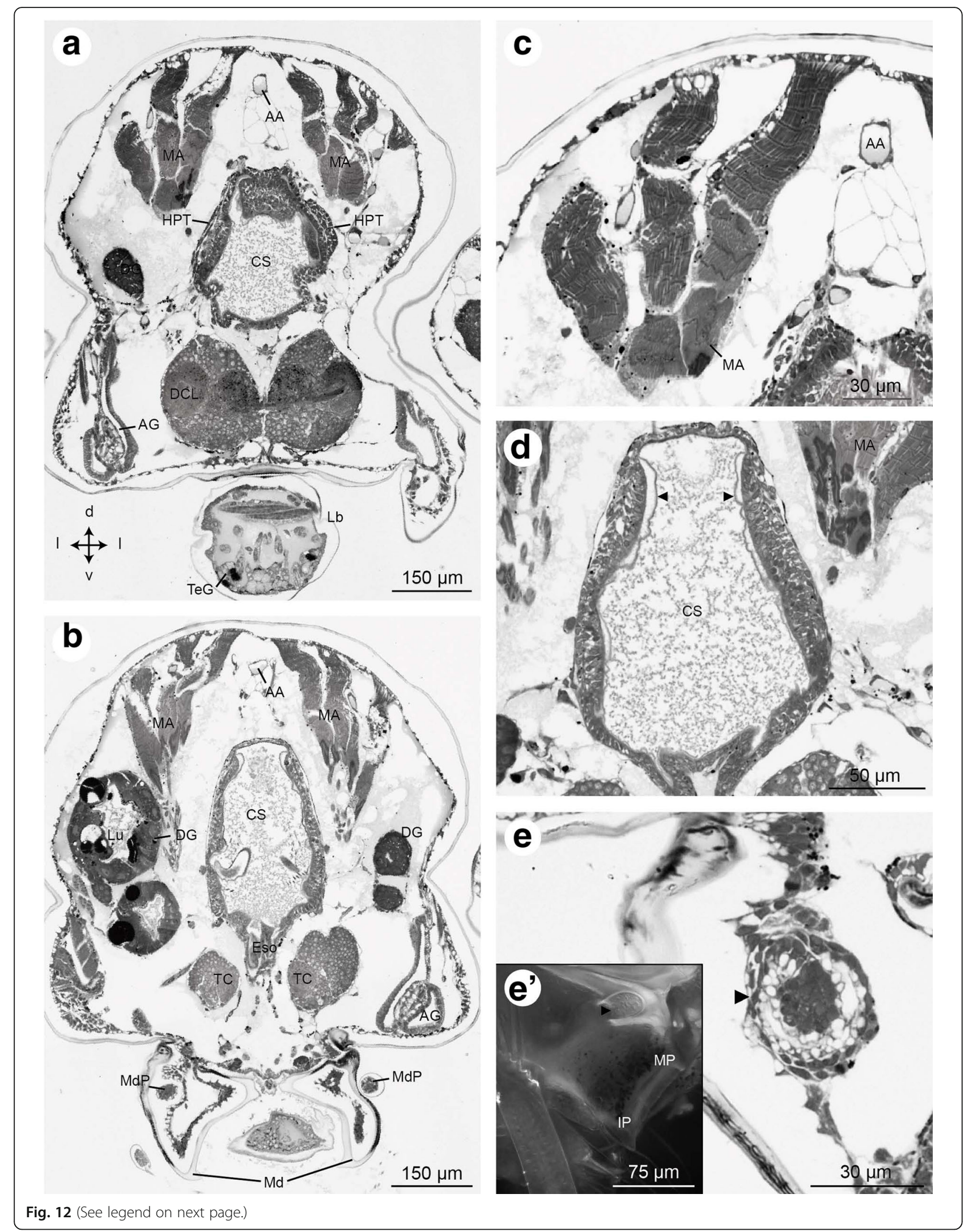




\section{(See figure on previous page.)}

Fig. 12 Frontal histological sections of Zoea IV (Holländer stain). a - section showing the median brain at the level of the deutocerebral chemosensory lobes and the cardiac stomach, see Fig. $2 \mathrm{C}$ for section plane; $\mathbf{b}$ - section slightly more posterior to A showing the tritocerebrum (TC) flanking the oesophagus (Eso), and the anterior lobes of the digestive gland with its lumen (Lu) and large lipid inclusions (black dots). The right antennal gland (AG) is also visible. c - mandibular adductor musculature (MA) displays the characteristic cross striation; $\mathbf{d}$ - the anterior part of the cardiac stomach (CS) inside is lined with cuticle (arrowheads); e - inner portion of the anlage of the mandibular palp located inside of the mandible; e'- autofluorescence of the mandible with the outer portion of the mandibular palp anlage (arrowhead). Abbreviations: AA - anterior aorta, AG - antennal gland, CS - cardiac stomach, DCL - deutocerebral chemosensory lobe, DG - digestive gland, Eso - oesophagus, HPT - hematopoietic tissue, Lb - labrum, Lu - lumen of digestive gland, MA - mandibular adductor musculature, Md - mandible, MdP - mandibular palp, TC - tritocerebrum, TeG - tegumental gland

terminology laid out in ([83]). Deeper within the antennae, clusters of cell somata belonging to olfactory sensory neurons (OSN) could be observed (circles in Fig. 10c). Bundles of dendrites (DE) project from the somata into the aesthetascs sensilla. In one section, a bundle of axons (Ax) was traced that projected from the OSN cluster proximally towards the median brain (Fig. 10d).

\section{Putative anlage of the statocyst}

In the Zoea IV, an accumulation of tissue is present embedded within the proximal part of the first antenna (Fig. 10b). It appears as an ellipsoid, multicellular complex surrounding a narrow cavity (Fig. 12e). This narrow, slit-like cavity is flanked, on both sides, by a cell layer, that is two to four cells thick. We tentatively identified this structure as the anlage of the statocyst although we did not find any statolith at this stage (see discussion).

\section{Dorsal organs}

In the Zoea IV, surface views generated from micro-CT scans show the external pores of the dorsal organs in a position corresponding to that described by Meyer et al. ([19]). The pores are located dorsally in front of the dorsal spine on both sides of the midline (Fig. 8a - black arrowheads) and close to the attachment sites of the mandibular adductor muscles. Semi-thin sections show that these pores are formed by conical indentions of the dorsal cuticle close to the anterior aorta (Fig. 8b, b'). These indentions extend deeper below the body surface but with the methods used here we could not trace any cellular material associated with the cuticular indentions (Fig. 8b").

\section{Central nervous system \\ The brain of the Zoea IV}

The brain or syncerebrum is composed of the eyestalk neuropils and the median brain (nomenclature according to [24] with modifications according to [84-86]). As is typical for the arthropod nervous system in general, the neuronal somata surround a core of synaptic neuropil. The eyestalk comprises the visual neuropils lamina (La), medulla (Me) and lobula (Lo; Figs. 5 and 9b), and the associated neuronal somata. The lamina is a thin neuropil layer located proximally to the retina $(\mathrm{Re})$ of the compound eye from which it receives bundles of the photoreceptor axons (Fig. 9d). The neurites that link the lamina and medulla form a characteristic chiasm (Fig. 9b - black arrow head). The hemiellipsoid body/medulla terminalis neuropil complex (HN/TM) is located most proximally within the eyestalks, and according to embryological data, is part of the protocerebrum [87]. This latter neuropil complex receives a direct input from the deutocerebral chemosensory lobes (DCL) via the projection neuron tract (see below). The eyestalk neuropils are connected to the median brain via the protocerebal tract (PCT; Figs. 5 and 9f) which includes the projection neuron tract (PNT; see below). The protocerebrum (PC) is the most anterior part of the median brain and consists of a large cluster of cell somata that surrounds the protocerebral neuropils anteriorly and dorsally (Figs. 9f and $10 \mathrm{a}, \mathrm{b})$. The central body (CB) is an unpaired, transversally extending neuropil embedded within the protocerebrum (Fig. 11c). The anterior dorsal cells cluster (ADC), a conspicuous cluster of neuronal somata, is located on top of the protocerebrum (Figs. 10j, $\mathrm{k}$ and 11c). The unpaired stomatogastric ganglion (STG) is located within the cor frontale (see above) and is flanked by the anterior dorsal cell cluster. This ganglion is located directly anteriorly to the cardiac stomach and provides an innervation for the entire gastric system (Figs. 10j, k and 11a). The deutocerebrum (DC), the second neuromere of the syncerebrum, receives input from the first pair of antennae. It is situated posteriorly to the protocerebrum and is dominated by the paired deutocerebral chemosensory lobes (DCL; previously called "olfactory lobes"; Figs. 11c, d and 12d). These are the primary chemosensory processing areas, which receive input from the olfactory sensory neurons on the first antennae and are located laterally within the deutocerebrum. The deutocerebral chemosensory lobes are dense, spherical neuropils that are ventrally accompanied by a large cluster of cell somata of olfactory interneurons from which neurites project into the neuropil. A characteristic bundle of axons leaves the DCL, the projection neuron tract (PNT; Fig. 11d). It projects medially, where its fibres form a characteristic chiasm and continue towards the eyestalks to terminate in the HN/TM complex (data not shown). The tritocerebrum (TC), the 3rd neuromere of the syncerebrum, caudally adjoins the deutocerebrum. Its bilateral halves are medially connected by the small 


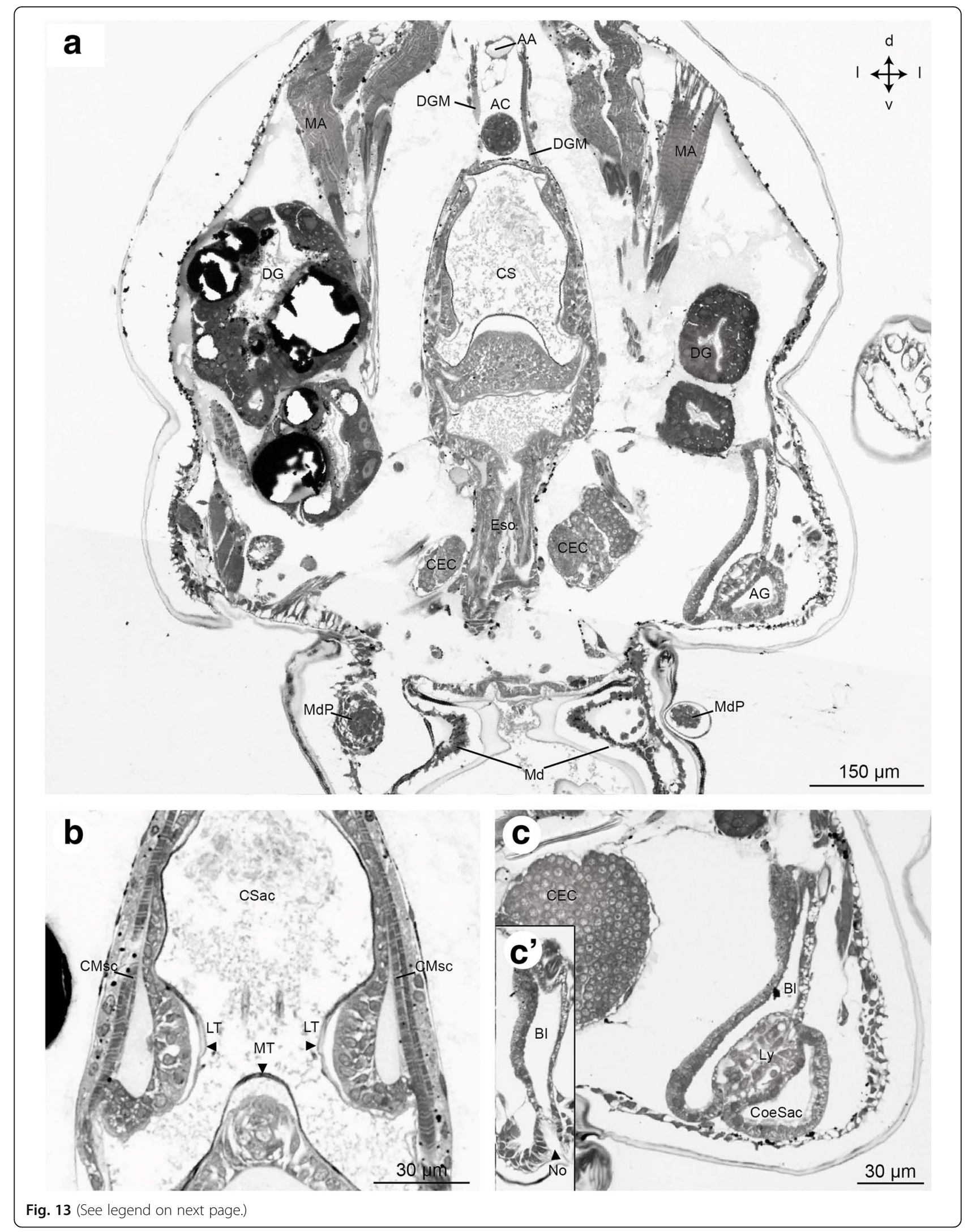


(See figure on previous page.)

Fig. 13 Frontal histological sections of Zoea IV (Holländer stain). a - section through the median part of the cardiac stomach (CS), see Fig. 2c for section plane; $\mathbf{b}$ - higher magnification of the cardiac stomach with the gastric mill that comprises two lateral teeth (LT) and one median tooth (MT), note the thickened cuticle of the teeth as indicated by black arrowheads; $\mathbf{c}$ - higher magnification of the antennal gland; $\mathbf{C}^{\prime}$ - the bladder (BL) of the antennal gland opens to the outside through a nephropore (No). Abbreviations: AA - anterior aorta, AC - anterior caecum, AG antennal gland, BI - bladder, CEC - circumoesophageal connective, CMsc - contractor muscles of the cardiac stomach, CoeSac - coelomosac, CS - cardiac stomach, CSac - cardiac sac, DG - digestive gland, DGM - dorsal gastric muscles, Eso - oesophagus, LT - lateral tooth, Ly - labyrinth, MA - mandibular adductor musculature, Md - mandible, MdP - mandibular palp, MT - median tooth, No - nephropore, TC - tritocerebrum

tritocerebral commissure (TC), and in the frontal section plains, the tritocerebral neuropil (TN) is visible close to this commissure (Fig. 12a). The paired circumoesophageal connectives (CEC; Figs. 5 and 13a) flank the oesophagus on both sides, and the commissural ganglia (CG) are laterally associated with the connectives at the level of the oesophagus.

\section{Ventral nerve cord}

The circumoesophageal connectives link the median brain to the ventral nerve cord (VNC) which conforms to the ladder-like ground plan with paired ganglia, which longitudinally are joined by connectives and transversely by commissures. The neuromeres of the ventral nerve cord display the typical architecture with a central core of synaptic neuropil surrounded by a cortex of cell somata (Figs. 17a, b, d). From anterior to posterior, the mandibular neuromere can be distinguished followed by the neuromeres associated with maxilla 1 and maxilla 2 (compare Fig. 1b). Posteriorly, three neuromeres, associated with the maxillipeds, follow, in addition to five neuromeres associated with the developing pereiopods (walking limbs). The neuromeres form the first mandible down to the third maxilliped collectively are referred to as the suboesophageal ganglia in adults (compare [84]). All postoesophageal neuromeres down to the eight thoracic neuromere are fused to form a synganglion (yellow in Figs. 4 and 5) the segmental composition of which is, nevertheless, obvious from the ganglionic neuropil cores and the nerves extending into the periphery. The pleonal ganglia are posteriorly connected to this synganglion as additional part of the ventral nerve cord (Figs. 4 and 17e). They are smaller than the thoracic ones and have long conspicuous connectives.

\section{Ontogenetic changes}

The general layout of the nervous system in the earlier zoea stages closely resembles that described here in detail for the Zoea IV (Figs. 4 and 5). The basic structure of the central nervous system is already laid out in the first larval stage in which the suboesophageal and thoracic neuromeres are already condensed to form a synganglion. Yet, there is a gradual increase in size from stage to stage. The first metamorphosis to the Megalopa is not accompanied by any dramatic structural changes at the macroscopic level according to the micro CT scans, but again an increase in size of the individual components takes place (Fig. 4 and 5; and compare [24]). One visible difference is that the chain of pleon ganglia appears shorter and more condensed in the Megalopa than in the Zoea IV (Fig. 4).

\section{Discussion}

\section{Digestive system}

In adult brachyuran crustaceans, four regions of the digestive system can be distinguished: oesophagus, foregut, midgut, and hindgut (for references see Table 2). The oesophagus, foregut and the hindgut derive from the ectoderm and thus are lined by a thin cuticle. In adult crabs, the foregut is located dorsally in the cephalothorax, surrounded by the digestive gland. The midgut and hindgut possess blind ending tubules, the caeca. The hindgut ends with the anus.

\section{Mandibles and Foregut}

In Carcinus maenas, many aspects of the adult organization are already present at hatching. Zoea larvae masticate food items with their strong mandibles, and then take up the food particles by peristaltic movements mediated by the lateral dilatator muscles attached to the oesophagus [3]. The complex gastric mill of the cardiac stomach continues to grind the food particles. In the Zoea IV, the presence of the well-developed stomatogastric ganglion that provides an innervation of the foregut suggests that the stomatogastric mill is able of complex movements. In other brachyuran larvae, it was shown that the teeth and denticles of the gastric mill continue to differentiate into the megalopa and juvenile stages so that the gastric mill gradually takes over the role of masticating food items. In the spanner crab Ranina ranina, for example, the mandible's function switches from cutting and masticating in zoeal stages to cutting and crushing in the following stages and the mandibular incisor and molar process of the Megalopa degenerate [88]. A similar ontogenetic change was shown for larvae of the stone crab Menippe mercenaria [23] and in the gastric mill of the clawed lobster Homarus americanus in which these modifications coincide with the drastic change of habitat and diet that these larvae face after metamorphosis [17].

The ingested food passes from the cardiac stomach across the cardio-pyloric valve to enter the pyloric 

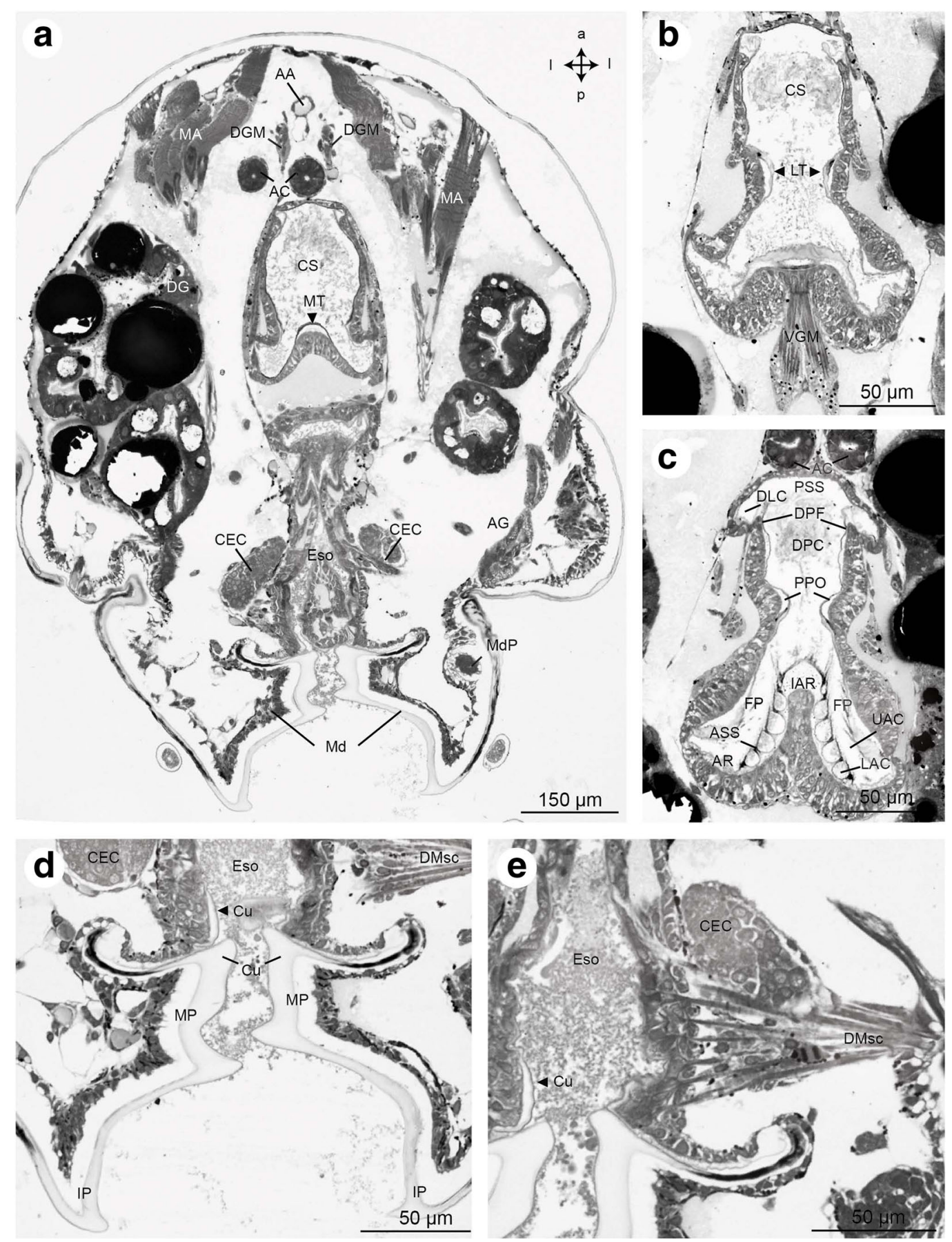

Fig. 14 Frontal histological sections of Zoea IV (Holländer stain). a - section of the cephalothorax with the cardiac stomach (CS) in the centre. Dorsally, the paired anterior caeca (AC) are located. Ventrally the oesophagus (Eso) opens to the mouth field, laterally flanked by the mandibles (Md); compare Fig. 2c for section plane; b - posterior part of the cardiac stomach with sclerotized lateral teeth (LT). Ventrally, the ventral gastric muscles are attached (VGM). $\mathbf{c}$ - details of the pyloric stomach with gastric mill. $\mathbf{d}$ - higher magnification of the sclerotized mandible (Md), note the massive cuticle (Cu) of the molar process (MP); e - detail of the dilatator muscles (DMsc) attached to the oesophagus (Eso). Abbreviations: AA - anterior aorta, AC - anterior caecum, AG - antennal gland, AR - ampullary ridge, ASS - ampullary setal screen of the gland filter, CEC circumoesophageal connective, CMsc - dilatator muscles of the cardiac stomach, CS - cardiac stomach, Cu - cuticle, DG - digestive gland, DGM - dorsal gastric muscles, DLC - dorsolateral pyloric channel, DMsc - dilatator muscles of the oesophagus, DPC - dorsal region of the pyloric chamber, DPF - dorsal pyloric fold, Eso - oesophagus, FP - filter press, IAR - interampullary ridge, IP - incisor process, LAC - lower ampullary chamber, MA - mandibular adductor musculature, Md - mandible, MdP - mandibular palp, MP - molar process, MT - median tooth, PPO - prepyloric ossicle, PSS - pyloric setal screen, UAC - upper ampullary chamber, VGM - ventral gastric muscle 

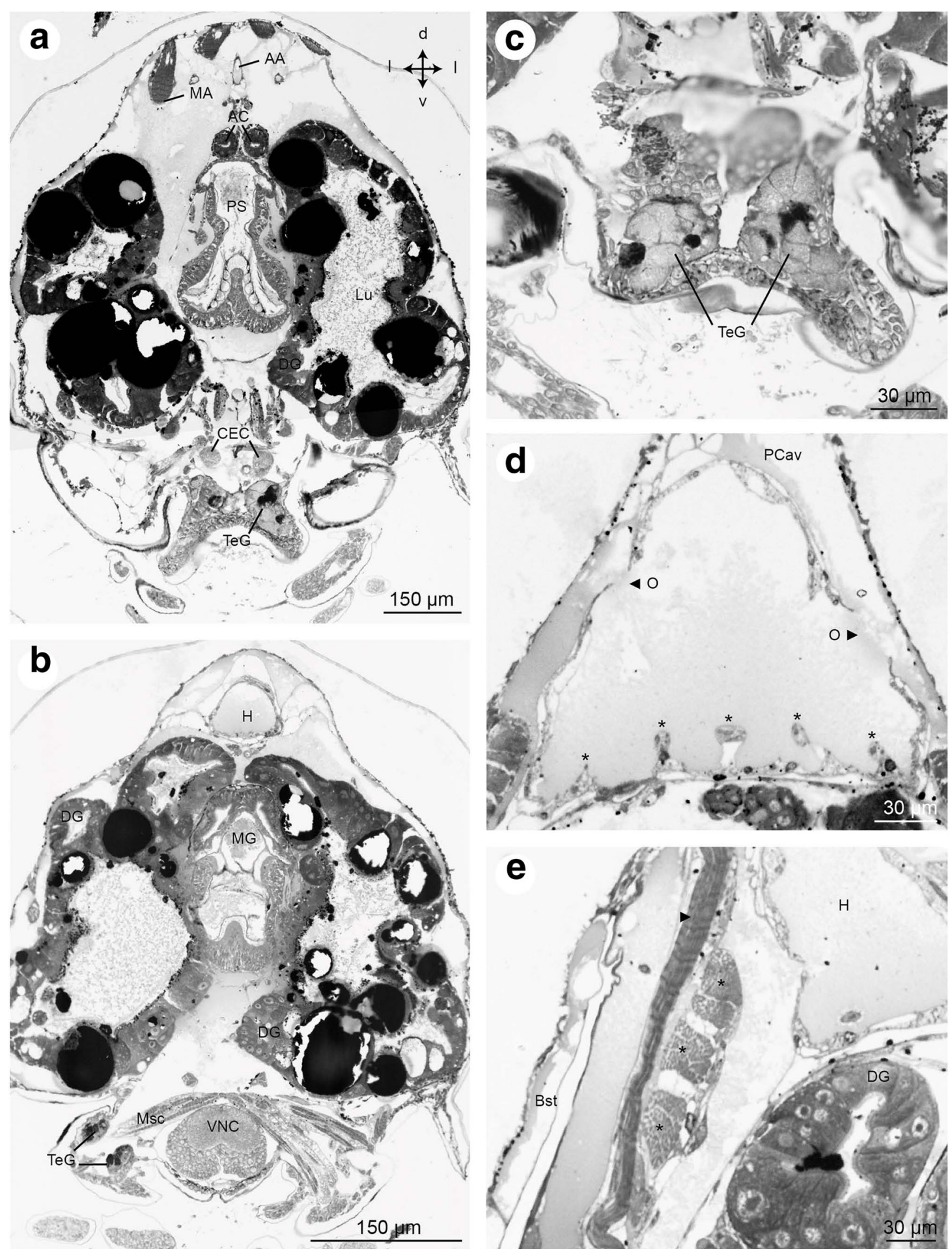

Fig. 15 Frontal histological sections of Zoea IV (Holländer stain). a - section showing the median portion of the pyloric stomach (PS) laterally flanked by the lobes of the midgut gland, see Fig. 2c for section plane; $\mathbf{b}$ - section of the anterior part of the midgut (MG) with the dorsal heart $(\mathrm{H})$ and the ventral nerve cord (VNC) at the level of the suboesophageal ganglia. Dorsally, the VNC is crossed by muscles (Msc) associated with the maxillae; c - higher magnification of rosette-shaped tegumental glands of the mandible; $\mathbf{d}$ - the heart is surrounded by the pericardial cavity (PCav) into which the ostia (O) open. Asterisks identify putative trabeculae; $\mathrm{E}$ - cross section of musculature (asterisks and arrow) laterally to the heart $(\mathrm{H})$ underneath the branchiostegites (Bst). Abbreviations: AA - anterior aorta, AC - anterior caecum, CEC - circumoesophageal connective, DG - digestive gland, $\mathrm{H}$ - heart, Lu - lumen of digestive gland, MA - mandibular adductor musculature, MG - midgut, Msc - musculature of the maxillae, PS - pyloric stomach, TeG - tegumental gland, VNC - ventral nerve cord 

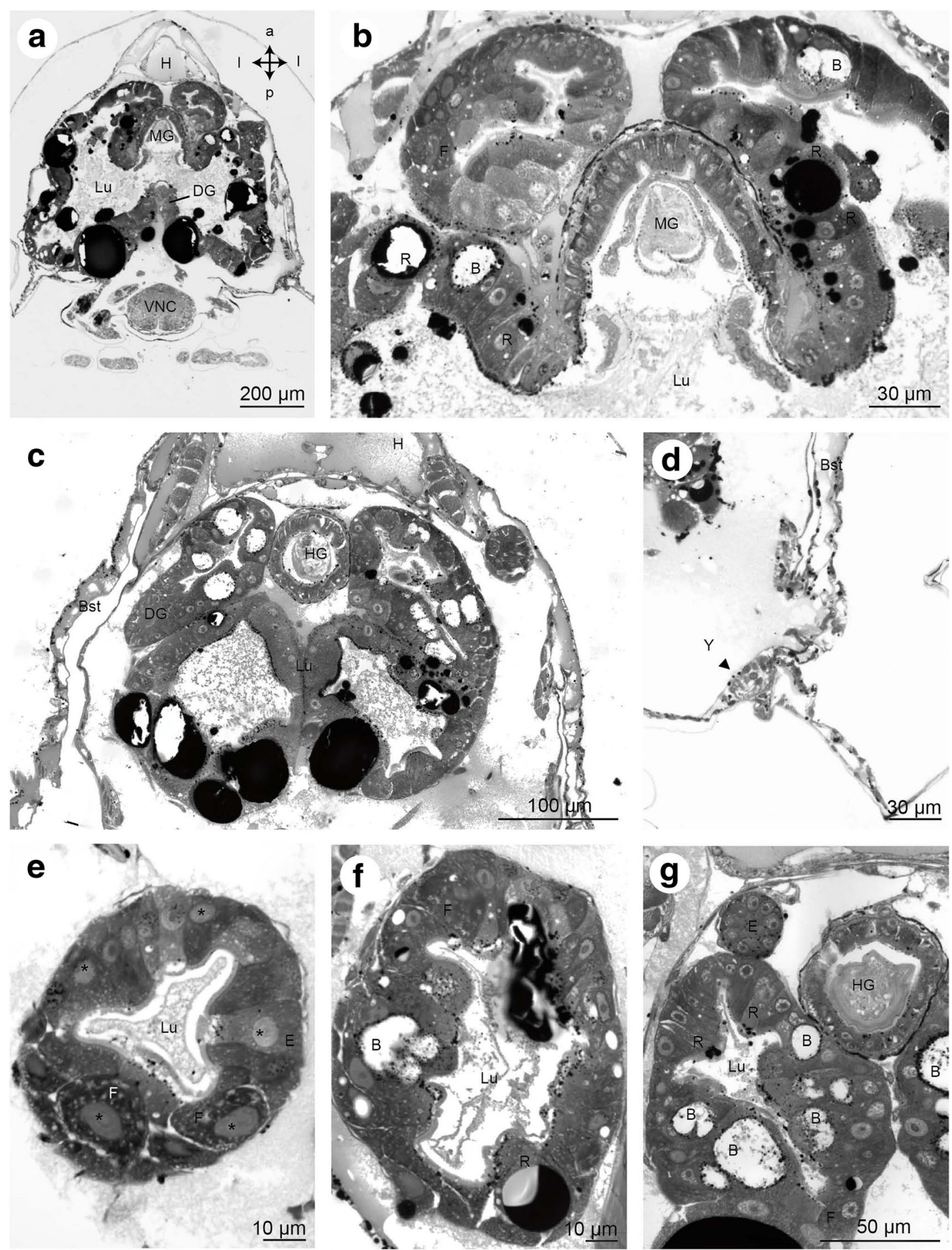

Fig. 16 Frontal histological sections of Zoea IV (Holländer stain). a - cross-section showing the lobes of the digestive gland (DG) opening into the midgut (MG), see Fig. 2c for section plane; $\mathbf{b}$ - close-up of the interface of the digestive gland to the midgut (MG). Cell-types of the digestive gland identified include embryonic cells (E), blister like cells (B) and resorptive cells (R). c - section across the posterior lobes of the midgut gland and the anterior part of the hindgut $(\mathrm{HG})$; $\mathbf{d}$ - the $Y$-organ $(\mathrm{Y})$ is located underneath the lateral carapace close to the interface with the branchiostegites (Bst); e - distal part of a digestive gland lobe showing lumen (Lu) surrounded by epithelium composed of E- and F-cells. $\mathbf{f}$ - section through a lobe of the digestive gland showing epithelium with R-and B-cells surrounding the lumen (Lu). $\mathbf{g}$ - section of the digestive gland more posteriorly than A, the B-, F-, R-, and E-cells are identified. Abbreviations: B - blister like cell, Bst - epithelium of branchiostegite, DG - digestive gland, E - embryonic cell, F - fibrillary cell, H - heart, HG - hindgut, Lu - lumen of digestive gland, MG - midgut, R - resorptive cell, VNC - ventral nerve cord, Y - Y-organ 

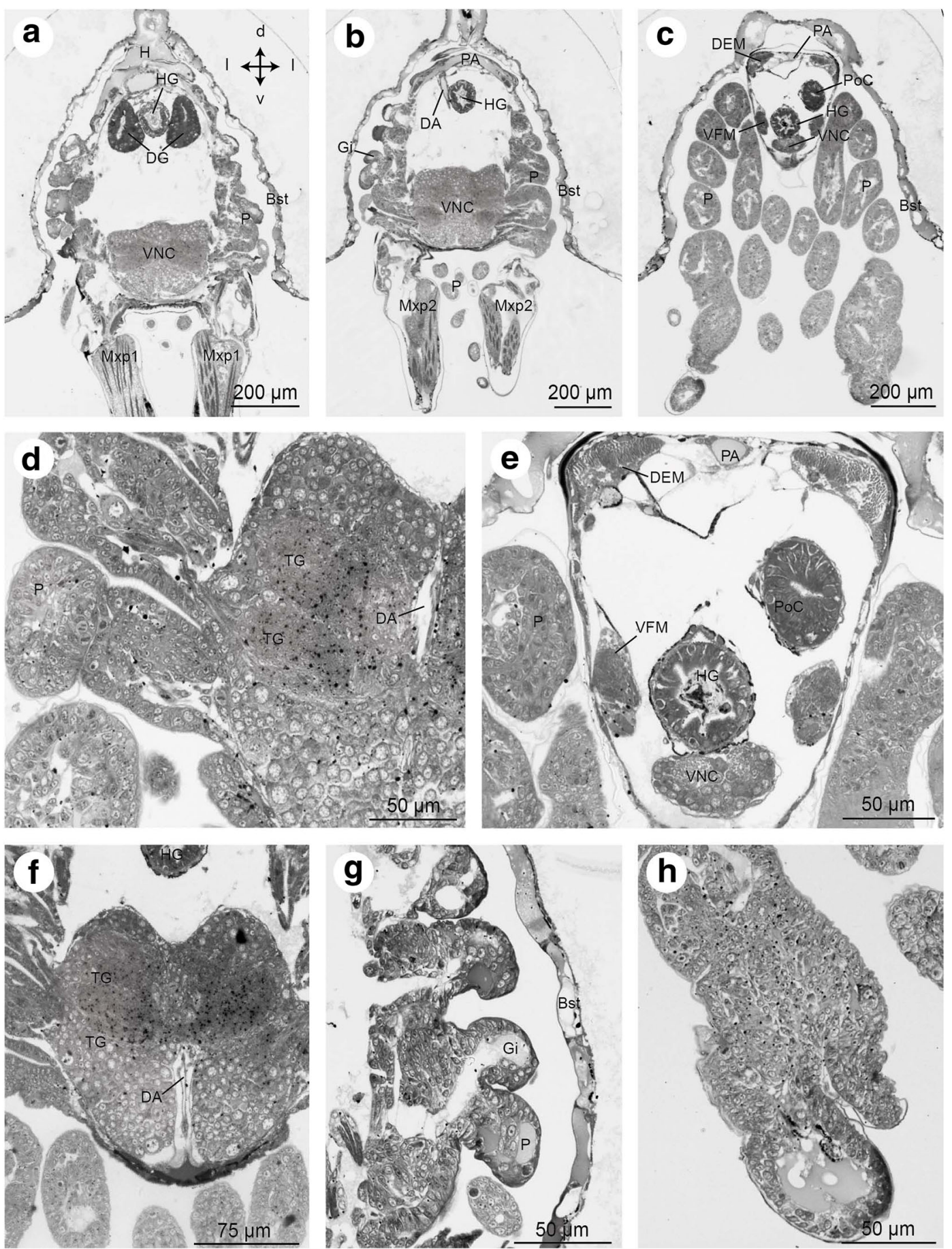

Fig. 17 Frontal histological sections of Zoea IV (Holländer stain). a - section through the distal part of the digestive gland (DG) with the two posterior lobes flanking the hindgut $(\mathrm{HG})$, see Fig. $2 \mathrm{c}$ for section plane. $\mathbf{b}$ - section showing the posterior artery (PA) as well as the descending artery (DA). c - section through the first pleon segment with the hindgut (HG) and its blindly ending posterior caecum (PoC) as well as pereiopod anlagen (P). $\mathbf{d}$ - higher magnification of the ventral nerve cord $(\mathrm{VNC})$, penetrated by the descending artery (DA). $\mathbf{e}$ - higher magnification of the first pleon segment shown in B, the flexor muscles (VFM) and extensor muscles (DEM) of the pleon are identified. $\mathbf{f}$ - higher magnification of the ventral nerve cord (VNC) as it is penetrated by the descending artery (DA). $\mathbf{g}$ - undifferentiated tissue of pereiopod (P) and gill anlagen (Gi) surrounded by the lateral branchiostegites; $\mathbf{h}$ - close-up of undifferentiated tissue of a pereiopod anlage. Abbreviations: Bst - epithelium of branchiostegite, DA - descending artery, DEM - extensor muscle, DG - digestive gland, Gi - gill, H - heart, HG - hindgut, Mxp1 - first maxilliped, Mxp2 - second maxilliped, P - pereiopod anlagen 1 - 5, PA - posterior artery, PoC - posterior caecum, TG - thoracic ganglia, VFM - flexor muscle, VNC - ventral nerve cord 
Table 2 Book chapters and reviews summarizing the internal anatomy of adult decapod crustaceans

\begin{tabular}{|c|c|}
\hline \multicolumn{2}{|l|}{ Organ system } \\
\hline General anatomy & $\begin{array}{l}\text { McLaughlin } 1983 \text { [168], Bell and Lightner } 1988 \text { [169], Felgenhauer 1992a [105], } \\
\text { Forest } 1994 \text { [170], Vogt } 2002 \text { [171], Davie et al. } 2015 \text { [73] }\end{array}$ \\
\hline Digestive system & $\begin{array}{l}\text { Dall and Moriarty } 1983 \text { [69], Icely and Nott } 1992 \text { [70], Factor } 1995 \text { [172], Brösing } 2010 \\
\text { [173], Watling } 2013 \text { [174], Saborowski } 2015 \text { [175], McLay and Becker } 2015 \text { [176] }\end{array}$ \\
\hline Vascular system, circulation, hematopoetic tissues, haemolymph & $\begin{array}{l}\text { Martin and Hose } 1992 \text { [177], } 1995 \text { [178], Söderhäll \& Söderhäll } 2001 \text { [179], Lin } \\
\text { and Söderhäll } 2011 \text { [180], Wirkner and Richter } 2013 \text { [101], Wirkner et al. } 2013 \\
\text { [181], Mac Gaw and Reiber } 2015 \text { [182], Terwilliger } 2015 \text { [183], Söderhäll } 2016 \text { [184], }\end{array}$ \\
\hline Gas exchange, ion regulation, excretion & $\begin{array}{l}\text { Mantel and Farmer } 1983 \text { [185], McMahon and Wilkens } 1983 \text { [186], Taylor and Taylor } \\
1992 \text { [106], McMahon } 1995 \text { [187], Péqueux 1995[107], Charmantier et al. } 2009 \text { [188], } \\
\text { Wirkner and Richter } 2013 \text { [101], Lignot and Charmantier } 2015 \text { [78] }\end{array}$ \\
\hline Endocrine organs, glands and secretion & Cooke and Sullivan 1982 [189], Fingerman 1992 [190], Webster 2015 [191, 192] \\
\hline Integument, setae and chromatophores & $\begin{array}{l}\text { Felgenhauer } 1992 \text { [193], Horst and Freemann } 1993 \text { [194], Dillaman et al. } 2013 \text { [195], } \\
\text { Garm and Watling } 2013 \text { [196], McNamara and Milograna } 2015 \text { [197] }\end{array}$ \\
\hline Connective tissue & Mellon 1992 [198] \\
\hline Muscle and neuromuscular system & $\begin{array}{l}\text { Govind and Atwood } 1982 \text { [199], Chapple } 1982 \text { [200], Mellon } 1992 \text { [198], Govind } \\
1995 \text { [201], Atwood } 2014 \text { [202], Medler and Mykles } 2015 \text { [203], Mykles and Medler } \\
2015 \text { [204] }\end{array}$ \\
\hline Eyes & $\begin{array}{l}\text { Strausfeld and Nässel } 1981 \text { [205], Shaw and Stowe } 1982 \text { [206], Stavenga and } \\
\text { Hardie } 1989 \text { [207], Warrant and Nilsson } 2006 \text { [208], Glantz 2014 [209] }\end{array}$ \\
\hline Chemosensory, mechanosensory, and other sensory organs & $\begin{array}{l}\text { Ache } 1982 \text { [210], Bush and Laverack } 1982 \text { [211], Govind } 1992 \text { [212], Atema and } \\
\text { Voigt } 1995 \text { [213], Breithaupt and Thiel } 2011 \text { [214], Hallberg and Skog } 2011 \text { [114], } \\
\text { Boxshall and Jaume } 2013 \text { [215], Garm and Watling } 2013 \text { [196], Derby and Weissburg } \\
2014 \text { [216], Mellon } 2012 \text { [217], } 2014 \text { [218], Lenz and Hartline 2014 [219], Lohmann } \\
\text { and Ernst } 2014 \text { [220] }\end{array}$ \\
\hline Central nervous system & $\begin{array}{l}\text { Sandeman } 1982 \text { [221], Govind } 1992 \text { [212], Sandeman et al. } 1992 \text { [222], Harzsch } \\
\text { et al. } 2012 \text { [124], Strausfeld } 2012 \text { [223], Loesel et al. } 2013 \text { [224], Sullivan and } \\
\text { Herberholz } 2013 \text { [125], Schmidt } 2016 \text { [127], Sandeman et al. } 2014 \text { [126], Harzsch } \\
\text { and Krieger } 2018 \text { [86] }\end{array}$ \\
\hline Reproductive system & Krol et al. 1992 [227], Talbot and Helluy 1995 [226], Lopez Greco 2013 [225] \\
\hline
\end{tabular}

stomach, where the filter press, a complex filtration system made of setae and ampulla, is located. A complex filter press is already present in the Zoea I of C. maenas (data not shown). Similar observations were made for the first zoeal stages of the decapod species Maja brachydactyla [89], Uca vocator, and Panopeus occidentalis [90], which also possess a well-developed pyloric filter. On the contrary, early life history stages of other brachyuran species were reported to possess a less well-developed pyloric filter system in early zoeal stages (Ucides cordatus, [91]; Dyspanopeus sayi, [92]), and a pyloric filter appears to be absent in the facultative lecitotrophic larval stages of Sesarma curacaoense, which use reserves stored in a yolk sac for nutrition during their pelagic phase [93]. These studies collectively indicate that a well-developed pyloric filter may be an important adaptation for processing and mixing soft food particles suggesting that the gastric anatomy closely mirrors the food spectrum of a crustacean larva. At the same time, it has to be noted that the studies cited above used different methods to analyse the larval digestive systems so that we may be well advised to repeat some of these analyses using histological sections of plastic embedded specimens to standardize the methods.

\section{Digestive gland}

As in adult brachyurans, in the zoeal stages the liquid food that has passed through the filter press enters the midgut via two lateral openings towards the paired lobes of the digestive gland (also called the hepatopancreas or midgut gland). In adults, this complex glandular system is composed of numerous blindly ending tubules and is one of the largest components of the digestive system. It is involved in food absorption and transport, secretion of digestive enzymes, and storage of lipid, glycogen and a number of minerals (for reviews see Table 2). In the zoeal stages of $C$. maenas analysed here, the system is much less complex than in adults and consists of lobes (rather than tubules) that surround a central lumen. The digestive gland is already present at hatching (confirmed by micro-CT analysis). In the Zoea I and II, the digestive gland is nearly spherical in shape and possesses small protruding lobes. During development, these lobes enlarge gradually giving the organ a more and more complex appearance. In adult decapods, the tubules of the digestive gland consist of four cell types: E- (embryonic), F- (fibrillary), R(resorptive), and B- (blister like) cells [71]. E-cells are located at the ends of the tubules and most likely act as 
precursor cells for the remaining three cell types, although there is not any consensus yet about the developmental sequence of cell transformation (compare $[94,95,71])$. We identified the four cell types in the midgut gland of the C. maenas Zoea IV, indicating a high degree of differentiation of this system in response to the diverse planktotrophic diet. The most conspicuous cell type seen in our histological sections were the $\mathrm{R}$-cells that we identified based on their characteristic large lipid inclusions. These inclusions were even visible in intact specimens as orange droplets underneath the dorsal carapace and in the micro-CT analyses of all zoea stages. In our experiments, ad libitum Artemia sp. nauplii were offered as food. Thus they were able to accumulate substantial lipid reserves within their R-cells. Cells with large amounts of lipid inclusions in the medial portions of the digestive gland were also found in larvae of Paralithodes camtschaticus (Lithodoidea; [96]). In addition, the size and quantity of lipid droplets that $P$. camtschaticus larvae accumulated depended on the quality and type of food, as well as on rearing conditions (i.e. water temperature and illumination). Furthermore, similar abundant lipid inclusions within R-cells were also reported in early developmental stages of the American lobster Homarus americanus (Homarida; $[97,98])$. In larvae of the spider crab Hyas araneus (Brachyura), the lipid inclusions in R-cells of the digestive gland show most distinct changes in ultrastructure in response to feeding regime. Therefore, they are an important indicator of the larval nutritional state [72] so that we conclude that the ad libitum feeding regime during our experiments caused an excellent nutritional state of the larvae as witnessed by the massive lipid accumulation.

\section{Musculature \\ Muscles of the cephalothoracic appendages}

All zoeal instars of $C$. maenas displayed a prominent mandibular adductor muscle associated with the mandibles similar to Cancer anthonyi larvae [21]. This distinct muscle is responsible for inward movement of the mandible and hence for macerating food items that will then be further grinded with the gastric mill that shreds the food into even smaller particles. The exopods of the first and second maxillipeds have a natatory function in the zoeal stages, are equipped with long setae and contain elaborate intrinsic musculature. These exopods are lost during the first metamorphosis [60] and the maxillipeds become part of the feeding apparatus of the megalopa stage.

\section{Muscles of the pleon}

The extensor and flexor muscles within the pleon were already described by Trask [21] in the Megalopa of $C$. anthonyi in which it serves to flex and extend the pleon. As previously described for C. maenas [99] and supported by the present study, these muscles are already present in the earlier zoeal stages showing that the ability to flex the pleon is important for these early life history stages. Live observations of the feeding and swimming behaviour in larval stages of porcellanid crabs showed that zoeae catch living prey with the endopods of the maxillipeds and hold it with the flexed pleon and telson [100]. Furthermore, zoeae flip their pleon as an escape reflex (personal observations; and [3]) much like the caridoid escape reaction as described e.g. for adult Astacida or Homarida ("tail flip"). Well-developed dorsal extensor muscles and ventral flexor muscles are essential both for feeding in the zoeal stages and for swimming in the megalopa stage. The swimming appendages of the pleon, the pleopods, and their intrinsic muscles gradually develop in the successive zoeal stages and the Megalopa swims by beating the pleopods [100], a function which in the zoeal stages is accomplished by the exopods of maxillipeds one and two.

\section{Heart and circulatory system}

Adult decapod crustaceans possess an open circulatory system in which the heart pumps the haemolymph via arteries across tissue spaces between the organs, the haemolymph lacunar system. After the passage across the respiratory organs, sinuses channel the haemolymph back towards the pericardium (for references see Table 2). In adult Brachyura, the dorsally located heart is a muscular chamber (also called ventricle), which is suspended by elastic ligaments within a second chamber, the pericardial cavity. The haemolymph enters the heart through paired ostia, three pairs in the case of Brachyura [73]. The ventricle pumps the haemolymph into five main arteries that target the major organ complexes: an unpaired anterior aorta (median brain and eyestalk neuropils), an unpaired posterior aorta (pleon), an unpaired descending artery (ventral nerve cord and thoracic limbs), and paired anterolateral arteries (digestive system, antennal glands). These vessels branch into fine capillaries that supply the target tissues.

Some major components of the adult brachyuran circulatory system such as heart, anterior and posterior aorta, and descending artery were already identified in Megalopae of C. anthonyi [21] and C. maenas [24]. Our results confirm these findings for the Zoea IV of $C$. maenas. In addition, we identified components of the haemolymph lacunar system. Furthermore, we traced previously not identified features of the arterial system in the Zoea IV, namely the cor frontale, a myoarterial formation known from many adult decapod crustaceans and specifically from Brachyurans which acts as an auxiliary heart [74]. This structure represents an aortic 
dilation with its own intrinsic muscles and functions in stabilizing the haemolymph flow towards the median brain and eyestalks including the visual neuropils and the compound eyes (review [101]). As in adult decapods [75], in the Zoea IV, the stomatogastric ganglion is located within the cor frontale. The ophthalmic artery leaves the cor frontale anteriorly, then splits into two branches that invade the eyestalks. The cerebral artery ventrally descends from the cor frontale to innervate the median brain. These results suggest that a strong haemolymph supply to the nervous system as well as to the cephalic sensory organs is an important feature already present in larval stages.

In decapod larvae the heart assumes its function during late embryogenesis $[14,28,102,103]$. Our data suggest a gradual growth and increase of complexity of the larval circulatory system that most likely extends into the juvenile stage similar to the penaeid shrimp Metapenaeus ensis [103]. For example, in adult Decapoda, the heart is supported by trabeculae inside [104, 105] but we did not find such structures within the heart of the Zoea IV. Nevertheless, we detected slight constrictions at the ventral wall of the larval heart that might be anlagen of trabeculae.

\section{lon-transporting and respiratory epithelia, excretory systems \\ Gills}

In adult decapods, the gills serve as principal organs for respiration and ion regulation (for references see Table 2). Corresponding to the ground pattern of Brachyura (review [73]), adult C. maenas possess nine pairs of gills (GI - IX): MXP2 - one podobranch (GI), one arthrobranch (GII), MXP 3 - one podobranch (GIII), two arthrobranches (GIV, GV), P1 - two arthrobranches (GVI, VII), P2 - one pleurobranch (GVIII), and P3 - one pleurobranch (GIX). In brachyuran crabs, the anterior gills mostly accomplish gas exchange, whereas the transport epithelia, responsible for osmoregulation are located in the posterior gills (reviews $[106,107])$. There is an increasing interest in the ontogeny of the osmoregulatory system in decapod crustaceans and the ecological implications of larval osmotolerance for aspects such as dispersal, population maintenance and invasive potential of a species [43-45, 108, 79]. The zoeal stages of $C$. maenas do not possess functional gills, only gill anlagen that gradually develop and are visible from the Zoea II onwards [43], [77]. The gill anlagen of the pereiopods one to three become lamellate and functional during the first metamorphosis to the Megalopa, and the other anlagen become functional during the second metamorphic moult $[43,77]$. In C. maenas, only the Zoea I has limited osmoregulatory capacities whereas all other zoeal instars are primarily osmoconformers, which in too low or too high salinities may suffer severe osmotic stress [43]. The Megalopae display a limited capacity to hyper regulate while juvenile and adults are strong osmoregulators and can occupy habitats with low and fluctuating osmolarity. During ontogeny, C. maenas undergoes an osmo-physiological metamorphosis along with the morphological metamorphosis [43]. From a developmental point of view, the seemingly abrupt maturation of the gills during the metamorphic moult, which must be accompanied by changes in the pattern of haemolymph circulation in the entire system, is an interesting point for future research. Furthermore, another question that needs to be addressed is to what extend antennal glands participate in osmoregulation in the zoeal stages.

\section{Branchiostegites}

In adult brachyurans, the branchiostegites function as additional organs to transport gases and ions [78]. In decapod larvae, the epidermis of the branchiostegites has also been shown to act as an ion-transporting epithelium (see above; and [43-45, 79-81]). The brachyuran crab Eriocheir sinensis, in European waters is an invasive species which as an adult can effectively invade freshwater habitats. Contrary to C. maenas zoeal stages, early stages of $E$. sinensis already possess a moderate capacity to hyper-osmoregulate using the inner epithelium of the branchiostegites [44]. The Megalopa of this species is capable of moderately hyper-/hypo-regulating using the filaments of the posterior gills, and the juvenile crab and adults are euryhaline and have strong hyper-/hypo-regulating capacities, also using the posterior gills. These results, for some brachyurans, support the idea of an osmo-physiological metamorphosis between the planktonic zoeal stages, the semi-benthic megalopa stage, and the juveniles, and also indicate that the larval capability to osmoregulate is an essential adaptive trait for population persistence and range expansion.

\section{Antennal glands}

In adult brachyurans, the antennal glands at the base of each second antenna are major excretory organs. Besides excretion, it is generally accepted that they are also involved in the regulation of haemolymph volume, its acid-base balance, and ionic composition (reviews [73, 78]). They consist of a coelomosac that is involved in ultra-filtrating the supplied haemolymph [105]. The ultra-filtrate (or urine) passes through the labyrinth, a compartment composed of spongy tissue for protein and glucose reabsorption. Through the nephridial canal, the urine is then transported into a bladder and discarded through the nephropore at the base of the second antenna. In the crayfish Astacus leptodactylus and the clawed lobster H. gammarus, the larval antennal glands already display all cytological features necessary for a functionality [80, 81, 108]. A similar report is available 
for the palaemonid shrimp Macrobrachium amazonicum [79]. This paired organ and its major substructures are also present at least in the Zoea IV of C. maenas, as well as in adults, and could be recognized by micro-CT analyses and in histological semi-thin sections. We conclude that the antennal gland is already functional at this stage, because also the nephropore is present in the Zoea IV of C. maenas. In brachyuran crustaceans, the ontogeny of the antennal glands and possible functional changes across the double metamorphosis is not yet understood.

\section{Sensory systems}

Brachyuran larvae show behavioural reactions to an impressive range of environmental stimuli including light, odorants, gravity, hydrostatic pressure, currents, temperature, salinity, and food concentration (reviews $[9,10])$. They are also equipped with an array of chemosensory sensilla on their mouthparts to probe the chemistry of pray items [34]. Zoeae utilize combinations of many environmental cues to control their position within in the water column and by distinct vertical migration use tidal currents for off- and onshore transport (reviews $[7,11,12])$. In C. maenas larvae, such circa tidal rhythms were shown to be also driven by endogenous systems [109-111], and the implications of this behaviour for dispersal were analysed in this species [109, 112, 113]. Furthermore, it is well known that brachyuran larvae can detect chemical and tactile cues from the habitat to identify suitable sites for metamorphosis (reviews $[4,7,9,113]$ ).

\section{Compound eye}

The compound eyes are the most conspicuous sensory organs of C. maenas larvae. Larvae hatch with unstalked eyes that possess apposition optics and this general optical design does not change during subsequent development [25]. After the moult to the Zoea II, the compound eyes are positioned on movable stalks. During ontogeny, the number of ommatidia and ommatidial length increases, which coincides with a decreasing interommatidial angle. These findings suggest a gradual increase of visual performance in terms of resolution and sensitivity during larval life and juveniles but not any fundamental change in eye design [25].

\section{Aesthetascs}

Aesthetascs are considered the most important unimodal chemosensory sensilla for distance chemoreception on the first antennae of adult decapod crustaceans (review [86]). In addition, malacostracan crustaceans possess a multitude of bimodal chemo- and mechanosensory sensilla associated with their two pairs of antennae, mouthparts and walking legs. A cluster of olfactory sensory neurons (OSNs) is associated with each aesthetasc. These bipolar neurons extend highly branched outer dendritic segments into the sensillum's shaft and their axons project into the primary olfactory processing centres of the median brain, the deutocerebral chemosensory lobes (also called olfactory lobes). In C. maenas, Zoea IV larvae possess seven of these aesthetascs per antenna [83] and adults between 150 and 280 [86, 114]. Our current understanding is that the cluster of OSNs associated with one aesthetasc represents the animal's full spectrum of functional olfactory receptor proteins and hence determines the olfactory landscape the organism is able to detect. This view suggests that even a Zoea can detect a similar range of odorants as an adult animal and that the increasing number of aesthetascs during ontogeny primarily increases the sensitivity of the olfactory system [86].

\section{Dorsal organ}

The sensory dorsal organ of crustacean larvae is at the dorsal side of the cephalothorax medially between the dorsal spine and the compound eyes. Externally it is marked by several pores, and internally consists of a both sensory cells and gland tissues [115-117]. In decapod larvae, this organ may act as a chemo- or mechano-/baro-receptor and its central pore may be associated with the gland tissue gland but such suggested roles need to be confirmed by functional studies [117]. Using scanning electron microscopy, the dorsal organ in the Zoea I stage of Portunus acuminatus was traced [19]. We were able to recognize the external pores of the dorsal organ. However, our histological methods were not suitable to identify any tissue associated with this organ. Thus, additional methods, such as transmission electron microscopy, are indispensable for further investigations of the cellular composition of the putative dorsal organ of C. maenas larvae.

\section{Statocyst}

Brachyuran crustaceans use statocyst organs within the second antennomer of the first antennae to detect gravity, angular acceleration, and hydrostatic pressure [118121]. The statocyst of the prawn Palaemon serratus is sensitive to vibration and therefore used for sound reception [122]. The statocyst organ consists of sand granules embedded in a gelatinous substance, which is located on top of an array of sensilla at the floor of the statocyst. The sand granules function as a statolith and are renewed after each moult [123]. Little is known about the presence and development of a statocyst in crustacean larvae. The statocyst of the puerulus of Jasus edwardsii does not yet display any anatomical features such as the sensilla, secretory pores, and fluid within the statocyst cavity which are typical of the adult [120]. There is ample evidence from behavioural studies for geotaxis in brachyuran larvae (review in [10]) but the organ to detect gravity has not been identified. Our 
present study suggests a flattened ellipsoid cell accumulation at the base of the first antenna to be the anlage of a statocyst in the Zoea IV of C. maenas. The cell layers surround a small cavity, but a sensory epithelium with sensilla and a statolith could not be found suggesting that the statocyst anlage is not functional yet. Zoeal stages are planktonic and therefore do have little contact with sediment or inorganic granules to take up as statolith as may have been the case for the larvae used in our studies because they were cultured without any sediment. It remains to be explored which organ is used to detect gravity in pelagic larvae.

\section{Central nervous system and neuroendocrine system Central nervous system}

The general structure of the crustacean central nervous system (CNS) (reviews [124, 125]) and specifically the architecture of the brain (reviews $[86,126,127]$ ) is well understood in reptantian crustaceans including C. maenas [128]. Many CNS structures described in adult brachyurans are present in the late zoeal and megalopal stages [24]. Our micro-CT analysis now extend these descriptions for the Zoea I. Together with data presented for the Zoea I of Pachygrapsus marmoratus [30], our data on $C$. maenas suggest that already at hatching, the brachyuran CNS displays a remarkable degree of complexity and thus is able to perform sophisticated processing tasks. Nevertheless, the neuropils of thoracic neuromeres that are associated with non-functional limb anlagen in the zoeal stages, show strong postembryonic growth (e.g. [36, 37]). In addition, ganglionic elements tend to fuse and condense in larval and juvenile stages (review [84]) in the ontogenetic process of carcinization [73]. In addition to neuropil growth that characterizes the median brain [37], new neurons are also added to the ventral nerve cord during larval development [36, $38]$, as well as the visual neuropils [36, 41], and the olfactory pathway as determined by the use of mitosis markers [37].

\section{Neuroendocrine system}

Organs that are known to be of major importance for endocrine and neuroendocrine regulation during embryonic and larval development in reptantian crustaceans include the Y-organ, the mandibular organ, and the $\mathrm{X}$-organ/sinus gland complex within the eyestalks (reviews [3, 129]). Our histological methods are not well suited to identify the developing neuroendocrine organs of the eyestalk. Nevertheless, by immunohistochemical localization of neuropeptides (moult-inhibiting hormone), some structural aspects of the X-organ/ sinus gland complex in $C$. maenas larvae were described [130, 131]. Furthermore, following a previous anatomical description [82], we were able to identify the Y-organ. In adult decapods, this organ is described as a paired, spindle shaped gland anterior to the junction of the branchial and pre-branchial chamber, closely associated with the epidermis and surrounded by hemocoel [132], a description that closely fits to the structure which we identified as the Y-organ in the Zoea IV. The Y-organ was suggested to promote the proecdysis by release of ecdysteroid hormones [129], and is modulated by the release of moult-inhibiting hormones of the X-organ-sinus gland complex, the major neuroendocrine centre [3]. Collectively, these findings indicate that anlagen of all major neuroendocrine and hormonal organs of reptantian crustaceans are most likely present already at hatching $[3,129,130]$.

\section{Advantages of multimethodological approaches}

In our study, the combination of different methods facilitated the coherent analysis of the larval anatomy. The detection of auto-fluorescence has proven to be a fast and cost-efficient method assessing external morphology (e.g., [35, 133]) and allows to document specimens under high resolution without introducing artefacts by additional preparation steps. Furthermore, in contrast to techniques such as scanning electron microscopy the specimens can be used for additional histological experiments after imaging, and even anatomical details below the cuticle can be detected [133].

We showed that using micro-CT provided enough resolution for recognizing the most important organ systems in C. maenas larvae and to visualize their gross anatomy. Most importantly, micro-CT allows for reconstructing the spatial relationships of organ systems [134]. Our data demonstrate that this technique facilitates the anatomical analysis even of small arthropods and therefore provides a promising extension to the methodological spectrum used in previous studies on brachyuran larvae. The generation of anatomical atlases in invertebrates is traditionally based on serial sectioning of dissected tissues or entire organisms. This is a time-consuming procedure prone to artefacts such as section loss, distortion, and staining artefacts. Therefore, we suggest that non-invasive approaches such as micro-CT are likely to more accurately reflect the spatial arrangement of certain organs compared with invasive techniques and should therefore be favoured [134] although micro-CT analyses are prone to a certain amount of tissue shrinkage during the drying process [135]. Furthermore, obtaining micro-CT data is fast so that in the future we may be able to analyse organogenesis including volumetric data in larger numbers of specimens that were exposed e.g. to different experimental treatments during rearing.

Different tissues might possess equal X-ray densities and thus equal grey values in tomographies, which might 
hinder discrimination. In such cases, more details can be obtained by analysing semi-thin histological sections with a high resolution. This approach is time consuming but can complement micro-CT analyses in order to gain anatomical information down to the single-cell level [25]. For example, in our study, histology provided solid information on different cell types of the digestive system, which was not possible with micro-CT. Finally, immunohistochemistry provides yet another tool to analyse details of specific cell types such as ionocytes in the developing gills [43] or specific neuronal populations within the central nervous system [41, 42].

\section{Conclusions}

The combination of imaging techniques used in the present study provided additional insights into the bewildering diversity of organ systems that larvae possess, which are necessary for autonomously surviving and developing in the plankton. This rich organ repertoire is crucial for generating adaptive behaviours and responding to variations in environmental key factors such as light, hydrostatic pressure, tidal currents, temperature, salinity, and food concentration (reviews $[9,7,10]$ ). Arguably, the histological complexity and behavioural repertoire of zoeae may be viewed as exceeding that of other arthropod larvae, e.g. those of holometabolous insects such as the vinegar fly Drosophila melanogaster and that of other crustaceans such as copepods which are in the same size range as adults.

Much of our fascination for the anatomy of brachyuran larvae stems from the opportunity to observe a complete and complex organism on a single microscopic slide and the realization that the entire decapod crustacean bauplan does unfold from organ anlagen compressed into a miniature organism in the sub-millimetre range. Despite their different life styles and outer morphology, brachyuran larvae are smaller versions of the adults when considering their inner organization. Along these lines, Trask [21] concluded that: "The major difference between the first, intermediate and last larval forms is basically one of size of the various systems involved, rather than absolute complexity".

Despite the numerous examples for a seemingly gradual development of organ systems across the double metamorphosis that we discussed here, several of the metamorphic processes may nevertheless be promising targets for future investigations by developmental biologists:

- How is the musculature of the pereiopods refined during the seemingly abrupt transition to functionality during the first metamorphosis?

- Which processes in the central nervous system coincide with the maturation of the neuromuscular system in the pereiopods?
- How do the gills associated with the pereiopods become functional and supplied with haemolymph by the circulatory system during the first metamorphosis?

- Do the antennal glands change their function as the gills start functioning as osmoregulatory structures after the first metamorphosis?

Contrary to holometabolous insects for example, these metamorphic transformations must occur "on the fly" in an organism that autonomously must find food, that is constantly exposed to predation and must respond to tidal currents. For many decades, brachyuran larvae have served as distinguished models in the field of Ecological Developmental Biology (reviews [4, 7]). Our study may provide a means to link such ecophysiological studies to the level of tissues and organs.

\section{Methods}

\section{Handling of berried females and larval rearing}

Berried females of the European shore crab Carcinus maenas Linnaeus, 1758 (Decapoda, Brachyura, Portunidae), were collected at the western intertidal of the island of Helgoland (Germany) during their reproductive period. To avoid possible acclimation effects to laboratory conditions, only females with eggs in late embryonic stages (dark grey-brown coloured) were chosen thus ensuring that most of the embryonic development occurred within the natural habitat. Females were transported to the Biologische Anstalt Helgoland (BAH) of the Alfred Wegener Institute, Helmholtz Centre for Polar and Marine Research (Germany). They were kept at $18{ }^{\circ} \mathrm{C}$ in individual, aerated $20 \mathrm{~L}$ aquaria, filled with natural seawater, corresponding to the conditions in their native habitat in summer. Females were fed twice a week with frozen shrimps (Crangon crangon) and the water was changed daily in order to ensure high water quality at hatching. After hatching, freshly hatched larvae (Zoea I) were transferred to $400 \mathrm{ml}$ glass-bowls (50 animals per bowl) filled with filtered natural seawater and kept at $18{ }^{\circ} \mathrm{C}$ [43]. Larval numbers were decreased after each successive stage, Zoea II, III, IV and Megalopa, to 40, 30, 20, and ten individuals per bowl, respectively, to account for growth. Water and food (freshly hatched Artemia sp. nauplii ad libitum) were exchanged daily. During each water change, dead larvae were discarded and moulted larvae were transferred to a separate bowl to ensure that the sampled larvae were at the same instar. Each larval stage was sampled at intermoult (i.e. when $50 \%$ of each moult cycle had occurred) according to preliminary data on larval developmental times (F. Spitzner, unpublished data).

\section{Imaging of cuticular autofluorescence}

For autofluorescence imaging, Zoea IV were fixed in $70 \%$ ethanol and stored within the fixative until further 
use. For microscopic analysis, single larvae were transferred onto microscopic slides, submersed in fresh ethanol and cover slipped using modelling clay as spacers. Whole mounts were viewed using a Nikon Eclipse 90i upright microscope equipped with a digital camera by using appropriate filter sets (excitation 359-371 nm; emission $379 \mathrm{~nm}$ ).

\section{Preparation for X-ray micro-computed tomography}

For reconstructions of the internal anatomy using X-ray micro-computed tomography (micro-CT), specimens of each zoeal stage were fixed in Bouin's solution (saturated aqueous picric acid, concentrated acetic acid and $10 \%$ formaldehyde solution) and stored in the fixative until further analysis. To ensure adequate fixation, the dorsal and rostral spines, as well as the pleon were dissected. For micro-CT analysis, samples were processed according to [134]. Fixed specimens were washed three times in sodium hydrogen phosphate buffer (0.1 M Roti fair PBS pH 7.2 [Carl Roth] with $1.8 \%$ sucrose) and dehydrated via a graded ethanol series. Afterwards, samples were incubated overnight in a $1 \%$ iodine solution (iodine, resublimated [Carl Roth \#X864.1] in 99.8\% ethanol) and washed three times in ethanol (99.8\%). Specimens were critical point dried with an automated dryer Leica EM CPD300 (Leica Microsystems GmbH, Wetzlar, Germany) and subsequently fixed on insect needles with hot glue. The samples were scanned with an Xradia MicroXCT-200 X-ray imaging system (Carl Zeiss Microscopy $\mathrm{GmbH}$ ). Tomographic scans were obtained using a 10x magnification lens unit with $\mathrm{X}$-ray source settings at $40 \mathrm{kV}$ and $200 \mu \mathrm{A}$, and with $1.5 \mathrm{~s}$ acquisition time. The reconstruction of tomography projections was processed by using the XMReconstructor software, resulting in tiff-format image stacks.

\section{Three-dimensional reconstruction}

Segmentation and volume rendering of image stacks was performed by using the software Amira 5.4.5 and Amira 5.6.0 (FEI Visualization Science Group, Burlington, USA). Overall, three replicates of each zoeal stage were analysed in order to render the volume of the nervous system, digestive tract, heart and musculature. Using every second slide, the respective organ system of each zoeal stage was reconstructed as described by in [134]. Afterwards, volume renderings were performed by using the "Volren" function. For images of the dorsal organ, a volume rendering, generated with the "Volren" function of Amira, of the outer surface of a Zoea IV was used.

\section{Semi-thin sectioning}

For histological sections, larvae of the fourth stage were immersed in FAE (80\% ethanol, 37\% formalin, pure acetic acid), following dissection of limbs and pleon, and stored in the fixative until further analysis. After washing in several changes of PBS (0.1M, pH7.2, 1.8\% sucrose), specimens were post fixed for 1 hour in osmium tetroxide. After washing in three changes $(20 \mathrm{~min}$. each) of PBS, specimens were transferred to $30 \%$ acetone and dehydrated through an ascending series of acetone to $100 \%$. The dehydrated samples were transferred to a 1:1 mixture of acetone: araldite (Araldite epoxy resin kit, Agar Scientific) overnight. The larvae were then embedded in pure araldite and incubated for 2 days at $60{ }^{\circ} \mathrm{C}$ for polymerization. Embedded larvae were sectioned (1.5 $\mu \mathrm{m})$ with a Hyrax S50 vibratome (Zeiss). Finally, sections were stained after Holländer and Vaaland [136] with a solution of $1 \%$ phenylendiamin in methanol-isopropanol for 12h. Afterwards, the slides were covered with Roti ${ }^{\ominus}$-Histokitt and cover slips. Sections were viewed using Nikon Eclipse 50 and 90i upright microscopes equipped with a digital camera (Nikon Digital Sight DS 2MBWc). The section plane of the selected sections in Figs. 9, 10, $11,12,13,14,15,16$ and 17 is shown in Fig. 2c.

\section{Nomenclature}

If not otherwise indicated, we will use the general anatomical nomenclature as proposed in publications [3] and [73]. The central nervous system has already been described in some detail for the Megalopa of C. maenas [24]. Because the general layout of the nervous system in the zoea stages resembles that of the Megalopa (Figs. 5 and 6), we will use the nomenclature proposed in [24] with significant modifications according to [84-86].

\section{Abbreviations}

A1: first antenna; A2: second antenna; AA: anterior aorta; AC: anterior caeca; ADC: anterior dorsal cells of the protocerebrum; AES: aesthetasc; AG: antennal gland; AGM: anterior gastric muscles; AL: anterior lobe; AR: ampullary ridge; ASS: ampullary setal screen of the gland filter; Ax: axon; B: blister like cell; BI: bladder; Br: median brain; BSt: epithelium of branchiostegite; CA : cerebral artery; Cap: capillary; CB: central body; CEC: circumoesophageal connective; CF: cor frontale; CFM: cor frontale muscle; CG: commissural ganglion;

$\mathrm{CL}$ : corneal lens; CMsc : contractor muscles of cardiac stomach; Co: cornea of compound eye; CoeSac: coelomosac; Cry: crystalline cone; CS: cardiac stomach; CSac: cardiac sac; Cu: cuticle; CV: cardio-pyloric valve; DA : descending artery; Da: dactylus (in Fig. 2); DC: Deutocerebrum; DCL: deutocerebral chemosensory lobes; De: dendrites; DEM: dorsal extensor muscles; DG: digestive gland;

DGM: dorsal gastric muscles; DL: dorsal lobe; DLC: dorsolateral pyloric channel; DMsc: dilatator muscle of esophagus; DP: distal pigment; DPC: dorsal region of the pyloric chamber; DPF: dorsal pyloric fold; DS: dorsal spine; E : embryonic cell; Eso: oesophagus; Ey: compound eye; Ey stalk: eyestalk; EyNP: eyestalk neuropil; F: fibrillary cell; FG: foregut; FP: filter press; Gi: gill; $\mathrm{H}$ : heart; $\mathrm{HG}$ : hindgut; HN/TM: complex of hemiellipsoid body neuropil and medulla terminalis; HPT: hematopoietic tissue; IAR: interampullary ridge; IP: incisor process; La : lamina; LAC: lower ampullary chamber; Lb: labrum; Lo: lobula; LT: lateral tooth; Lu: lumen of the digestive gland; Ly: Labyrinth; MA: mandibular adductor muscles; Md: mandible; MdP: mandibular palp; Me: medulla; MG: midgut; MP: molar process; Msc: musculature; MT: median tooth; Mx1: first maxilla; Mx2: second maxilla; Mxp1: first maxilliped; Mxp2: second maxilliped; Mxp3: third maxilliped; Neu: neurites; No: nephropore; NP: neuropil; O : Ostium; OA: ophthalmic artery; Om: ommatidium of compound eye; OSN: olfactory sensory neurons; P: pereiopods or pereiopod anlagen; PA: posterior aorta; PC: protocerebrum; PCav: pericardial cavity; PCT: protocerebral tract; PI: shielding pigment; PI: pleopod anlagen; PLG: pleon ganglia; PLM: pleopod musculature; PM: pleomere; PNT : projection neuron tract; PoC: posterior 
caecum; PosL: posterior lobe; PPO: prepyloric ossicle; Pr: propodus; PS: pyloric stomach; PSS: pyloric setal screen; R: resorptive cell; Re: retina; Rh: rhabdom of photoreceptor cell; Ros: rostrum; RS: rostral spine; SA: sternal artery; SEG: suboesophageal ganglia; St : putative anlage of the statocyst; StG: stomatogastric ganglion; StN: stomatogastric nerve; T: thoracomere; TC: tritocerebrum; TeG: tegumental glands; TG 1-5: thoracic ganglia one to five; Tr: primary trabeculae; UAC: upper ampullary chamber; VFM: ventral flexor muscles; VGM: ventral gastric muscles; VL: ventral lobe; VNC: ventral nerve cord; Y: Y-organ

\section{Acknowledgements}

We wish to thank the students of the "Schülerlabor" on Helgoland for their help in collecting and maintaining adult crabs at the Biologische Anstalt Helgoland (Alfred Wegener Institute, Helmholtz Centre for Polar and Marine Research, Helgoland, Germany). Jakob Krieger is gratefully acknowledged for performing the micro-CT scans. We dedicate this paper to Klaus Anger and Ralph R. Dawirs who lead the way towards establishing C. maenas larvae as a model in ecological developmental biology.

\section{Funding}

This study was supported by the DFG Research Training Group 2010 RESPONSE and DFG INST 292/119-1 FUGG, DFG INST 292/120-1 FUGG. These funding bodies did not influence the design of the study and collection, analysis, and interpretation of data nor the writing of the manuscript.

\section{Availability of data and materials}

The datasets used and/or analysed during the current study are available from the corresponding author on reasonable request.

Once this manuscript is considered for publication, the micro-CT datasets generated and/or analysed during the current study will be made available in the MorphDBase repository at https://www.morphdbase.de/

\section{Authors' contributions}

GT and SH conceived this study and AS participated in designing the experiments. FS and GT reared the experimental animals in the laboratory, and RM, CK and SE assisted in animal rearing. FS carried out the histological experiments and microscopic analysis and compiled the figures. SH participated in the microscopic analysis. CK, EN and SE generated the 3D reconstructions using Amira. FS and SH drafted the manuscript. GT, RM and AS helped drafting the manuscript. All authors read and approved the final manuscript.

\section{Ethics approval and consent to participate}

The research presented in this paper complies with the guidelines from the directives 2010/63/EU of the European parliament and of the Council of 22nd September 2010 on the protection of animals used for scientific purposes.

\section{Competing interests}

The authors declare that they have no competing interests.

\section{Publisher's Note}

Springer Nature remains neutral with regard to jurisdictional claims in published maps and institutional affiliations.

\section{Author details}

${ }^{1}$ Zoological Institute and Museum, Department of Cytology and Evolutionary Biology, Universität Greifswald, D-17498 Greifswald, Germany. ${ }^{2}$ Alfred Wegener Institute, Helmholtz Centre for Polar and Marine Research, Biologische Anstalt Helgoland, D-27498 Helgoland, Germany. ${ }^{3}$ Department of Ecology, Environment and Plant Sciences, Stockholm University, Svante Arrhenius väg 20A/F, 11418 Stockholm, Sweden.

Received: 8 April 2018 Accepted: 30 May 2018

Published online: 06 July 2018

\section{References}

1. Williamson DI. Larval morphology and diversity. In: Abele LG, editor. The Biology of Crustacea: 2. Embryology, morphology and genetics. New York: Academic press; 1982. p. 43-110.
2. Ingle RW. Larval stages of north-eastern Atlantic crabs: an illustrated key. London: Chapman \& Hall; 1992

3. Anger K. The Biology of Decapod Crustacean Larvae. 1st ed. Lisse: A.A. Balkema Publishers; 2001.

4. Anger K. Contributions of larval biology to crustacean research: a review. Invertebr Reprod Dev. 2006:49:175-205.

5. Martin JW, Olesen J, Hoeg JT. Atlas of Crustacean Larvae. Maryland: JHU Press; 2014.

6. Haug JT, Haug C. "Crustacea": Comparative aspects of larval development. In: Wanninger A, editor. Evolutionary Developmental Biology of Invertebrates 4. Vienna: Springer; 2015. p. 63-100.

7. Anger K, Queiroga H, Calado R. Larval development and behaviour strategies in Brachyura. In: Castro P, Davie PJF, Guinot D, Schram FR, von Vaupel Klein JC, editors. Treatise on Zoology-Anatomy, Taxonomy, Biology. The Crustacea, Vol.9, part C-I, Decapoda: Brachyura. Leiden, Boston: Brill; 2015. p. 317-74

8. Giménez L. Potential effects of physiological plastic responses to salinity on population networks of the estuarine crab Chasmagnathus granulata. Helgoland Marine Research. 2003;56:265-73.

9. Forward RB Jr. Larval Biology of the Crab Rhithropanopeus harrisii (Gould): A Synthesis. Biol Bull. 2009;216:243-56.

10. Epifanio CE, Cohen JH. Behavioural adaptations in larvae of brachyuran crabs: A review. J Exp Mar Bio Ecol. 2016;482:85-105.

11. Cronin TW, Forward RB. Vertical migration cycles of crab larvae and their role in larval dispersal. Bul Mar Sci. 1986;39:192-201.

12. Cohen JH, Forward RB Jr. Zooplankton diel vertical migration - a review of proximate control. In: Gibson RN, Atkinson RJA, Gordon JDM, editors. Oceanography and Marine Biology: An Annual Review 47. Boca Raton: CRC Press; 2009. p. 77-110.

13. Forward RB, Tankersley RA, Rittschof D. Cues for Metamorphosis of Brachyuran crabs: An Overview. Am Zool. 2001;41:1108-22.

14. Schiffer M, Harms L, Lucassen M, Mark FC, Pörtner HO, Storch D. Temperature tolerance of different larval stages of the spider crab Hyas araneus exposed to elevated seawater $\mathrm{P} \mathrm{CO}_{2}$. Front Zool. 2014;11:87.

15. Jirikowski GJ, Wolff C, Richter S. Evolution of eumalacostracan development-new insights into loss and reacquisition of larval stages revealed by heterochrony analysis. EvoDevo. 2015;6:4.

16. Rice AL. Crab zoeal morphology and its bearing on the classification of the Brachyura. Trans Zool Soc Lond. 1980;35:271-424.

17. Factor JR. Development and Metamorphosis of the Digestive System of Larval Lobsters, Homarus americanus (Decapoda: Nephropidae). J Morphol. 1981;169:225-42.

18. Meyer R, Melzer RR. Scanning EM diagnosis of marine Decapoda larvae: a comparison of preparation techniques. Crustaceana. 2004;77:883-6.

19. Meyer R, Wehrtmann IS, Melzer RR. Morphology of the first zoeal stage of Portunus acuminatus, Stimpson, 1871 (Decapoda: Portunidae: Portuninae) reared in the laboratory. Sci Mar. 2006;70:261-70.

20. Geiselbrecht H, Melzer RR. Mandibles of zoea I larvae of nine decapod species: a scanning EM analysis. Spixiana. 2010;33:27-47.

21. Trask T. Laboratory-reared larvae of Cancer anthonyi (Decapoda: Brachyura) with a brief description of the internal anatomy of the megalopa. Mar Biol. 1974;27:63-74

22. Nakamura K. Organogenesis during metamorphosis in the swimming crab Portunus trituberculatus. Nippon Suisan Gakk. 1990;56:1561-4.

23. Factor JR. Development and Metamorphosis of the Feeding Apparatus of the Stone Crab Menippe mercenaria (Brachxura, Xanthidae). J Morphol. 1982; 172:299-312.

24. Harzsch S, Dawirs RR. On the morphology of the central nervous system in larval stages of Carcinus maenas L. (Decapoda, Brachyura). Helgoländer Meeresunters. 1993;47:61-79.

25. Harzsch S, Dawirs RR. Maturation of the compound eyes and eyestalk ganglia during larval development of the brachyuran crustaceans Hyas araneus L. (Decapoda, Majidae) and Carcinus maenas L. (Decapoda, Portunidae). Zoology. 1996;99:189-204.

26. Rotllant G, Charmantier-Daures M, Trilles JP, Charmantier G. Ontogeny of the sinus gland and of the organ of Bellonci in larvae and postlarvae of the European lobster Homarus gammarus. Invertebr Reprod Dev. 1994;26:13-22.

27. Rotllant G, Charmantier-Daures M, De Kleijn D, Charmantier G, Van Herp F. Ontogeny of neuroendocrine centres in the eyestalk of Homarus gammarus embryos: an anatomical and hormonal approach. Invertebr Reprod Dev. 1995;27:233-45 
28. Helluy SM, Ruchhoeft ML, Beltz BS. Development of the olfactory and accessory lobes in the American lobster: an allometric analysis and its implications for the deutocerebral structure of decapods. J Comp Neuro. 1995:357:433-45.

29. Lignot JH, Susanto GN, Charmantier-Daures M, Charmantier G. Immunolocalization of $\mathrm{Na}+\mathrm{K}+$-ATPase in the branchial cavity during the early development of the crayfish Astacus leptodactylus (Crustacea, Decapoda). Cell Tissue Res. 2005;319:331-9.

30. Geiselbrecht H, Melzer RR. Nervous systems in 3D: A comparison of Caridean, anomuran, and brachyuran zoea-I (Decapoda). J Exp Zool B Mol Dev Evol. 2013;320:511-24.

31. Lignot JH, Charmantier G. Immunolocalization of Na+, K+-ATPase in the branchial cavity during the early development of the European lobster Homarus gammarus (Crustacea, Decapoda). J Histochem Cytochem. 2001;49: 1013-23.

32. Ikeda H, Hirano Y, Saigusa M. A pair of rosette glands in the embryo and zoeal larva of an estuarine crab Sesarma haematocheir, and classification of the tegumental glands in the embryos of other crabs. J Morphol. 2004;259: 55-68.

33. Cieluch U, Charmantier G, Grousset E, Charmantier-Daures M, Anger K. Osmoregulation, immunolocalization of $\mathrm{Na}+/ \mathrm{K}+-$ ATPase, and ultrastructure of branchial epithelia in the developing brown shrimp, Crangon crangon (Decapoda, Caridea). Physiol Biochem Zool. 2005;78:1017-25.

34. Geiselbrecht H, Melzer RR. How do mandibles sense?-The sensory apparatus of larval mandibles in Palaemon elegans Rathke, 1837 (Decapoda, Palaemonidae). Arthropod Struct Dev. 2013;42:1-16.

35. Zupo V, Buttino I. Larval development of decapod crustaceans investigated by confocal microscopy: an application to Hippolyte inermis (Natantia). Mar Biol. 2001;138:965-73.

36. Harzsch S, Dawirs RR. Neurogenesis in larval stages of the spider crab Hyas araneus (Decapoda, Brachyura): proliferation of neuroblasts in the ventral nerve cord. Roux' Arch Dev Biol. 1994;204:93-100.

37. Harzsch S, Dawirs RR. Neurogenesis in developing crab brain: postembryonic generation of neurons persists beyond metamorphosis. J Neurobiol. 1996;29:384-98.

38. Harzsch S, Miller J, Benton J, Dawirs RR, Beltz B. Neurogenesis in the thoracic neuromeres of two crustaceans with different types of metamorphic development. J Exp Biol. 1998;201:2465-79.

39. Sullivan JM, Macmillan DL. Embryonic and postembryonic neurogenesis in the ventral nerve cord of the freshwater crayfish Cherax destructor. J Exp Zool A Ecol Genet Physiol. 2001;290:49-60.

40. Meyer R, Martin J, Melzer RR. Nucleus patterns of zoea I larvae (Crustacea: Decapoda) in the context of taxonomy. Zootaxa. 2010;2422:31-42.

41. Harzsch S, Dawirs RR. A developmental study of serotonin-immunoreactive neurons in the larval central nervous system of the spider crab Hyas araneus (Decapoda, Brachyura). Invert Neurosci. 1995;1:53-65.

42. Harzsch S, Dawirs RR. Development of neurons exhibiting FMRFamide-related immunoreactivity in the central nervous system of larvae of the spider crab Hyas araneus L.(Decapoda: Majidae). J Crustacean Biol. 1996;16:10-9.

43. Cieluch U, Anger K, Aujoulat F, Buchholz F, Charmantier-Daures M, Charmantier G. Ontogeny of osmoregulatory structures and functions in the green crab Carcinus maenas (Crustacea, Decapoda). J Exp Biol. 2004;207:325-36.

44. Cieluch U, Anger K, Charmantier-Daures M, Charmantier G. Osmoregulation and immunolocalization of $\mathrm{Na}^{+} / \mathrm{K}^{+}$-ATPase during the ontogeny of the mitten crab Eriocheir sinensis (Decapoda, Grapsoidea). Mar Ecol Prog Ser. 2007;329:169-78.

45. Ituarte RB, Lignot JH, Charmantier G, Spivak E, Lorin-Nebel C. Immunolocalization and expression of $\mathrm{Na}+/ \mathrm{K}+$-ATPase in embryos, early larval stages and adults of the freshwater shrimp Palaemonetes argentinus (Decapoda, Caridea, Palaemonidae). Cell Tissue Res. 2016;364:527-41.

46. Dohle W, Gerberding M, Hejnol A, Scholtz G. Cell lineage, segment differentiation, and gene expression in crustaceans. In: Scholtz G, editor. Evolutionary Developmental Biology of Crustacea. Lisse: AA Balkema Publishers; 2004. p. 95-134.

47. Gerberding M, Patel NH, Stern CD. Gastrulation in crustaceans: germ layers and cell lineages. In: Stern C, editor. Gastrulation: From Cells to Embryo. New York: CSHL Press; 2004. p. 79-89.

48. Harzsch S, Hafner GS. Evolution of eye development in arthropods: Phylogenetic aspects. Arthropod Struct Dev. 2006;35:319-40.

49. Vogt $\mathrm{G}$. The marbled crayfish: a new model organism for research on development, epigenetics and evolutionary biology. J Zool. 2008;276:1-13.
50. Vogt G. Investigation of hatching and early post-embryonic life of freshwater crayfish by in vitro culture, behavioural analysis, and light and electron microscopy. J Morphol. 2008;269:790-811.

51. Jirikowski GJ, Richter S, Wolff C. Myogenesis of Malacostraca-the "eggnauplius" concept revisited. Front Zool. 2013;10:76.

52. Scholtz G, Wolff C. Arthropod Embryology: Cleavage and Germ Band Development. In: Minelli A, Boxshall G, Fusco G, editors. Arthropod Biology and Evolution. Berlin, Heidelberg: Springer; 2013. p. 63-89.

53. Harzsch S, Krieger J, Faulkes Z. "Crustacea": Decapoda - Astacida. In: Wanninger A, editor. Evolutionary Developmental Biology of Invertebrates 4 Ecdysozoa II: Crustacea. Wien: Springer Verlag; 2015. p. 101-52.

54. Hertzler PL. "Crustacea": Decapoda Dendrobranchiata. In: Wanninger A, editor. Evolutionary Developmental Biology of Invertebrates 4: Ecdysozoa II: Crustacea. Wien: Springer Verlag; 2015. p. 63-100.

55. Wolff C, Gerberding M. "Crustacea": Comparative aspects of early development. In: Wanninger A, editor. Evolutionary Developmental Biology of Invertebrates 4: Ecdysozoa II: Crustacea. Wien: Springer Verlag; 2015. p. 39-62.

56. Jirikowski GJ, Vogt G, Charmantier-Daures M, Charmantier G, Harzsch S. Chapter 3: Organogenesis. In: Anger K, Harzsch S, Thiel M, editors. The Natural History of the Crustacea, Volume 7: Developmental Biology and Larval Ecology. Oxford: Oxford University Press. accepted.

57. Roman JOE, Palumbi SR. A global invader at home: population structure of the green crab, Carcinus maenas, in Europe. Mol Ecol. 2004;13:2891-8.

58. Compton TJ, Leathwick JR, Inglis GJ. Thermogeography predicts the potential global range of the invasive European green crab (Carcinus maenas). Divers Distributions. 2010;16:243-55.

59. Tepolt CK, Somero GN. Master of all trades: thermal acclimation and adaptation of cardiac function in a broadly distributed marine invasive species, the European green crab, Carcinus maenas. J Exp Biol. 2014;217:1129-38.

60. Wiliamson HC. On the larval and early young stages and rate of growth of the shore crab (Carcinus maenas, Leach). Rep Fishery Bd Scotl. 1903;19:136-79.

61. Al R, Ingle RW. The larval development of Carcinus maenas (L.) and C. mediterraneus Czerniavsky (Crustacea, Brachyura, Portunidae) reared in the laboratory. Bull Br Mus Nat Hist (Zool). 1975;28:103-19.

62. Dawirs RR. Methodological aspects of rearing decapod larvae Pagurus bernhardus (Paguridae) and Carcinus maenas (Portunidae). Helgoländer Meeresuntersuch. 1982:3:439-64.

63. Mohamedeen $\mathrm{H}$, Hartnoll RG. Larval and postlarval growth of individually reared specimens of the common shore crab Carcinus maenas (L.). J Exp Mar Biol Ecol. 1990;134:1-24.

64. Dawirs RR. Elemental composition $(\mathrm{C}, \mathrm{N}, \mathrm{H})$ in larval and crab-1 stages of Pagurus bernhardus (Decapoda, Paguridae) and Carcinus maenas (Decapoda, Portunidae). Mar Biol. 1980;57:17-23.

65. Dawirs RR. Respiration, energy balance and development during growth and starvation of Carcinus maenas L. larvae (Decapoda: Portunidae). J Exp Mar Biol Ecol. 1983;69:105-28.

66. Dawirs RR. Temperature and larval development of Carcinus maenas (Decapoda) in the laboratory; predictions of larval dynamics in the sea. Mar Ecol Prog Ser. 1985;24:297-302.

67. Dawirs RR, Dietrich A. Temperature and laboratory feeding rates in Carcinus maenas L. (Decapoda: Portunidae) larvae from hatching through metamorphosis. J Exp Mar Biol Ecol. 1986;99:133-47.

68. Dawirs RR, Püschel C, Schorn F. Temperature and growth in Carcinus maenas L. (Decapoda: Portunidae) larvae reared in the laboratory from hatching through metamorphosis. J Exp Mar Biol Ecol. 1986;100:47-74.

69. Dall W, Moriarty DJW. Functional aspects of nutrition and digestion. In: Mantel LH, editor. The Biology of Crustacea. Vol. 5: Internal anatomy and physiological regulation. New York: Academic Press; 1983. p. 215-62.

70. Icely JD, Nott JA. Digestion and absorption: digestive system and associated organs. In: Harrison FW, Humes AG, editors. Microscopic anatomy of invertebrates. Vol. 10, Decapod Crustacea. New York: Wiley-Liss; 1992. p. 147-202.

71. Vogt G. Life-cycle and functional cytology of the hepatopancreatic cells of Astacus astacus (Crustacea, Decapoda). Zoomorphology. 1994;114:83-101.

72. Storch $V$, Anger K. Influence of starvation and feeding on the hepatopancreas of larval Hyas araneus (Decapoda, Majidae). Helgol Meeresunters. 1983;36:67.

73. Davie PJF, Guinot D, Ng PKL. Anatomy and functional morphology of Brachyura. In: Castro P, Davie PJF, Guinot D, Schram FR, von Vaupel Klein JC, editors. Treatise on Zoology-Anatomy, Taxonomy, Biology. The Crustacea, Vol.9, part C-I, Decapoda: Brachyura. Leiden, Boston: Brill; 2015. p. 11-163. 
74. Steinacker A. The anatomy of the decapod crustacean auxiliary heart. Biol Bull. 1978;154:497-507.

75. Chaves da Silva PG, Benton JL, Sandeman DC, Beltz BS. Adult neurogenesis in the crayfish brain: the hematopoietic anterior proliferation centre has direct access to the brain and stem cell niche. Stem Cells Dev. 2012;22: 1027-41.

76. Noonin C, Lin X, Jiravanichpaisal P, Söderhäll K, Söderhäll I. Invertebrate hematopoiesis: an anterior proliferation centre as a link between the hematopoietic tissue and the brain. Stem Cells Dev. 2012;21:3173-86.

77. Hong SY. Development of epipods and gills in some pagurids and brachyurans. J Nat Hist. 1988;22:1005-40.

78. Lignot $\mathrm{JH}$, Charmantier G. Osmoregulation and excretion. In: Chang ES, Thiel M, editors. The Natural History of Crustacea. Vol. 4: Physiology. New York: Oxford University Press; 2015. p. 249-85.

79. Boudour-Boucheker N, Boulo V, Lorin-Nebel C, Elguero C, Grousset E, Anger K, Charmantier-Daures M, Charmantier G. Adaptation to freshwater in the palaemonid shrimp Macrobrachium amazonicum: comparative ontogeny of osmoregulatory organs. Cell Tissue Res. 2013;353:87-98.

80. Khodabandeh S, Charmantier G, Blasco C, Grousset E, Charmantier-Daures M. Ontogeny of the antennal glands in the crayfish Astacus leptodactylus (Crustacea, Decapoda): anatomical and cell differentiation. Cell Tissue Res. 2005;319:153-65

81. Khodabandeh S, Kutnik M, Aujoulat F, Charmantier G, Charmantier-Daures M. Ontogeny of the antennal glands in the crayfish Astacus leptodactylus (Crustacea, Decapoda): immunolocalization of $\mathrm{Na}+, \mathrm{K}+-\mathrm{ATPase}$. Cell Tissue Res. 2005;319:167-74.

82. Hoecker B. Licht-und elektronenmikroskopische Untersuchungen zur Larvalund Juvenilentwicklung der Seespinne Hyas araneus: Decapoda, Majidae unter besonderer Berücksichtigung des Y-Organs. Doctoral dissertation. 1988.

83. Ekerholm M, Hallberg E. Development and growth patterns of olfactory sensilla in malacostracan crustaceans. In: Wiese K, editor. The Crustacean Nervous System. Berlin, Heidelberg: Springer; 2002. p. 376-85.

84. Harzsch S. Ontogeny of the ventral nerve cord in malacostracan crustaceans: a common plan for neuronal development in Crustacea, Hexapoda, and other Arthropoda? Arthropod Struct Dev. 2003;32:17-37.

85. Richter S, Loesel R, Purschke G, Schmidt-Rhaesa A, Scholtz G, Stach T, Vogt L, Wanninger A, Brenneis G, Döring C, Faller S, Fritsch M, Grobe P, Heuer CM, Kaul S, Møller OS, Müller CHG, Rieger V, Rothe BH, Stegner MEJ, Harzsch S. Invertebrate neurophylogeny - suggested terms and definitions for a neuroanatomical glossary. Front Zool. 2010;7:29.

86. Harzsch S, Krieger J. Crustacean olfactory systems: a comparative review and a crustacean perspective on insect olfactory systems. Prog Neurobiol. 2018; 161:23-60.

87. Vilpoux K, Sandeman R, Harzsch S. Early embryonic development of the central nervous system in the Australian crayfish and the Marbled crayfish (Marmorkrebs). Dev Genes Evol. 2006;216:209-23.

88. Minagawa M, Takashima F. Developmental changes in larval mouthparts and foregut in the red frog crab, Ranina ranina (Decapoda: Raninidae). Aquaculture. 1994;126:61-71.

89. Castejón D, Rotllant G, Ribes E, Durfort M, Guerao G. Foregut morphology and ontogeny of the spider crab Maja brachydactyla (Brachyura, Majoidea, Majidae). J Morphol. 2015;276:1109-22.

90. Abrunhosa FA, Simith DJ, Monteiro JR, Souza Junior AND, Oliva PA. Development and functional morphology of the larval foregut of two brachyuran species from Northern Brazil. An Acad Bras Ciênc. 2011;83:1269-78.

91. Abrunhosa FA, Melo MA, Abrunhosa JP. Development and functional morphology of the foregut of larvae and postlarva of Ucides cordatus (Decapoda, Ocypodidae). Nauplius. 2003;11:37-43.

92. Castejón D, Ribes E, Durfort M, Rotllant G, Guerao G. Foregut morphology and ontogeny of the mud crab Dyspanopeus sayi (Smith, 1869) (Decapoda Brachyura, Panopeidae). Arthropod Struct Dev. 2015;44:33-41.

93. Melo MA, Abrunhosa F, Sampaio I. The morphology of the foregut of larvae and postlarva of Sesarma curacaoense De Man, 1892: a species with facultative lecithotrophy during larval development. Acta amazonica. 2006; 36:375-80.

94. Al-Mohanna SY, Nott JA, Lane DJW. Mitotic E-and secretory F-cells in the hepatopancreas of the shrimp Penaeus semisulcatus (Crustacea: Decapoda). J Mar Biol Assoc UK. 1985;65:901-10.

95. Al-Mohanna SY, Nott JA. B-cells and digestion in the hepatopancreas of Penaeus semisulcatus (Crustacea: Decapoda). J Mar Biol Assoc UK. 1986;66: 403-14.
96. Abrunhosa FA, Kittaka J. Functional morphology of mouthparts and foregut of the last zoea, glaucothoe and first juvenile of the King Crabs Paralithodes camtschaticus, P. brevipes and P. platypus. Fisheries Science. 1997:63:923-30.

97. Biesiot PM, McDowell JE. Midgut-gland development during early lifehistory stages of the American lobster Homarus americanus. J Crustac Biol. 1995;15:679-85.

98. Anger K, Storch V, Anger V, Capuzzo JM. Effects of starvation on moult cycle and hepatopancreas of stage I lobster (Homarus americanus) larvae. Helgoländer Meeresunters. 1985;39:107-16.

99. Daniel RJ. The abdominal muscles of the shore crab (Carcinus maenas) and of the zoea and megalopa stages. Proc Trans Liverpool Biol Soc. 1931;45:50-6.

100. Gonor SL, Gonor JJ. Feeding, cleaning, and swimming behaviour in larval stages of porcellanid crabs (Crustacea: Anomura). Fish Bull. 1973;71:225-34.

101. Wirkner CS, Richter S. Circulatory system and respiration. In: Watling L, Thiel M, editors. Natural History of Crustacea. Vol 1: Functional Morphology and Diversity. Oxford: Oxford University Press; 2013. p. 376-412.

102. Spicer Jl, Morritt D. Ontogenic Changes in Cardic Function in Crustaceans. Comp Biochem Physiol. 1996;114:81-9.

103. McMahon BR, Tanaka K, Doyle JE, Chu KH. A change of heart: cardiovascular development in the shrimp Metapenaeus ensis. Comp Biochem Physiol. 2002;133:577-87.

104. McMahon BR, Burnett LE. The crustacean open circulatory system: a reexamination. Physiol Zool. 1990;63:35-71.

105. Felgenhauer BE. Internal Anatomy of the Decapoda: an overview. In: Harrison FW, Humus AG, editors. Microscopic anatomy of invertebrates Vol :10. New York: Wiley-Liss; 1992. p. 45-75.

106. Taylor HH, Taylor EW. Gills and Lunges: Exchange of Gases and lons. In: Harrison FW, Humus AG, editors. Microscopic anatomy of invertebrates Vol 10. New York: Wiley-Liss; 1992. p. 203-95.

107. Pequeux A. Osmotic regulation in crustaceans. J Crust Biol. 1995;15:1-60.

108. Khodabandeh S, Charmantier G, Charmantier-Daures M. Immunolocalization of $\mathrm{Na}+, \mathrm{K}+-\mathrm{ATP}$ ase in Osmoregulatory Organs During the Embryonic and Post-Embryonic Development of the Lobster Homarus Gammarus. J Crust Biol. 2006;26:515-23

109. Zeng C, Naylor E. Endogenous tidal rhythms of vertical migration in field collected zoea-1 larvae of the shore crab Carcinus maenas: implications for ebb tide offshore dispersal. Mar Ecol Prog Ser. 1996:71-82.

110. Zeng C, Naylor E. Synchronization of endogenous tidal vertical migration rhythms in laboratory-hatched larvae of the crab Carcinus maenas. J Exp Mar Biol Ecol. 1996;198:269-89.

111. Zeng C, Naylor E. Occurrence in coastal waters and endogenous tidal swimming rhythms of late megalopae of the shore crab Carcinus maenas: implications for onshore recruitment. Mar Ecol Prog Ser. 1996:69-79.

112. Queiroga H, Moksnes PO, Meireles S. Vertical migration behaviour in the larvae of the shore crab Carcinus maenas from a microtidal system (Gullmarsfjord, Sweden). Mar Ecol Prog Ser. 2002;237:195-207.

113. Moksnes PO, Corell H, Tryman K, Hordoir R, Jonsson PR. Larval behaviour and dispersal mechanisms in shore crab larvae (Carcinus maenas): Local adaptations to different tidal environments? Limnol Oceanogr. 2014;59:588-602.

114. Hallberg E, Skog M. Chemosensory sensilla in crustaceans. In: Breithauot T, Thiel M, editors. Chemical Communication in Crustaceans. New York: Springer; 2011. p. 103-21.

115. Laverack MS. External sensors and the dorsal organ of crustacea. In: Wiese K Krenz WD, Tautz J, Reichert H, Mulloney B, editors. Frontiers in Crustacean Neurobiology. Advances in Life Sciences. Basel: Birkhäuser; 1990. p. 90-6.

116. Martin JW, Laverack MS. On the distribution of the crustacean dorsal organ. Acta Zoologica. 1992;73:357-68.

117. Rudy Lerosey-Aubril R, Meyer R. The sensory dorsal organs of crustaceans. Biol Rev. 2013;88:406-26.

118. Sandeman DC, Okajima A. Statocyst-induced eye movements in the crab Scylla serrata: I. the sensory input from the statocyst. J Exp Biol. 1972;57:187-204.

119. Fraser PJ, Macdonald AG. Crab hydrostatic pressure sensors. Nature. 1994; 371:383.

120. Sekiguchi H, Terazawa T. Statocyst of Jasus edwardsii pueruli (Crustacea, Palinuridae), with a review of crustacean statocysts. Mar Freshwater Res. 1997:48:715-20.

121. Fraser PJ, Takahata PM. Statocysts and statocyst control of motor pathways in crayfish and crabs. In: Wiese K, editor. Crustacean Experimental Systems in Neurobiology. Berlin, Heidelberg: Springer; 2002. p. 89-108. 
122. Lovell JM, Findlay MM, Moate RM, Yan HY. The hearing abilities of the prawn Palaemon serratus. Comp Biochem Physiol A Mol Integr Physiol. 2005; 140:89-100.

123. Lang $D$, Yonge $C M$. The function of the tegumental glands in the statocyst of Homarus vulgaris. J Mar Biol Assoc U K. 1935;20:333-9.

124. Harzsch S, Sandman DC, Chaigneau J. Morphology and development of the central nervous system. In: Forest J, von Vaupel Klein JC, editors. Treatise on Zoology-Anatomy, Taxonomy, Biology. The Crustacea. Vol.3.: Leiden, Brill; 2012. p. 9-236.

125. Sullivan JM, Herberholz J. Structure of the nervous system: general design and gross anatomy. In: Watling L, Thiel M, editors. The Natural History of Crustacea. Vol. 1: Functional Morphology and Diversity. Oxford: Oxford University Press; 2013. p. 451-84.

126. Sandeman D, Kenning M, Harzsch S. Adaptive trends in malacostracan brain form and function related to behaviour. In: Derby CD, Thiel M, editors. The Natural History of Crustacea. Vol. 3: Nervous Systems and Their Control of Behaviour. Oxford: Oxford University Press; 2014. p. 11-48.

127. Schmidt M. Malacostraca. In: Schmidt-Rhaesa A, Harzsch S, Purschke G, editors. Structure and Evolution of Invertebrate Nervous Systems. Oxford: Oxford University Press; 2016. p. 529-82.

128. Krieger J, Sombke A, Seefluth F, Kenning M, Hansson BS, Harzsch S. Comparative brain architecture of the European shore crab Carcinus maenas (Brachyura) and the common hermit crab Pagurus bernhardus (Anomura) with notes on other marine hermit crabs. Cell Tissue Res. 2012;348:47-69.

129. Charmantier G, Charmantier-Daures M. Endocrine and neuroendocrine regulations in embryos and larvae of crustaceans. Invertebr Reprod Dev. 1998:33:273-87.

130. Webster SG, Dircksen H. Putative molt-inhibiting hormone in larvae of the shore crab Carcinus maenas L.: an immunocytochemical approach. Biol Bull. 1991;180:65-71.

131. Chung JS, Webster SG. Expression and release patterns of neuropeptides during embryonic development and hatching of the green shore crab, Carcinus maenas. Development. 2004;131:4751-61.

132. McConaugha JR. Identification of the Y-organ in the larval stages of the crab, Cancer anthonyi Rathbun. J Morphol. 1980;164:83-8.

133. Haug C, Rötzer MA. The ontogeny of Limulus polyphemus (Xiphosura s. str. Euchelicerata) revised: looking under the "skin". Dev Genes Evol. 2018;228: 49-61.

134. Sombke A, Lipke E, Michalik P, Uhl G, Harzsch S. Potential and limitations of X-Ray micro-computed tomography in arthropod neuroanatomy: A methodological and comparative survey. J Comp Neurol. 2015;523:1281-95.

135. Henne S, Friedrich F, Hammel J, Sombke A, Schmidt-Rhaesa A. Reconstructing the anterior part of the nervous system of Gordius aquaticus (Nematomorpha, Cycloneuralia) by a multi-methodological approach. J Morphol. 2017;278:106-18.

136. Holländer $\mathrm{H}$, Vaaland JL. A reliable staining method for semi-thin sections in experimental neuroanatomy. Brain Res. 1968;10:120-6.

137. Jantrarotai P, Srakaew N, Sawanyatiputi A. Histological study on the development of digestive system in zoeal stages of mud crab (Scylla olivacea). Kasetsart J (Nat Sci). 2005;39:666-71.

138. Li F, Li S. Comparative study on the development of gastric mill of the larvae of Scylla serrata. Mar Sci. 1995;5:38-41.

139. Li FH, Li SJ. Studies on the hepatopancreas of larval Scylla serrata. Oceanol Limnol Sin. 1998:29:33-8.

140. Lumasag GJ, Quinitio ET, Aguilar RO, Baldevarona RB, Saclauso CA. Ontogeny of feeding apparatus and foregut of mud crab Scylla serrata Forsskål larvae. Aquaculture Res. 2007;38:1500-11.

141. Sasaki GC, McDowell Capuzzo J, Biesiot P (1986) Nutritional and bioenergetic considerations in the development of the American lobster Homarus americanus. Can J Fish Aquat Sci 43:2311-2319

142. Nishida S, Quigley BD, Booth JD, Nemoto T, Kittaka J. Comparative morphology of the mouthparts and foregut of the final-stage phyllosoma, puerulus, and postpuerulus of the rock lobster Jasus edwardsii (Decapoda: Palinuridae). J Crustacean Biol. 1990;10:293-305.

143. Batel A, Melzer RR, Anger K, Geiselbrecht $H$. Heterochrony in mandible development - A comparative SEM study on zoea larvae of two carideans (Decapoda). J. Morph. 2014;275:1258-72.

144. Felder JM, Felder DL, Hand SC. Ontogeny of osmoregulation in the estuarine ghost shrimp Callianassa jamaicense var. louisianensis Schmitt (Decapoda, Thalassinidea). J Exp Mar Biol Ecol. 1986;99:91-105.
145. Pham D, Charmantier G, Boulo V, Wabete N, Ansquer D, Dauga C, Grousset $E$, Labreuche $Y$, Charmantier-Daures M. Ontogeny of osmoregulation in the Pacific blue shrimp, Litopenaeus stylirostris (Decapoda, Penaeidae): Deciphering the role of the Na+/K+-ATPase. Comparative Biochemistry and Physiology Part B: Biochemistry and Molecular Biology. 2016;196-197:27-37.

146. Freeman JA. The Crustacean Epidermis During Larval Development. In: Horst MN, Freeman JA, editors. The Crustacean Integument. Morphology and Biochemistry. Boca Raton: CRC Press; 1993. p. 193-219.

147. Cronin TW, Marshall NJ, Caldwell RL, Pales D. Compound eyes and ocular pigments of crustacean larvae (Stomatopoda and Decapoda, Brachyura). Mar Fresh Behav Physiol. 1995;26:219-31.

148. Charpentier CL, Cohen JH. Chemical cues from fish heighten visual sensitivity in larval crabs through changes in photoreceptor structure and function. J Exp Biol. 2015;218:3381-90.

149. Fincham AA. Ontogeny of anomuran eyes. Symp Zool Soc Lond. 1988;59:123-55.

150. Meyer-Rochow VB. Larval and adult eyes of the western rock lobster (Panulirus longipes). Cell Tissue Res. 1975;162:439-57.

151. Hafner GS, Tokarski TR. Morphogenesis and pattern formation in the retina of the crayfish Procambarus clarkii. Cell Tissue Res. 1998;293:535-50.

152. Sandeman R, Sandeman D. Development and Identified Neural Systems in the Crayfish Brain. In: Wiese K, Krenz WD, Tautz J, Reichert H, Mulloney B, editors. Frontiers in Crustacean Neurobiology. Advances in Life Sciences. Basel: Birkhäuser; 1990. p. 498-508.

153. Gorgels-Kallen JL, Meij JT. Immunocytochemical study of the hyperglycemic hormone $(\mathrm{CHH})$-producing system in the eyestalk of the crayfish Astacus leptodactylus during larval and postlarval development. J Morphol. 1985;183: 155-63.

154. Helluy S, Sandeman R, Beltz B, Sandeman D. Comparative brain ontogeny of the crayfish and clawed lobster: implications of direct and larval development. J Comp Neurol. 1993;335:343-54.

155. Foa LC, Cooke IR. The ontogeny of GABA-and glutamate-like immunoreactivity in the embryonic Australian freshwater crayfish, Cherax destructor. Dev Brain Res. 1998;107:33-42.

156. Beltz BS, Pontes M, Helluy SM, Kravitz EA. Patterns of appearance of serotonin and proctolin immunoreactivities in the developing nervous system of the American lobster. Dev Neurobiol. 1990;21:521-42.

157. Beltz BS, Helluy SM, Ruchhoeft ML, Gammill LS. Aspects of the embryology and neural development of the American lobster. J Exp ZoolA Ecol Genet Physiol. 1992;261:288-97.

158. Harzsch S. Evolution of identified arthropod neurons: the serotonergic system in relation to engrailed-expressing cells in the embryonic ventral nerve cord of the American lobster Homarus americanus Milne Edwards, 1873 (Malacostraca, Pleocyemata, Homarida). Dev Biol. 2003;258:44-56.

159. Cournil I, Casasnovas B, Helluy SM, Beltz BS. Dopamine in the lobster Homarus gammarus: II. Dopamine-immunoreactive neurons and development of the nervous system. J Comp Neurol. 1995;362:1-16.

160. Schneider H, Budhiraja P, Walter I, Beltz BS, Peckol E, Kravitz EA. Developmental expression of the octopamine phenotype in lobsters, Homarus americanus. J Comp Neurol. 1996;371:3-14.

161. Scholz NL, Chang ES, Graubard K, Truman JW. The NO/CGMP pathway and the development of neural networks in postembryonic lobsters. J Neurobiol. 1998:34:208-26.

162. Benton JL, Sandeman DC, Beltz BS. Nitric oxide in the crustacean brain: regulation of neurogenesis and morphogenesis in the developing olfactory pathway. Dev Dyn. 2007;236:3047-60.

163. Harzsch S, Dircksen H, Beltz BS. Development of pigment-dispersing hormone-immunoreactive neurons in the American lobster: homology to the insect circadian pacemaker system? Cell Tissue Res. 2009;335:417-29.

164. Pulver SR, Marder E. Neuromodulatory complement of the pericardial organs in the embryonic lobster, Homarus americanus. J Comp Neurol. 2002:451:79-90

165. Rotllant G, Kleijn DD, Charmantier-Daures M, Charmantier G, Herp FV. Localization of crustacean hyperglycemic hormone $(\mathrm{CHH})$ and gonadinhibiting hormone $(\mathrm{GIH})$ in the eyestalk of Homarus gammarus larvae by immunocytochemistry and in situ hybridization. Cell Tissue Res. 1993:271: 507-12.

166. Zieger E, Bräunig P, Harzsch S. A developmental study of serotoninimmunoreactive neurons in the embryonic brain of the Marbled Crayfish and the Migratory Locust: evidence for a homologous protocerebral group of neurons. Arthropod Struct Dev. 2013;42:507-20. 
167. Rieger V, Harzsch S. Embryonic development of the histaminergic system in the ventral nerve cord of the Marbled Crayfish (Marmorkrebs). Tissue Cell. 2008;40:113-26.

168. McLaughlin PA. Comparative Morphology. In: Mantel LH, editor. The Biology of Crustacea Vol. 5: Internal Anatomy and Physiological Regulation. New York: Academic Press; 1983. p. 1-53.

169. Bell TA, Lightner DV. A handbook of normal penaeid shrimp histology. In: Bell TA, Lightner. Baton Rouge: World Aquaculture Society; 1988.

170. Forest J, editor. Traité de Zoologie, Anatomie, Systématique, Biologie, Tome VII Crustacés, Fascicule 1 Morphologie, Physiologie, Reproduction, Systématique. Paris: Masson; 1994

171. Vogt G. Functional anatomy. In: Holdich DM, editor. Biology of freshwater crayfish. Oxford: Blackwell Science; 2002. p. 53-151.

172. Factor JR. The digestive system. In: Factor JR, editor. Biology of the Lobster Homarus americanus. San Diego: Academic Press; 1995. p. 395-440.

173. Brösing A. Recent developments on the morphology of the brachyuran foregut ossicles and gastric teeth. Zootaxa. 2010;2510:1-44.

174. Watling $L$. Feeding and digestive system. In: Watling $L$, Thiel $M$, editors. The Natural History of Crustacea. Vol. 1: Functional Morphology and Diversity. Oxford: Oxford University Press; 2013. p. 237-61.

175. Saborowski R. Nutrition and digestion. In: Chang ES, Thiel M, editors. The Natural History of Crustacea. Vol. 4: Physiology. New York: Oxford University Press; 2015. p. 285-319.

176. McLay CL, Becker C. Reproduction in Brachyura. In: Castro P, Davie PJF, Guinot D, Schram FR, von Vaupel Klein JC, editors. Treatise on ZoologyAnatomy, Taxonomy, Biology. The Crustacea, Vol.9, part C-I, Decapoda: Brachyura. Leiden, Boston: Brill; 2015. p. 185-244.

177. Martin GG, Hose JE. Vascular elements and blood (hemolymph). In: Harrison FW, Humes AG, editors. Microscopic anatomy of invertebrates. Vol. 10, Decapod Crustacea. New York: Wiley-Liss; 1992. p. 117-46.

178. Martin GG, Hose JE. Circulation, the blood,and disease. In: Factor JR, editor Biology of the Lobster Homarus americanus. San Diego: Academic Press; 1995. p. 465-96.

179. Söderhäll K, Söderhäll I. Immune reactions. In: Holdich DM, editor. Biology of freshwater crayfish. Oxford: Blackwell Science; 2001. p. 439-64.

180. Lin X, Söderhäll I. Crustacean hematopoiesis and astakine cytokines. Bloo. 2011;117:6417-24.

181. Wirkner CS, Tögel M, Pass G. The arthropod circulatory system. In: Minelli A, Boxshall G, Fusco G, editors. Arthropod Biology and Evolution - Molecules Development, Morphology. Heidelberg: Springer; 2013. p. 343-91.

182. McGaw IJ, Reiber CL. Circulatory physiology. In: Chang ES, Thiel M, editors. The Natural History of Crustacea. Vol. 4: Physiology. New York: Oxford University Press; 2015. p. 199-248.

183. Terwilliger NB. Oxygen transport proteins in Crustacea: hemocyanin and hemoglobin. In: Chang ES, Thiel M, editors. The Natural History of Crustacea. Vol. 4: Physiology. New York: Oxford University Press; 2015. p. 359-90.

184. Söderhäll I. Crustacean hematopoiesis. Dev Comp Immunol. 2016;58:129-41.

185. Mantel LH, Farmer LL. Osmotic and ionic regulation. In: Mantel LH, editor. The Biology of Crustacea. Vol. 5: Internal anatomy and physiological regulation. New York: Academic Press; 1983. p. 54-162.

186. McMahon BR, Wilkens JL. Ventilation, perfusion and oxygen uptake. In: Mantel LH, editor. The Biology of Crustacea. Vol. 5: Internal anatomy and physiological regulation. New York: Academic Press; 1983. p. 290-372

187. McMahon BR. The physiology of gas exchange, circulation, ion regulation, and nitrogenous excretion: an integrative approach. In: Factor JR, editor. Biology of the Lobster Homarus americanus. San Diego: Academic Press; 1995. p. 497-518.

188. Charmantier G, Charmantier-Daures M, Towle D. Osmotic and ionic regulation in aquatic arthropods. In: Evans DH, editor. Osmotic and Ionic Regulation. Cells and Animals, vol. 2009. Boca Raton, FL/New York, NY/ Oxford, UK: CRC Press; 2009. p. 165-230.

189. Cooke IM, Sullivan RE. Hormones and neurosecretion. In: Atwood HL, Sandeman DC, editors. The Biology of Crustacea. Vol. 3: Neurobiology: structure and function. New York: Academic Press; 1982. p. 206-91.

190. Fingerman M. Glands and secretion. In: Harrison FW, Humes AG, editors. Microscopic anatomy of invertebrates. Vol. 10, Decapod Crustacea. New York: Wiley-Liss; 1992. p. 345-94.

191. Webster S. Endocrinology of molting. In: Chang ES, Thiel M, editors. The Natural History of Crustacea. Vol. 4: Physiology. New York: Oxford University Press; 2015. p. 1-35.
192. Webster S. Endocrinology of metabolism and water balance. In: Chang ES, Thiel M, editors. The Natural History of Crustacea. Vol. 4: Physiology. New York: Oxford University Press; 2015. p. 36-68.

193. Felgenhauer BE. External anatomy and integumentary structures. In: Harrison FW, Humes AG, editors. Microscopic anatomy of invertebrates. Vol. 10, Decapod Crustacea. New York: Wiley-Liss; 1992. p. 7-44.

194. Horst MN, Freeman JA, editors. The crustacean integument. Morphology and biochemistry. Boca Raton: CRC Press; 1993.

195. Dillaman R, Roer R, Shafer T, Modla S. The crustacean integument: structure and function. In: Watling $L$, Thiel M, editors. The Natural History of Crustacea. Vol. 1: Functional Morphology and Diversity. Oxford: Oxford University Press; 2013. p. 140-65.

196. Garm A, Watling L. The crustacean integument: setae, setules and other ornamentation. In: Watling L, Thiel M, editors. The Natural History of Crustacea. Vol. 1: Functional Morphology and Diversity. Oxford: Oxford University Press; 2013. p. 167-98.

197. McNamara JC, Milograna SR. Adaptive color change and the molecular endocrinology of pigment translocation in crustacean chromatophores. In: Chang ES, Thiel M, editors. The Natural History of Crustacea. Vol. 4: Physiology. New York: Oxford University Press; 2015. p. 68-102.

198. Mellon DF Jr. Connective tissue and supporting structures. In: Harrison FW, Humes AG, editors. Microscopic anatomy of invertebrates. Vol. 10, Decapod Crustacea. New York: Wiley-Liss; 1992. p. 77-116.

199. Govind CK, Atwood HL. Organization of neuromuscular systems. In: Atwood HL, Sandeman DC, editors. The Biology of Crustacea. Vol. 3: Neurobiology: structure and function. New York: Academic Press; 1982. p. 63-104.

200. Chapple WD. Muscles. In: Atwood HL, Sandeman DC, editors. The Biology of Crustacea. Vol. 3: Neurobiology: structure and function. New York: Academic Press; 1982. p. 152-84.

201. Govind CK. Muscles and their innervation. In: Factor JR, editor. Biology of the Lobster Homarus americanus. San Diego: Academic Press; 1995. p. 291-312.

202. Atwood H. Peripheral components of crustacean motor systems. In: Derby CD, Thiel M, editors. The Natural History of Crustacea. Vol. 3: Nervous Systems and Their Control of Behaviour. Oxford: Oxford University Press; 2014. p. 85-113.

203. Medler S, Mykles DL. Muscle structure, fiber types, and physiology. In: Chang ES, Thiel M, editors. The Natural History of Crustacea. Vol. 4: Physiology. New York: Oxford University Press; 2015. p. 103-33.

204. Mykles DL, Medler S. Skeletal muscle differentiation, growth and plasticity. In: Chang ES, Thiel M, editors. The Natural History of Crustacea. Vol. 4: Physiology. New York: Oxford University Press; 2015. p. 134-67.

205. Strausfeld NJ, Nässel DR. Neuroarchitectures serving compound eyes of Crustacea and insects. In: Land MF, Autrum H, editors. Handbook of sensory physiology. New York: Springer; 1981.

206. Shaw SR, Stowe S. Photoreception. In: Atwood HL, Sandeman DC, editors The Biology of Crustacea. Vol. 3: Neurobiology: structure and function. New York: Academic Press; 1982. p. 292-368.

207. Stavenga DG, Hardie RC, editors. Facets of Vision. Berlin, Heidelberg: Springer; 1989.

208. Warrant E, Nilsson DE, editors. Invertebrate Vision. Cambridge: Cambridge University Press; 2006

209. Glantz R. Visual systems of crustaceans. In: Derby CD, Thiel M, editors. The Natural History of Crustacea. Vol. 3: Nervous Systems and Their Control of Behaviour. Oxford: Oxford University Press; 2014. p. 206-34.

210. Ache BW. Chemoreception and thermoreception. In: Atwood HL, Sandeman DC, editors. The Biology of Crustacea. Vol. 3: Neurobiology: structure and function. New York: Academic Press; 1982. p. 369-98.

211. Bush BMH, Laverack MS. Mechanoreception. In: Atwood HL, Sandeman DC, editors. The Biology of Crustacea. Vol. 3: Neurobiology: structure and function. New York: Academic Press; 1982. p. 399-468.

212. Govind CK. Nervous system. In: Harrison FW, Humes AG, editors. Microscopic anatomy of invertebrates. Vol. 10, Decapod Crustacea. New York: Wiley-Liss; 1992. p. 395-438.

213. Atema J, Voigt R. Behaviour and sensory biology. In: Factor JR, editor. Biology of the Lobster Homarus americanus. San Diego: Academic Press 1995. p. 313-48.

214. Breithaupt T, Thiel M, editors. Chemical Communication in Crustaceans. New York: Springer; 2011.

215. Boxshall G, Jaume D. Antennules and antennae in the Crustacea. In: Watling L. Thiel M editors. The Natural History of Crustacea. Vol. 1: Functional Morphology and Diversity. Oxford: Oxford University Press; 2013. p. 199-237. 
216. Derby CD, Weissburg MJ. The chemical senses and chemosensory ecology of Crustaceans. In: Derby CD, Thiel M, editors. The Natural History of Crustacea. Vol. 3: Nervous Systems and Their Control of Behaviour. Oxford: Oxford University Press; 2014. p. 263-93.

217. Mellon D. Smelling, feeling, tasting and touching: behavioural and neural integration of antennular chemosensory and mechanosensory inputs in the crayfish. J Exp Biol. 2012;215:2163-72.

218. Mellon D. Sensory systems of crustaceans. In: Derby CD, Thiel M, editors. The Natural History of Crustacea. Vol. 3: Nervous Systems and Their Control of Behaviour. Oxford: Oxford University Press; 2014. p. 49-84.

219. Lenz $P$, Hartline DK. Mechanoreception in crustaceans of the pelagic realm. In: Derby CD, Thiel M, editors. The Natural History of Crustacea. Vol. 3: Nervous Systems and Their Control of Behaviour. Oxford: Oxford University Press; 2014. p. 293-320.

220. Lohmann KL, Ernst DA. The geomagnetic sense of crustaceans and ist use in orientation and navigation. In: Derby CD, Thiel M, editors. The Natural History of Crustacea. Vol. 3: Nervous Systems and Their Control of Behaviour. Oxford: Oxford University Press; 2014. p. 321-36.

221. Sandeman DC. Organization of the central nervous system. In: Atwood HL, Sandeman DC, editors. The Biology of Crustacea. Vol. 3: Neurobiology: structure and function. New York: Academic Press; 1982. p. 1-62.

222. Sandeman DC, Sandeman RE, Derby CD, Schmidt M. Morphology of the brain of crayfish, crabs, and spiny lobsters: a common nomenclature for homologous structures. Biol Bull. 1992;183:304-26.

223. Strausfeld NJ. Arthropod Brains: Evolution, Functional Elegance, and Historical Significance. Cambridge: Belknap; 2012.

224. Loesel R, Wolf H, Kenning M, Harzsch S, Sombke A. Architectural Principles and evolution of the arthropod central nervous system. In: Minelli A Boxshall G, Fusco G, editors. Arthropod Biology and Evolution. Berlin, Heidelberg: Springer; 2013. p. 299-342.

225. Lopez Greco LS. Functional anatomy of the reproductive system. In: Watling L, Thiel M, editors. The Natural History of Crustacea. Vol. 1: Functional Morphology and Diversity. Oxford: Oxford University Press; 2013. p. 413-51.

226. Talbot P, Helluy S. Reproduction and Embryonic Development. In: Factor JR, editor. Biology of the Lobster Homarus americanus. San Diego: Academic Press; 1995. p. 177-216.

227. Krol RM, Hawkins WE, Overstret RM. Reproductive components. In: Harrison FW, Humes AG, editors. Microscopic anatomy of invertebrates. Vol. 10, Decapod Crustacea. New York: Wiley-Liss; 1992. p. 295-344.

\section{Ready to submit your research? Choose BMC and benefit from:}

- fast, convenient online submission

- thorough peer review by experienced researchers in your field

- rapid publication on acceptance

- support for research data, including large and complex data types

- gold Open Access which fosters wider collaboration and increased citations

- maximum visibility for your research: over $100 \mathrm{M}$ website views per year

At BMC, research is always in progress.

Learn more biomedcentral.com/submissions 